http://dx.doi.org/10.18778/8088-914-9

\title{
Legal methods \\ for combating \\ unemployment \\ among older people
}


畒 


\section{Legal methods}

for combating

\section{unemployment}

among older people

Magdalena Paluszkiewicz

Tatiana Wrocławska

Mirosław Włodarczyk 
Magdalena Paluszkiewicz, Mirosław Włodarczyk - University of Łódź

Faculty of Law and Administration, Department of Social Security Law and Social Policy 90-232 Łódź, 8/12 Kopcińskiego St

Tatiana Wrocławska - University of Łódź, Faculty of Law and Administration

Department of Labour Law, 90-232 Łódź, 8/12 Kopcińskiego St

\author{
REVIEWER \\ Daiva Petrylaite \\ INITIATING EDITOR \\ Monika Borowczyk \\ TYPESETTING \\ AGENT PR \\ TECHNICAL EDITOR \\ Leonora Wojciechowska \\ COVER DESIGN \\ Katarzyna Turkowska
}

Cover Image: @ Depositphotos.com/Ryhor

This publication has been developed as a part of the project "Model of legal instruments taken to combat unemployment among older people - legal analysis” („W poszukiwaniu modelu przeciwdziałania bezrobociu wśród osób starszych - analiza prawna"), financed by National

Science Centre (Poland), UMO-2013/09/B/HS5/04137

(C) Copyright by Authors, Łódź 2017

(c) Copyright for this edition by University of Łódź, Łódź 2017

Published by Łódź University Press

First edition. W.08242.17.0.K

Publisher's sheets 11.5; printing sheets 9.5

e-ISBN 978-83-8088-914-9

Łódź University Press

90-131 Łódź, 8 Lindleya St.

www.wydawnictwo.uni.lodz.pl

e-mail: ksiegarnia@uni.lodz.pl

phone. (42) 6655863 


\section{Contents}

1. Introduction 9

2. Legal measures for supporting the employment of older people in Belgium, Denmark, Germany and Hungary 13

2.1. Prohibition of discrimination on the grounds of older age 13

2.2. Employment costs for older workers 15

2.3. Working conditions for older workers 17

2.4. Improving the professional qualifications of older workers 20

2.5. Protection of employment sustainability 22

3. Legal measures to support reintegration of unemployed older people into the labour market in Belgium, Denmark, Germany and Hungary 26

3.1. Prohibition of discrimination in access to employment on the grounds of older age $\quad 26$

3.2. Subsidizing the employment of unemployed older persons 27

3.3. Vocational training of the older unemployed 32

3.4. Flexible forms of employing unemployed older people 33

3.5. Services offered to unemployed older people by public employment services $\quad 34$

4. Legal measures to mitigate the effects of unemployment in Belgium, Denmark, Germany and Hungary 38

5. An outline of the position of older people on the Polish labour market 40

6. Conclusions 53 


\section{Tatiana Wroctawska}

1. General introductory notes

2. Legal measures for supporting employment and return to work of older people in Lithuania, Czech Republic, Slovakia and Netherlands

2.1. The general remarks related to population ageing and active participation of older at the labour market

2.2. Legal regulations for supporting employment of older people

2.3. Prohibition of discrimination on the grounds of age

2.4. Active and passive legal measures related to combating unemployment among older people

2.5. Right to retirement pension and other benefits

2.6. Concluding remarks

3. Conclusions

\section{Part III}

\section{Mirostaw Włodarczyk}

Structural elements of the model of counteracting unemployment among older people 


\section{Preface}

This publication constitutes the final report of the research carried out in the years 2014-2017 within the framework of a research project financed by the Polish National Science Centre grant "W poszukiwaniu modelu przeciwdziałania bezrobociu wśród osób starszych - analiza prawna”, UMO-2013/09/09/B/HS5/04137. The main goal of the research project was an attempt to present a model set of initiatives and legal measures that should be taken in order to reduce the phenomenon of unemployment among older people. These investigations were to be based, and this was the case, on the examination of the legal regulations of selected European countries. The relevant regulations of Belgium, Czech Republic, Denmark, the Netherlands, Lithuania, Germany, Slovakia and Hungary were finally subjected to the research process. Polish legal solutions were also the subject of the research process. The scope of the study encompassed legal institutions which were used in a given country to reduce or eliminate unemployment among older people; where it was justified, general regulations concerning unemployment reduction were presented.

The aim of the research process was to gather knowledge about the activities of various legal institutions in the countries surveyed, which had an impact on the employment status of older people, as well as assessments concerning the impact of these institutions on the level of employment and unemployment of a designated group of entities. Such an approach made it possible to determine the adequacy of legal measures applied to the needs resulting from the current social and economic situation in which older people may have been involved. Therefore, research has not been limited to narrowly understood legal devices aimed at reducing unemployment among older people. These also included legal instruments that relate directly to employment and are implemented in relation to employment (the area of regulations concerning retention of employment - employment stabilization), as well as regulations defining rights of older people with regard 
to the process of finishing their professional career and leaving the labour market (old age pensions, disability pensions). Such a comprehensive analysis made it possible to show and highlight implications arising in the area of law, as well as social practice, between the three aforementioned areas of legal regulation: employment, unemployment and retirement - usually analysed in separate, independent studies.

The presented publication consists of three parts. The first two parts present the results of the research concerning the particular abovementioned countries. The first part was developed by Magdalena Paluszkiewicz and comprises the results of research concerning Hungary, Germany, Denmark and Belgium. In the final points, the Author presents a diagnosis of Polish legal practice in the examined scope and, in the conclusion, presents her own model approach to counteracting unemployment among older people. In the second part, Tatiana Wrocławska provides the results of research concerning the Czech Republic, Lithuania, Slovakia and the Netherlands; the final conclusions include a collective and comparative assessment of institutions existing in the surveyed countries. The third part of the study prepared by Mirosław Włodarczyk is of a different nature from the aforementioned, and aims at presenting the components of the model of counteracting unemployment among older people. The construction of this model consists of several tasks, which should be addressed to the national legislator. In turn, within each task, a number of legal institutions have been identified, which can be used to implement the objective derived from the name of that task. Both isolation of subsequent tasks, as well as the placement of these legal institutions within them, is the outcome of the knowledge gathered by the Authors of the first two parts of the publication. 


\section{Part I}

\section{Magdalena Paluszkiewicz}

\section{Introduction}

Some introductory remarks should be made before the analysis of the legal systems of selected countries in search of the measures needed to build a model for tackling the unemployment of older people in Poland. These are necessary in order to justify the choice of the analyzed issues.

The theory of economics indicates that long-term economic growth is a factor that has a major impact on the size of unemployment. Ignoring the divergence of views on the extent of state intervention in the market economy, ${ }^{1}$ it should be emphasized that state policy on unemployment is exclusively ancillary and that its impact is limited. ${ }^{2}$ Moreover, this policy is not homogeneous. Some actions are taken with respect to the macroeconomic economy, while others are limited to the labour market and yet others are targeted only at certain entities operating

1 As regards Poland, the legal basis for the interference is Article 20 of the Constitution of the Republic of Poland, O J. 1997 No. 78, item. 483 as amended it allows "corrective" state interference in the functioning of the market economy, which will allow for social justice, protection of a healthy social system and realization of social goals - L. Garlicki, M. Zubik, Komentarz do art. 20, [in:] Konstytucja Rzeczypospolitej Polskiej. Komentarz. Vol. I, ed. II. [online], Warszawa 2016, https://sip.lex.pl/\#/komentarz/587734548/531988, (accessed: 27.06.2017).

2 M. Kabaj, Strategie i programy przeciwdziałania bezrobociu. Studium porównawcze, Warszawa 1997, p. 68; E. Kwiatkowski, Bezrobocie. Podstawy teoretyczne, Warszawa 2014, p. 332; Z. Góral, M. Włodarczyk, Prawne problemy rynku pracy, [in:] H. Lewandowski (ed.), Polskie prawo w okresie transformacji w oświetleniu prawa wspólnotowego, Warszawa 1997, p. 153; M. Knapińska, Polityka rynku pracy w Polsce w latach 2000-2008, [in:] E. Kwiatkowski, L. Kucharski (eds.), Rynek pracy w Polsce - tendencje, uwarunkowania i polityka państwa, Łódź 2010, p. 261. 
there. ${ }^{3}$ The battle with unemployment includes, in particular, the creation of new jobs, the promotion of existing ones, the professional activation of the unemployed and the reduction of structural mismatches on the labour market. ${ }^{4}$ All measures targeted at certain elements of the economic system to counteract unemployment, reduce its size, and mitigate the effects of this phenomenon are referred to as umeployment prevention measures. ${ }^{5}$ Due to the degree of influence of these methods on production potential, they are traditionally divided into active and passive. ${ }^{6}$ Both active and passive measures limit the number of the unemployed. Active measures stimulate job creation (e.g. public works, loans for job creation), ${ }^{7}$ while passive ones serve to ensure transfers between the existing resources of professionally active and inactive people, in particular by setting retirement age limits, granting pre-retirement benefits and using flexible ways of working. ${ }^{8}$ The passive measures of labour market policies, which include various social benefits, especially unemployment benefits, ${ }^{9}$ play their role in mitigating the effects of unemployment.

The differentiation of methods to counteract unemployment is due to its variety of causes, as well as the heterogeneity of this phenomenon. Moreover, not all people affected by unemployment have equal chances to take up employment again, ${ }^{10}$ therefore, in certain cases it is necessary to apply specific, individualized measures to support the return to work. ${ }^{11}$ The confirmation of this observation is Art. 6 (2) of Convention No. 168 of the International Labour Organization of June $1^{\text {st }}, 1988$ on promoting employment and protection against unemployment, ${ }^{12}$ according to which it is appropriate to create measures to meet the needs of categories of people who have specific problems on the labour market. According to Art. 8 (1) of the Convention, those people include, in particular, older workers, and the resources are targeted through particular programmes to promote additional employment opportunities and help find and encourage employment.

Older people are a specific category on the labour market. Obstacles encountered by people in a disadvantaged position on the labour market are primarily removed by means provided under active labour market policy. ${ }^{13}$ It is worth emphasizing that labour market policy has the best effects on the reduction of frictional, short-term

3 E. Kwiatkowski, Bezrobocie..., p. 330.

4 E. Kwiatkowski, Bezrobocie..., pp. 330-332.

5 J. Bernais, Klasyfikacja metod i środków przeciwdziałania bezrobociu, "Rynek Pracy" 1996, no. 4, pp. 9-10.

6 J. Bernais, Klasyfikacja metod..., pp. 14-15; M. Knapińska, Polityka rynku..., p. 250 and the literature cited therein.

7 M. Kabaj, Strategie..., p. 66; J. Bernais, Klasyfikacja metod..., p. 11.

8 J. Bernais, Klasyfikacja metod..., pp. 11-12.

9 J. Bernais, Klasyfikacja metod..., p. 10.

10 Z. Góral, M. Włodarczyk, Prawne problemy rynku pracy, p. 151.

11 Cf. J. Bernais, Klasyfikacja metod..., pp. 15-16.

12 http://www.mop.pl/doc/html/konwencje/k168.html, (accessed: 27.06.2017).

13 E. Kwiatkowski, Bezrobocie..., pp. 328-329 and the literature cited therein. 
unemployment, whereas in the case of structural unemployment, i.e. long-term unemployment, it generates huge public expenditure and is characterized by low efficiency. ${ }^{14}$ It is also a policy that mainly affects labour supply; apart from subsidizing employment, it does not have the instruments for job creation. ${ }^{15}$ For these reasons, as well as for depreciation of violent economic phenomena, which generally cause unemployment, it is necessary to supplement the labour market policy with measures affecting its flexibility, ${ }^{16}$ especially such as deregulation, which increases the freedom of economic entities and restricts the regulation of employment relationships. ${ }^{17}$ Flexibility of employment is achievable through legal institutions, such as atypical forms of employment, working time, remuneration rules, rules for establishing and resolving employment. The literature, however, emphasizes that deregulation is not a sufficient mean to combat unemployment, ${ }^{18}$ and at the same time, its application is always linked to the limitation of social rights, which can lead to the destabilization of social harmony. ${ }^{19}$

The above findings affect the scope of further considerations. They focus on both active and passive labour market instruments to counteract older people's unemployment, as well as on elements of employment relationships that may affect flexibility or lack of employment when employing older workers. Due to the fact that older people are a disadvantaged category on the labour market due to considerable difficulty in reemployment, the first priority was to focus on the means to maintain their employment, and only then was an analysis of the solutions supporting re-employment performed. Social allowances which alleviate the effects of unemployment have also been analysed to the extent necessary. In their case, it is important to determine the strength of the incentive's function in the take up of employment. In the analysis, it was also necessary to define the concept of "a senior worker" or "older unemployed person". The conventional ending of professional activity is the reaching of retirement age, which is specifically established under the legislation of the countries surveyed. Greater problems arise when it comes to settling on the point at which the legislators perceive labour market participants as older, therefore, in addition to the specific legal regulations, the views presented in the literature on the subject are also taken into account.

The analysis is predominantly legal. Only the acquis of the economic sciences doctrine has been used, particularly as regards the effectiveness of active labour market policies, all the time aware of the limited cognitive value contained in the literature on e.g. the probability of employment or the employment rate at

14 M. Kabaj, Strategie..., p. 45; Z. Wiśniewski, Kierunki i skutki deregulacji rynku pracy w krajach Unii Europejskiej, Toruń 1999, p. 20.

15 Z. Wiśniewski, Kierunki..., p. 32.

16 E. Kwiatkowski, Bezrobocie..., p. 339.

17 Z. Wiśniewski, Kierunki..., p. 37.

18 Ibidem, p. 142.

19 E. Kwiatkowski, Bezrobocie..., p. 331; Z. Wiśniewski, Kierunki..., p. 142. 
the end of the labour market program. ${ }^{20}$ Studies include the above-mentioned legal measures under the laws of four countries: Hungary, Germany, Belgium and Denmark. Due to the limited scope of the study, the following considerations were restricted to the legal measures most frequently described in the literature on the subject, although the scope of legal analysis was broader. Conclusions based on the research will allow us to identify the implications of building a model that counteracts the unemployment of older people in Poland.

20 More details: R. Kisiel, S. Nowińska, Efektywność aktywnej polityki rynku pracy na tle doświadczeń międzynarodowych, "Polityka Społeczna” 2010, no. 5-6, passim. 


\section{Legal measures for supporting the employment of older people in Belgium, Denmark, Germany and Hungary}

\subsection{Prohibition of discrimination on the grounds of older age}

In all surveyed countries, there are similar standards for the protection against discrimination in employment as a result of the implementation of Framework Directive 2000/78/EC of the European Parliament and Council establishing a general framework for equal treatment in employment and occupation. ${ }^{1}$

In Hungary, the age-based equal treatment principle applies primarily to the Equal Treatment Act of December 22nd, 2003 and the promotion of equal opportunities, ${ }^{2}$ as well as the Hungarian Labour Code. ${ }^{3}$ Less favorable treatment is prohibited in particular when setting remuneration for work, working conditions, defining the rules for access to professional qualifications, and when terminating an employment contract. ${ }^{4}$ There are envisaged situations that allow for differential treatment on the grounds of age, e.g. when it is for a particular job, ${ }^{5}$ and also when it is aimed at equalizing the employment of the disadvantaged (so-called positive discrimination), while maintaining the rationality and proportionality of measures, specified in the detail conditions. ${ }^{6}$ In order to equalize the employment opportunities of specific categories of employees, appropriate provisions may be made, among others, within collective agreement. ${ }^{7}$ In addition, in the Hungarian Labour Code there is a provision according to which an employer intending to take measures to implement the principle of equal treatment or equalize employment opportunities should consult the workers' council. Actions should include, in particular, an analysis of the employment conditions of specific categories of workers, including, among others, those above 40 years of age, the structure of their remuneration, opportunities for career development and improvement of professional qualifications, and adjusting the workplace to the needs of a person with a physical impairment. ${ }^{8}$

$1 \quad$ O.J. L 303, 15.12.2000, pp. 16-22.

2 2003. évi CXXV. törvény az egyenlo bánásmódról és az esélyegyenloség elomozdításáról, Magyar Közlöny, 2003-12-28, No. 157, pp. 13044-13054.

3 2012. évi I. törvény a munka törvénykönyvéröl, Magyar Közlöny, 2012-01-6, vol. 2, pp. 257-316.

4 C. K. Lehoczky, Legal Instruments Guaranteeing Equal Treatment in the Wake of Accession to the European Union, [in:] K. Fazekas, A. Lovasz, A. Telegdy (eds.), The Hungarian Labour Market 2010. Review and Analysis, Budapest 2010, p. 71.

5 C. K. Lehoczky, Legal Instruments..., p. 78; I. Krisch, N. Kürti, Hungary, [in:] N. ten Bokum, T. Flanagan, R. Sands, R. von Steinau-Steinbrück (eds.), Age Discrimination Law in Europe, The Netherlands 2009, p. 159.

$6 \quad$ I. Krisch, N. Kürti, Hungary..., p. 166.

7 Ibidem.

8 I. Krisch, N. Kürti, Hungary..., p. 169. 
In Germany, the issue of equal treatment in employment is regulated by the General Equal Treatment Act of August $14^{\text {th }}, 2006^{9}$ (AGG), but also partially in the act on protection against unjustified termination of employment of August 10 ${ }^{\text {th }}, 1951$ (KSchG). ${ }^{10}$ The first of the indicated regulations refers to the phase of employment and the second to its termination. Employees who are not covered by the KSchG may be protected by the Civil Code. ${ }^{11}$ Discrimination is prohibited in particular as regards the shaping of employment conditions and access to vocational training. The general ban on age discrimination has exceptions. In particular, age can be the basis for differentiation, justified by the nature of the work performed or the conditions necessary for its proper performance. With regard to older workers, the need to promote their employment and ensure their protection may justify, in particular, the introduction of special conditions for access to employment and vocational training. It is also acceptable to use solutions specifically tailored to the needs of older workers, such as longer periods of notice, stronger protection against dismissal, additional leave and shift work prohibition, to prevent or compensate for deficiencies. ${ }^{12}$

In Denmark, anti-discrimination law was introduced by the act of May $24^{\text {th }}$, 1996 prohibiting discrimination on the labour market, ${ }^{13}$ through which national solutions have also been adapted to ILO Convention $111{ }^{14}$ Employers can not discriminate at the stage of access to employment, actual employment and its termination. However, age-related restrictions can be introduced in collective agreements if they do not constitute an infringement of the workers' rights at the level guaranteed by EU legislation. In particular, it is possible to establish stronger protection against discrimination. ${ }^{15}$ However, it is not permissible to pay employees differently

9 Allgemeines Gleichbehandlungsgesetz vom 14. August 2006 (BGBI. I S. 1897), das zuletzt durch Artikel 8 des Gesetzes vom 3. April 2013 (BGBI. I S. 610) geändert worden ist.

10 Kündigungsschutzgesetz in der Fassung der Bekanntmachung vom 25. August 1969 (BGBl. I S. 1317), das zuletzt durch Artikel 3 Absatz 2 des Gesetzes vom 20. April 2013 (BGBI. IS. 868) geändert worden ist.

11 Bürgerliches Gesetzbuch in der Fassung der Bekanntmachung vom 2. Januar 2002 (BGBI. I S. 42, 2909; 2003 I S.738), das durch Artikel 3 des Gesetzes vom 24. Mai 2016 (BGBI. I S. 1190) geändert worden ist; R. von Steinau-Steinrück, C. Vernuft, Germany, [in:] N. ten Bokum, T. Flanagan, R. Sands, R. von Steinau-Steinrück (eds.), Age Discrimination Law in Europe, The Netherlands 2009, pp. 131-135.

12 Ibidem; M. Paluszkiewicz, Wybrane środki prawne wspomagajace utrzymanie zatrudnienia przez pracowników starszych w Niemczech, „Studia Prawno-Ekonomiczne”, vol. Cl, pp. $117-118$ and the literature cited therein.

13 Bekendtgørelse af lov om forbud mod forskelsbehandling på arbejdsmarkedet m.v., LBK nr 1349 af 16/12/2008, https://www.lovtidende.dk/Forms/L0700.aspx?s31=10\&s2 1=lov+om+forbud+mod+forskelsbehandling+p\%c3\%a5+arbejdsmarkedet+m.v., (accessed: 28.07.2016).

14 S. Høeg Madsen, Denmark, [in:] N. ten Bokum, R. Sands, R. von Steinau-Steinrück (eds.), Age Discrimination Law in Europe, p. 77.

15 OECD, Ageing and Employment Policies: Denmark 2015: Working Better With Age, Paris 2015, p. 93. 
based on other factors than the type of work, its quantity and quality. An employee receiving lower remuneration based on age, has the right to seek parity. In addition, it is not permissible to include in a contract of employment that it may be terminated in connection with the retirement of an employee or that the employee is obliged to cease to work and to exercise his right to a pension. In this respect, the legal status was changed at the beginning of 2016, as a result of the judgment of the Court of Justice of the EU in Ingeniørforeningen i Danmark vs. Region Syddanmark. ${ }^{16}$

In Belgium, anti-discrimination legislation ${ }^{17}$ prohibits any employment behavior that can be classified as age discrimination. However, if in a particular case age constitutes a real and necessary condition for the performance of a given task, the shaping of the worker's situation on the basis of this criterion will be admissible. In addition, however, such a differentiation is required to be justified and the means to achieve it must be proportionate. ${ }^{18}$ It is also permissible to differentiate the situation of workers on the basis of age when it is objectively and reasonably justified by a legitimate objective, related in particular to employment policy, when the means for its implementation are appropriate and necessary. ${ }^{19}$ Protection is available during the phase of the employment relationship as well as at the time of its termination. In particular, the employee's age cannot be the sole criterion for determining remuneration. The provisions of employment contracts, collective agreements, as well as unilateral acts shaping the obligations of the employee that violate the prohibition of discrimination are null and void. ${ }^{20}$

\subsection{Employment costs for older workers}

In Hungary, employers generally do not bear higher costs for employing older workers as social contributions funded by the employer are the same regardless of the age of the employees. ${ }^{21}$ Higher costs associated with employing older workers may,

16 Judgment of the ECJ of 12 October 2010 in case C499/08, Collection of Judgments 2010 I-09343, more details: M. Paluszkiewicz, Wybrane środki prawne wspierajace zatrudnienie pracowników starszych w Danii, "Zeszyty Prawnicze UKSW" 2017, vol. 17.3, pp. 170-172 and literature provided there.

17 Loi tendant à lutter contre certaines formes de discrimination, Moniteur belge, 201206-05, n 192, pp. 31670-31677 et modifié plusieurs fois, http://www.ilo.org/dyn/ natlex/natlex4.detail?p_lang $=e n \& p \_i s n=90258 \& p \_c o u n t r y=B E L \& p \_c o u n t=3102 \& p$ classification=05\&p_classcount $=171$, (accessed: 008.04.2016).

18 Y. Stox, Belgium, [in:] N. ten Bokum, R. Sands, R. von Steinau-Steinrück (eds.), Age Discrimination Law in Europe, p. 23.

19 Y. Stox, Belgium..., p. 23.

20 More details: M. Paluszkiewicz, Wybrane środki prawne wspomagajace utrzymanie zatrudnienia pracowników starszych w Belgii, "Praca i Zabezpieczenie Społeczne” 2016, no. 10 , p. 10.

21 I. Krisch, N. Kürti, Hungary..., p. 162. 
however, be generated by the legal regulation of remuneration for annual leave. This is due to the fact that the amount of annual leave depends directly on the age of the employee and rises proportionately. Increased costs may also be incurred by the employer in connection with the dismissal of an older worker, which has the effect of stabilizing his/her employment. The employer may be willing to dismiss younger employee, which entails lower costs. Regulation on the minimum wage also creates possibilities for cost reduction. This may be carried out taking into account factors such as, in particular, occupational specific requirements, national labour market indicators, the state of the national economy, and the unique requirements of certain economic sectors and geographical areas in terms of employment. In practice, two rates are set, depending on the level of education of the employee and his professional experience. ${ }^{22}$

In Germany, it is pointed out that the increase in the cost of employing older workers is indirectly influenced by remuneration systems linked to professional experience or occupational experience. ${ }^{23}$ Abandoning these criteria during the formation of a remuneration system is a way of retaining older employees' employment rates. In the industrial sector, every third employer makes remuneration dependent on the in-company occupational experience, which increases the employment costs of older workers compared to younger ones. It is proposed to include such provisions in wage agreements that make remuneration dependent on the skill of the employee. ${ }^{24}$

In Denmark, financial support for employers is possible in the case of the hiring of a worker who is at hightened risk of absenteeism due to poor health. This consists of reimbursing the cost of paid remuneration for part of the period of incapacity for work. ${ }^{25}$ In Belgium, it is possible to subsidize part of the cost of employing older workers in order to compensate for any decrease in their productivity. 26

22 J. Kollo, Minimum wage regulation, [in:] K. Fazekas, A. Scharle (eds.), From Pensions to Public Works. Hungarian Employment Policy from 1990 to 2010, Budapest 2012, p. 141; Z. Cseres-Gergely, K. Varadovics, Labour Market Policy Interventions September 2012January 2014, [in:] K. Fazekas, L. Neumann (eds.), The Hungarian Labour Market 2014, Budapest 2014, p. 237.

23 R. von Steinau-Steinrück, C. Vernuft, Germany..., p. 131; T. Zwick, The Employment Consequences of Seniority Wages, "ZEW Discussion Paper” no. 08-039, p. 18; J. S. Heywood, U. Jirjahn, The German Labor Market for Older Workers in Comparative Perspective, Iniversität Trier, "Research Paper in Economics" 2015, no. 2, pp. 359-360.

24 Bundesagentur für Arbeit: Host Country PES Issues Paper, Peer Review 'PES and Older Workers', The European Commission Mutual Learning Programme for Public Employment Services, European Commission March 2012, p. 13.

25 More details: M. Paluszkiewicz, Wybrane środki prawne wspierajqce zatrudnienie pracowników starszych w Danii, pp. 177-178 and literature provided there.

26 M. Dejemeppe, C. Smith, B. Van der Linden, Did the Intergenerational Solidarity Pact Increase the Employment Rate of Older Workers in Belgium? A Macro-Econometrics Evaluation, "IZA Discussion Paper" 2015, June, no. 9115, p. 5; A. Albanese, B. Cockx, Permanent Wage Cost Subsidies for Older Workers: An Effective Tool for Increase Working Time and Postponing Early Retirement?, "IZA Discussion Paper” 2015, April, no. 8988, 


\subsection{Working conditions for older workers}

Improving the health of older workers is one of the most important factors in maintaining their employment. In Hungary, health programs do not relate to employment but generally to the protection of this asset and the health system itself. Their impact on employment issues are therefore only indirect. 27 The workload may be alleviated through part-time employment. At present, part-time employment is not widespread among older workers, and it occurs to a small extent in the education and health sector. ${ }^{28}$ One solutions addressed at older workers is through holiday entitlement. The annual leave per calendar year is generally 20 working days. However, employees are also entitled to additional days, the number of which is directly related to their age. In particular, workers who are 45 years of age are entitled to an additional 10 days of annual leave. In addition, workers who have lost at least $50 \%$ of their ability to work are entitled to an additional 5 days of annual leave. ${ }^{29}$

Another example of employment conditions tailored to the needs of older workers comes from Germany. The Act of September $3^{\text {rd }}, 1953$ on working time 30 (ArbGG) allows for the regulating of working time through autonomous labour law. In particular, industry-wide agreements set separate daily and weekly standards for working time, night shifts or number of days of annual leave. ${ }^{31}$ The reduction of the working hours of older workers has a similar goal, more often referred to in the literature as partial retirement. ${ }^{32}$ The naming of this instrument seems to refer to its primary function, that of alleviating the transition from an active working life to retirement. It was established in the Act of July $23^{\text {rd }}$, 1996, within the system of gradual retirement (AltTzG). ${ }^{33}$ The reduction of working time takes

p. 1; OECD, Thematic Follow-Up, Review of Policies to Improve Labour Market Prospects for Older Workers, Germany (Situation mid-2012), Paris 2012, p. 4.

27 K. Lipták, Hungary: The Role of Governments and Social Partners in Keeping Older Workers in the Labour Market, Dublin 2013, https://www.eurofound.europa.eu/observatories/eurwork/comparative-information/national-contributions/hungary/ hungary-the-role-of-governments-and-social-partners-in-keeping-older-workers-in-the-labour-market, (accessed: 7.06.2017).

28 Z. Kiss, K. Balogh, Increasing Reliance on Older Workers in the Labour Market, Dublin 2007, https://www.eurofound.europa.eu/ga/observatories/eurwork/articles/other/ increasing-reliance-on-older-workers-in-the-labour-market, (accessed: 7.06.2017).

29 Art. 120 of the Hungarian Labour Code.

30 Arbeitsgerichtsgesetz in der Fassung der Bekanntmachung vom 2. Juli 1979 (BGBI. I S. 853, 1036), das zuletzt durch Artikel 19 Absatz 6 des Gesetzes vom 23. Dezember 2016 (BGBI. I S. 3234) geändert worden ist.

31 B. Kraemer, Germany: Working Life Country Profile, Dublin 2015, http://www.eurofound. europa.eu/observatories/eurwork/comparative-information/national-contributions/ germany/germany-working-life-country-profile, (accessed: 18.06.2016).

32 B. Ebbinghaus, W. Eichhorst, Employment Regulation and Labour Market Policy in Germany, 1991-2005, "IZA Discussion Paper" 2006, December, no. 2502, p. 35.

33 Altersteilzeitgesetz vom 23. Juli 1996 (BGBI. I S. 1078), das zuletzt durch Artikel 4 des Gesetzes vom 28. März 2009 (BGBI. I S. 634) geändert worden ist. 
place in one in two ways - either by reducing the time spent at work by half until the employee is entitled to a retirement pension (the part-time model) or as a continuation of full-time employment for half the remaining period of retirement and cessation of work for remaining half (the block model). ${ }^{34}$ During the reduction of working time, the employee retains the right to the greater part of their remuneration. By the end of 2009, it was co-financed from public funds, provided that the employer recruited an unemployed person to fill the post. ${ }^{35}$ The law also encouraged social partners to develop the discussed instruments through collective agreements. Such agreements were concluded in the metalworking and electrical industries, ${ }^{36}$ for officials of public administration. ${ }^{37}$ Subsidisation of benefits to employees from public funds has now ended, which requires employers to fund the guarantees provided for in collective agreements themselves.

In Denmark, a program aimed at extending the period of professional activity of older workers was launched in 2013 to improve their employment conditions. It includes actions consisting of, among others, promoting healthy and safe working conditions, improving and updating professional qualifications, taking into account the needs of existing employees. Subsidies are available for employers. ${ }^{38}$ Moreover, the Preventive Fund plays an important role in respect of the psycho-social well-being of older workers. Its main purpose is to finance projects that prevent health degradation which are the result of working under conditions of exposure to onerous and harmful factors, ${ }^{39}$ as well as support for vocational rehabilitation and professional retraining. ${ }^{40}$ Adaptation of working conditions to the needs of older workers is also achieved through collective agreements. ${ }^{41}$ Collective agreements

34 S. Vogel, Young Workers to Substitute for Older Employees, European Observatory of Working Life, http://www.eurofound.europa.eu/observatories/eurwork/articles/young-workers-to-substitute-for-older-employees, (accessed: 12.05.2016).

35 M. Paluszkiewicz, Wybrane środki prawne wspomagajace utrzymanie zatrudnienia przez pracowników starszych w Niemczech, pp. 122-123 and the literature cited therein.

36 S. Vogel, Agreement on Partial Retirement in Metal and Electrical Industry, http://www. eurofound.europa.eu/printpdf/observatories/eurwork/articles/agreement-on-partial-retirement-in-metal-and-electrical-industry, (accessed: 12.05.2016).

37 O. Stettes, Germany: The Role of Governments and Social Partners in Keeping Older Workers in the Labour Market, Dublin 2013, http://www.eurofound.europa.eu/observatories/eurwork/comparative-information/national-contributions/germany/germany-the-role-of-governments-and-social-partners-in-keeping-older-workers-in-the-labour-market, (accessed: 12.05.2016).

38 OECD, Assessment and Key Recommendations - Working Better with Age in Denmark, Paris 2015, p. 10.

39 OECD, Thematic Follow-up Review of Policies to Improve Labour Market Prospects of older workers, Denmark (Situation mid-2012), Paris 2012, p. 4.

40 P. H. Jensen, Employment and Labour Market Policies for an Ageing Workforce and Initiatives at the Workplace, National Overwiev Report: Denmark, Dublin 2007, p. 4.

41 C. Jørgensen, Denmark: The Role of Governments and Social Partners in Keeping Older Workers in the Labour Market, Dublin 2013, http://www.eurofound.europa.eu/ observatories/eurwork/comparative-information/national-contributions/denmark/ 
play an important role in raising the awareness of employers on the value of employing older workers. ${ }^{42}$ Under collective agreements, especially in the private sector, practices are established for the organization of work for older workers, in particular flexible working hours, reduced working hours, the ability to change the type of work performed or tele-working. ${ }^{43} \mathrm{~A}$ frequently applied solution is the reduction of working hours, while still guaranteeing the current level of earnings. This is done by lowering the level of the employer's contribution to the second pillar of the pension and the payment of the difference as a supplementary remuneration. ${ }^{44}$ Due to the low percentage of employees over 55 returning to work within 12 months of the end of sickness benefits, a mechanism to promote the return to work of a recuperated employee is of interest. The employer is obliged to develop with such an employee measures to support the return to work. However, failure to do so does not incur any sanctions for any of the parties in the employment relationship. In addition, in certain cases, employees may also apply to the employer for a plan for retaining employment. A refusal to do so may cause the employer to face certain consequences if the employment relationship is terminated once the employee's incapacity for work has ceased. ${ }^{45}$

The actions of employers undertaken in Belgium in order to maintain or restore employment may be financed through the Vocational Experience Fund. ${ }^{6}$ It supports the implementation of a variety of projects aimed at prolonging professional activity, in particular by improving the quality of employment for workers who have reached 45 years of age. ${ }^{47}$ The fund's activities were intended to make it possible to reach a compromise between the increase in employment of older workers and the associated higher cost. ${ }^{48}$ The fund, financed from the budget, implements objectives with a range of time-based goals. In addition to the already identified main long-term task, which aims to prolong the professional activity of older workers, the fund undertakes actions to raise awareness among employers and other labour market entities on the issues related to the employment of older people. This not only concerns breaking down the stereotypes on employing older workers, ${ }^{49}$ but also

denmark-the-role-of-governments-and-social-partners-in-keeping-older-workers-in-the-labour-market, (accessed: 21.07.2016).

42 C. Jørgensen, Denmark: The Role of...

43 OECD, Ageing and Employment Policies..., p. 98.

44 Ibidem.

45 More details: M. Paluszkiewicz, Wybrane środki prawne wspierajace zatrudnienie pracowników starszych w Danii..., pp. 178-179 and the literature provided there.

46 Fonds de l'expérience professionnelle, http://www.emploi.belgique.be/fonds_de_ lexp\%C3\%A9rience_professionnelle.aspx\#, (accessed: 12.04.2016).

47 N. Contreras, E. Martelucci, A.-E. Thum, Active Ageing in Belgium, Mobilising the Potential of Active Ageing in Europe (MoPAct), Country Report, 2014, p. 43.

48 V. Hermans, R. Motmans, A. Himpens, The Professional Experience Fund - a Belgian Example for Support of the Quality of Work for Elderly Workers, Proceedings of the European Conference on Ergonomics, Bilbao 2010, p. 280.

49 N. Contreras, E. Martelucci, A.-E. Thum, Active ageing..., p. 43. 
provides information on legal instruments addressed to older workers. In particular, raising awareness of the additional entitlement in return for the transfer of an employee who has reached 50 years of age to a role with a lower physical burden. ${ }^{50}$ Short-term ventures include subsidizing projects submitted by employers. These may address improvements in working conditions, in particular regarding safety, as well as the protection of the health of workers and the adaptation of workstations, taking into account the principles of ergonomics. ${ }^{51}$

One measure aimed at lessening the workload is also the reduction of working hours. It is worth mentioning that apart from the statutory regulation in this regard, 52 there are also numerous collective agreements that adjust the situation to the needs of both employers and workers. ${ }^{53}$ Initially, the instrument was designed to reduce the unemployment rate - by obliging an employer to hire a new employee as part of another employee's redundancy. ${ }^{54}$ Later, as a result of the ideas promoted under the European Employment Strategy, this objective was modified. At present, it is aimed at reduction of the workload and granting financial security. 55

\subsection{Improving the professional qualifications of older workers}

Since the possession of current professional qualifications is one of the most important factors affecting employment, older people and those with low professional qualifications have been provided with a program for their continuous improvement and updating (WeGebAU, Weiterbildung geringqualifizierter und beschäftigter älterer Arbeitnehmer im Unternehmen). The program includes, in particular, workers aged 45 and over who are employed by small and medium-sized enterprises. Training, the scope of which goes beyond the requirements of the single workplace, is carried out by accredited external institutions, and their cost is partly (up to 75\%) reimbursed from

50 OECD, Thematic Follow-Up Review..., p. 6.

51 V. Hermans, R. Motmans, A. Himpens, The Professional..., p. 281.

52 Art. 99-107bis Loi de redressement contenant des dispositions sociales, 22 Janvier 1985, Moniteur belge 24-01-1985 no.1985021271, p. 699 et modifié plusieurs fois, http://www.ejustice.just.fgov.be/loi/loi.htm, (accessed: 12.05.2016).

53 http://www.cnt-nar.be/CCT-COORD/cct-077-bis.pdf, http://www.cnt-nar.be/CCT-COORD/cct-046.pdf, (accessed: 15.04.2016).

54 S. Devisscher, The Career Break (Time Credit) Scheme in Belgium and the Incentive Premiums by the Flemish Government, Peer Review 19-20 February 2004, Mutual Learning Programme (MLP) under the European Employment Strategy, sp 2, http://pdf.mutual-learning-employment.net/pdf/belgium\%2004/Discussion\%20paperBEL04.pdf, (accessed: 28.04.2016).

55 B. Van Looy, M. Kovalenko, D. Mortelmans, H. De Preter, Working Hour-reduction in the Move to Full Retirement: How Does this Affect Retirement Preferences of 50+ Individuals in Flanders?, Leuven-Antwerpen 2014, p. 13 and the literature cited; S. Devisscher, The Career..., p. 2. 
public funds. The need for the financial participation of employers, and also the employees themselves, in training costs is expected to have a positive impact on their effectiveness, while the scope of the training is to provide knowledge and skills that will strengthen the employees' position in the labour market. ${ }^{56}$ Public employment services also engage in actions aimed at lifelong learning. They have initiated pilot projects that provide personalized counseling. These were projects targeted at small and medium enterprises where there is usually no separate HR department responsible for the recruitment process and the career development of existing employees. ${ }^{57}$

In Denmark, there is a comprehensive system for the lifelong learning of adult workers and the training of the unemployed. 58 The primary objective of the system is to ensure a high level of education and professional mobility. ${ }^{59}$ The legal framework of this system is primarily created by national legislation, although collective agreements give workers the right to lifelong training. 60 Social partners are strongly committed to the implementation of specific solutions and can decide on the types of training, its duration, and the possible entitlements of employees involved in the qualification process, such as time off for training. The literature indicates that sectoral collective agreements governing the lifelong learning process in Denmark cover about $85 \%$ of all employees. ${ }^{61}$ There are circa 3000 training programs; each year the training offer is updated through, roughly, an additional 200 programs, replacing those withdrawn due to the lack of labour market relevance. These programs enable the acquisition of skills in professions operating in more than 100 areas of employment. The duration of training is highly varied, depending on the subject and the form (in-house and externally). The type of training, its form and duration are tailored to the individual needs of the participants. Acquisition of professional qualifications is certified by a relevant document. ${ }^{62}$ The system is financed mainly through public funds. ${ }^{63}$

56 More details: M. Paluszkiewicz, Wybrane środki prawne wspomagajace utrzymanie zatrudnienia przez pracowników starszych w Niemczech..., pp. 121-122 and the literature cited therein. J. S. Heywood, U. Jirjahn, The German..., s. 4; Social Security at a Glance 2015, Bonn 2015, p. 23; O. Stettes, Germany: The Role of Governments; Ch. Singer, O.-S. Toomet, On Governemnt-subsidized Training Programs for Older Workers, "IAB Discussion Paper" 2013, no. 21, p. 7.

57 Bundesagentur..., p. 10.

58 Voksen-og Efteruddannelserne, VEU - C. Jørgensen, Denmark: Collective bargaining and continuous vocational training, Dublin 2009, http://www.eurofound.europa.eu/ observatories/eurwork/comparative-information/national-contributions/denmark/ denmark-collective-bargaining-and-continuous-vocational-training, (accessed: 29.09.2016).

59 C. Jørgensen, Denmark: The role of...

60 More details: M. Paluszkiewicz, Wybrane środki prawne wspierajace zatrudnienie pracowników starszych w Danii..., p. 173 and literature provided there.

61 C. Jørgensen, Denmark: Collective bargaining...

62 More details: M. Paluszkiewicz, Wybrane środki prawne wspierajace zatrudnienie pracowników starszych w Danii, p. 174 and the literature provided there.

63 European Centre for the Development of Vocational Training (CEDEFOP), Vocational Education and Training in Denmark. Short Description, Luxembourg 2012, p. 56. 


\subsection{Protection of employment sustainability}

In Hungary, an employer cannot terminate an indefinite employment contract five years before the employee reaches statutory retirement age. ${ }^{64}$ However, the prohibition on dismissal does not apply in cases where the employer is entitled to terminate the employment contract without notice, i.e. when the employee intentionally or through gross negligence commits a serious breach of the basic obligation of the employment relationship or acts in a way that prevents the continuation of the employment relationship. ${ }^{65}$ In addition, the employer may terminate the employment relationship with the employee due to the loss of his/her ability to work and the employer is not able to entrust him/her with other work appropriate in terms of education, skills and previous professional experience, or when the employee refuses to accept this role. ${ }^{66}$ According to Art. 66 (8) of the Hungarian Labour Code, termination of a fixed-term employment contract is only permissible under exceptional circumstances, such as the bankruptcy or liquidation of the employer, loss of the employee's ability to work or failure to continue employment due to force majeure.

The period of the employer's termination of an employment contract is dependent on the employee's length of service, and thus, indirectly, on their age. ${ }^{67}$ In the case of wrongful termination (e.g. lack of justification) of the employment contract by the employer, the employee is entitled to severance pay. ${ }^{68}$ On the other hand, when an employer terminates a contract of employment with an employee who is less than 5 years from retirement entitlement, the severance pay shall be increased by the equivalent of 3 months' salary. ${ }^{69}$ Older workers who have the right to a pension at the time of dismissal are not entitled to severance pay. ${ }^{70}$

The rules for termination an employment relationship in Germany are primarily regulated by the Civil Code (BGB) and the Law on Protection against Unfair Dismissal of Employment (KSchG). Employees are protected in the case of dismissal provided they have a specific in-company experience and they are employed by larger employers. Older workers are not covered by the special protection of the employment relationship sustainability, ${ }^{71}$ however, there are no obstacles

64 Article 66 (4) of the Hungarian Labour Code.

65 Article 66 (4) in conjunction with art. 78 (1) of the Hungarian Labour Code.

66 Article 66 (5) of the Hungarian Labour Code.

67 Article 69 (1) and (2) of the Hungarian Labour Code; cf. OECD, Detailed Description of Employment Protection Legislation 2012-2013, Hungary, OECD EPL Database, update 2013, p. 40.

68 OECD, Detailed Description..., p. 40.

69 Article 77 (4)(c) of the Hungarian Labour Code.

70 Article 77 (5)(a) of the Hungarian Labour Code.

71 More details: M. Paluszkiewicz, Wybrane środki prawne wspomagajace utrzymanie zatrudnienia przez pracowników starszych w Niemczech, pp. 124-125. 
to such protection being introduced through sectoral collective agreements ${ }^{72}$ or within individual employment contracts. ${ }^{73}$ On the other hand, standard protection of the employment relationship sustainability is applied to older workers. When specifying an employee for dismissal, the employer must take into account in particular age, seniority, alimony obligations or disability. The work council should be consulted in this regard. ${ }^{74}$ Termination notices for indefinite employment contracts are dependant on seniority and may be extended or reduced by collective agreements and individual employment contracts. ${ }^{75}$

In Denmark, rules governing the termination of employment are regulated by the Employment Relations Act ${ }^{76}$, collective agreements and individual employment contracts ${ }^{77}$. These are designed in such a way that they generally provide employers with a relatively high degree of freedom in the termination of contracts. Older workers are protected by the same principle as the other employees and are not subject to special protection by law, though this may be established through a collective agreement. The length of notice period is affected by the position and type of work (physical/intellectual). With regard to manual workers, many collective agreements provide for periods of notice tailored to the needs of a particular industry; these are usually short. ${ }^{78}$ In the literature on the example of the Danish experience, the formulated view is that the high level of protection of employment sustainability has a greater impact on the fixing of unemployment rate than the generous social security system. ${ }^{79}$ The research clearly indicates that low protection of employment sustainability, which is one of the determinants of labour market flexibility and the whole flexicurity model, clearly promotes the tendency of older people to exercise the right to early retirement ${ }^{80}$ or other benefits of a similar function, such

72 O. Stettes, Germany: The Role of Governments...

73 EUROFOUND, Protection Against Dismissal: Germany, http://www.eurofound.europa. eu/efemiredictionary/protection-against-dismissal-1, (accessed: 13.07.2016).

74 B. Kraemer, Germany: Working Life Country Profile...; B. Waas, Labour Policy and Fixed-Term Employment Contracts in Germany [in:] Labour Policy on Fixed-term Employment Contracts, Tokyo 2010, p. 26; B. Ebbinghaus, W. Eichhorst, Employment Regulation..., p. 11.

75 Ibidem.

76 Bekendtgørelse af lov om retsforholdet mellem arbejdsgivere og funktionærer, LBK nr 81 af 03/02/2009, https://www.lovtidende.dk/Forms/L0700.aspx?s31=10\&s21=Fu nktion\%c3\%a6rloven+, (accessed: 28.07.2016). Consolidation Act on the Legal Relationship between Employers and Salaried Employees, http://www.ilo.org/dyn/natlex/ docs/ELECTRONIC/87041/100044/F6755161/DNK87041\%20in\%20English.pdf, (accessed: 28.07.2016).

77 OECD, Detailed Description of Employment Protection Legislation 2012-2013, Denmark, Employment Protecton Database 2013, p. 20.

78 More details: M. Paluszkiewicz, Wybrane środki prawne wspierajace zatrudnienie pracowników starszych w Danii, pp. 182-183 and the literature provided there.

79 T. M. Andersen, A Flexicurity Labour Market in the Great Recession: The Case of Denmark, "De Economist" 2012, no. 160, p. 139.

P. H. Jensen, Reversing..., p. 660. 
as unemployment benefits or disability benefits. ${ }^{81}$ This puts the weakest entities on the labour market at a disadvantage. ${ }^{82}$

In contrast, in Belgium, the rules governing the length of notice period required for the termination of employment contracts, established separately for manual and intellectual workers, were questioned as breaching the principles of equality and non-discrimination by the Belgian constitutional court in its judgment of July $7^{\text {th }}, 2011 .{ }^{83}$ Beginning in 2014, new rules, uniform for all employees, determining the notice periods were defined, regardless of the type of work performed or salary. In general, the length of the notice period depends on seniority. ${ }^{8485}$ If the employer terminates the indefinite period employment contract without notice, they will be obliged to pay the employee the severance pay for the period of notice, including not only the current salary, but any benefits arising from the employment relationship. ${ }^{86}$ Solutions serving to protect the employment of older workers have been introduced into the legal framework in the field of collective redundancies. ${ }^{87}$ Until 2012, in the case of collective redundancies, employers in Belgium generally had the freedom to choose which employees were dismissed. After the changes, employers with at least $20 \mathrm{em}$ ployees are required to ensure that employees classified for dismissal reflect the employment structure of the employer according to age (the age pyramid). 88 When the employment relationship is terminated on an employer's initiative,

81 T. Filges, M. Larsen, P. J. Pedersen, Retirement: Does Individual Unemployment Matter? Evidence from Danish Panel Data 1980-2009, “IZA Discussion Paper” 2012, May, no. 6538, p. 2.

82 A. Lauzadyte, Unemployment. Employment and Inactivity in Denmark: An Analysis of event History Data, "Economics Working Papers", 2007, no. 18, p. 2.

83 Arrêt n¹25/2011 du 7 juillet 2011, http://www.const-court.be/public/f/2011/2011-125f. pdf, (accessed: 29.04.2016).

84 Art. 37/2 § 2 Loi relative aux contrats de travail, Moniteur belge 1978.08.22, No. 70303, p. 9277 et modifié plusieurs fois, http://www.ejustice.just.fgov.be/loi/loi.htm, See also M. Paluszkiewicz, Wybrane środki prawne wspomagajace utrzymanie zatrudnienia pracowników starszych w Belgii, p. 11 and references cited therein.

85 Art. $37 / 2$ \& 1 Loi relative aux contrats de travail.

86 Art. $39 \S 1$ Loi relative aux contrats de travail. Van Bael \& Bellis (eds) Business Law Guide to Belgium, Kluwer Law International 2003, p. 337.

87 The main regulations in this area are: Loi portant des dispositions en faveur de l'emploi, 13 Fevrier 1998, Moniteur belge 19-02-1998, No. 12088, p. 4643 et modifié plusieurs fois (art. 62-70), and concluded on the basis of art. $66 \S 1$ of this Act collective agreement no. 24 Convention collective de travail n ${ }^{\circ} 24$ du 2 octobre 1975 concernant la procédure d'information et de consultation des représentants des travailleurs en matière de licenciements collectifs, http://www.cnt-nar.be/CCT-COORD/cct-024.pdf, (accessed: 22.04.2016, Convention collective de travail $n^{\circ} 10$ du 8 mai 1973 relative aux licenciements collectifs, http://www.cnt-nar.be/CCT-COORD/cct-010.pdf, (accessed: 22.04.2016). And Arrêté royal sur les licenciements collectifs, 24 Mai 1976, Moniteur belge 17-09-1976, No. 52409, p. 11663 et modifié plusieurs fois.

88 Art. 63 Loi portant des dispositions diverses (I), 29 MARS 2012, Moniteur belge 30-032012, No. 21057, p. 20537 et modifié plusieurs fois. 
older workers have also the right to outplacement, ${ }^{89}$ established under collective agreement No. 104 - the plan for the employment of older people..$^{90}$ Outplacement means all services and benefits, such as career guidance and job search plans that are carried out individually or in groups by a third party at the expense of the employer. The purpose of this project is to assist employees who have lost their jobs in gaining a new one or in setting up a new business as soon as possible. The outplacement procedure is mandatory for employers. Failure to do so results in criminal and administrative liability. ${ }^{91}$

89 P.-F. Lovens, Agreement on Outplacement for Older Workers, Dublin 2002, http://www. eurofound.europa.eu/observatories/eurwork/articles/agreement-on-outplacement-for-older-workers, (accessed: 8.04.2016).

90 http://www.cnt-nar.be/CCT-COORD/cct-104.pdf, (retrieved on April 8, 2016); M. Keune, Sector-level Bargaining and Possibilities for Deviations at Company Level: Belgium, Dublin 2011, http://www.eurofound.europa.eu/publications/report/2011/belgium/industrial-relations/sector-level-bargaining-and-possibilities-for-deviations-at-company-level-belgium, (accessed: 8.04.2016).

91 Cf. M. Paluszkiewicz, Wybrane środki prawne wspomagające powrót bezrobotnych osób starszych na rynek pracy w Belgii, pp. 110-111 and the literature cited therein. 


\section{Legal measures to support reintegration of unemployed older people into the labour market in Belgium, Denmark, Germany and Hungary}

\subsection{Prohibition of discrimination in access to employment on the grounds of older age}

In Hungary, according to the aforementioned law on equal treatment, the prohibition of discrimination on the grounds of age applies to the formulation of job offers, as well as to the recruitment phase for employment. ${ }^{1}$ However, differential treatment in access to employment will be considered justified if age is significant due to the nature of the work, and the actions taken will be proportionate and appropriate to achieving the intended purpose. ${ }^{2}$ There is no regulation on the permitted (prohibited) content of an application for employment, therefore the candidate for employment is not required to disclose their age. ${ }^{3}$ In the case of refusal of employment in violation of the prohibition of discrimination on the grounds of age, the candidate may not the claim for employment. ${ }^{4}$ However, such a person may claim damages or redress in the court. ${ }^{5}$

In Germany, the prohibition on age discrimination refers to apprentices, job applicants and persons who setting-up businesses. This prohibition in particular concerns the formulation of job offers, which should be based on neutral criteria. An employee's age requirement must be objectively justified, for example, the intention to enter into a fixed-term employment contract with a senior employee on a specific basis. Violation of the prohibition of discrimination on the grounds of age in the pre-employment stage entitles the holder to make a claim before the court. ${ }^{6}$

In Denmark, age is one of the criteria for forbidden differentiation in the preemployment phase. Examples that violate the prohibition of discrimination may be specifying a particular age range for an employee or refusing to employ a candidate on account of his or her age. In the literature, however, it is highlighted that the latter situation is very difficult to prove in practice without knowing the qualifications and experience of the other candidates. ${ }^{7}$ Job offers should also be formulated in a neutral way. If they specify only experienced employees, this may be considered discrimination

\footnotetext{
1 C. K. Lehoczky, Legal Instruments..., p. 71; I. Krisch, N. Kürti, Hungary..., p. 161.

2 I. Krisch, N. Kürti, Hungary..., p. 161.

3 I. Krisch, N. Kürti, Hungary..., p. 162.

4 Ibidem.

5 Ibidem.

6 More details: M. Paluszkiewicz, Wybrane środki prawne wspierajqce bezrobotne osoby starsze w podjęciu zatrudnienia w Niemczech, "Polityka Społeczna" 2017, no. 2, p. 33 and the literature cited therein.

7 S.H. Madsen, Denmark..., p. 78.
} 
against younger workers. It is not forbidden for an employer to request te age of a candidate in the recruitment process. This means that information of this type can be obtained from candidates for employment. ${ }^{8}$ Under certain conditions, it is permissible to use the age criterion in the pre-employment phase. For example, this may be the establishment of specific conditions for access to employment for older workers, including the formulating of these conditions which meet older worker needs. ${ }^{9}$

In Belgium, the prohibition of discrimination applies not only to the shaping of employment conditions and the measures taken to address this, but also to the establishment of employment relations. In addition to the regulations already outlined, collective agreement No. 38 of December $6^{\text {th }}, 1983$ on the recruitment and selection of workers is of crucial significance. ${ }^{10}$ It prohibits age differentiation ${ }^{11}$ in the process of recruitment and selection. However, this may be justified if age is relevant for the particular type of work or the nature of the employer's activity. ${ }^{12}$ Prohibition of discrimination on the grounds of age refers in particular to the way in which job offers are formulated. An allegation of discrimination or incitement to discrimination may be made to the employment agency as well as the user of its services when (acting on the basis of the guidance given by the latter) a job offer is formulated or acts against employees on the basis of age. ${ }^{13}$ If there is a breach of the prohibition of discrimination at the pre-employment stage, the applicant does not have a right to employment in the employing entity; although they may demand compensation. ${ }^{14}$

\subsection{Subsidizing the employment of unemployed older persons}

In Hungary, the employment costs of taking on an out-of-work person who is recognised as disadvantaged on the labour market, among others because of age, is subsidised for a maximum duration of 12 months. ${ }^{15}$ Initially, an employer

$8 \quad$ S.H. Madsen Denmark..., p. 80.

$9 \quad$ R. V. Andersen, M. V. Petersen, E. Fries-Tersch, Safer and Healthier Work at any Age. Country Inventory: Denmark, European Agency for Safety and Health at Work, Bilbao 2016, p. 23.

10 Convention collective de travail $n^{\circ} 38$ du 6 décembre 1983 concernant le recrutement et la sélection de travailleurs, http://www.cnt-nar.be/CCT-COORD/cct-038.pdf, (accessed: 11.04.2016).

11 This criterion is indicated indirectly, by reference to the collective agreement no. 95 of October $10^{\text {th }}, 2008$ on equal treatment in all phases of employment, http://www.cnt-nar. be/CCT-COORD/cct-095.pdf (accessed: 11.04.2016). Article 2 of this agreement indicates inter allia age as a prohibited criterion for differentiating the employment situation.

12 Y. Stox, Belgium..., p. 28.

13 Cf. M. Paluszkiewicz, Wybrane środki prawne wspomagajace powrót bezrobotnych osób starszych na rynek pracy w Belgii, pp. 109-110.

14 Y. Stox, Belgium..., p. 29.

15 Z. Cseres-Gergely, Hungary, EEO Review, Employment Policies to Promote Active Ageing, European Employment Observatory, European Commission 2012, p. 7. 
may receive a refund covering up to $100 \%$ of the worker's salary and social security contributions, but not more than twice the minimum wage. Then the refund is up to $50 \%$ of the salary, but not more than the set limit. ${ }^{16}$ After fulfilling a number of additional conditions, the employer is required to employ the older employee without financial support for a period at least equal to the payment of the subsidies.

On the basis of the Act of October $1^{\text {st }}, 2012$ on job protection, ${ }^{17}$ a system of incentives was introduced to promote, inter alia, employment of people over 55 and the long-term unemployed. These include reducing the cost of social security contributions and professional training fees for both those already employed and persons to be employed. Depending on the type of person employed, the reduction may be total or partial. 18

The Hungarian labour market policy is increasingly based on public work programmes, making them the main instrument for activating the unemployed. ${ }^{19}$ A significant section of the long-term unemployed are older persons. ${ }^{20}$ Hence, their participation in these programs is significant. ${ }^{21}$ The right to reject public work employment offers is not available even if they hold a higher professional qualification than required to perform the job offered. ${ }^{22}$ If public employment services can not offer a job on the so-called open labour market, participation in the public work program for a period of at least 30 days is compulsory. ${ }^{23} \mathrm{Re}$ fusal to participate may involve the reduction of unemployment benefits and even the loss of unemployed or job-seeker status. ${ }^{24}$ Due to the increasing scale of public works, it is pointed out that the probability of receiving a job offer on the so-called

16 K. Lipták, Hungary...

17 2012. évi CXLVI. törvény a munkahelyvédelmi akciótervben foglaltak megvalósítása érdekében szükséges egyes törvények módosításáról, Magyar Közlöny, 2012-10-15, vol. 136, pp. 23365-23373; Z. Cseres-Gergely, K. Varadovics, Labour Market policy Interventions September 2012-January 2014, [in:] K. Fazekas, L. Neumann (eds.), The Hungarian Labour Market 2014, Budapest 2014, p. 223.

18 OECD, Economic Surveys: Hungary, May 2016, Paris 2016, p. 103.

19 K. Bördös, Public Work Programmes in Hungary, [in:] K. Fazekas, J. Varga (eds.), The Hungarian Labour Market 2015, Budapest 2015, p. 76.

20 J. Kollo, A. Scharle, The Impact of the Expansion of Public Work Programs on Long-term Unemployment, [in:] K. Fazekas, G. Kézdi (eds.), The Hungarian Labour Market 2012. In Focus: the Evaluation of Active Labour Market Programs, Budapest 2012, p. 124.

21 Average Monthly Number of Participants in the Public Work Scheme, http://kozfoglalkoztatas.kormany.hu/information-on-the-current-status-of-public-work-scheme-pws-in-hungary, (accessed: 14.06.2017).

22 K. Bördös, Public work..., p. 71; D. Szikra, Democracy and Welfare in Hard Times: The Social Policy of the Orbán Government in Hungary Between 2010 and 2014, "Journal of European Social Policy" 2014, vol. 24 (5), p. 7.

23 D. Szikra, Democracy..., p. 7; F. Albert, Public Works in Hungary: an Efficient Active Labour Market Tool?, European Social Policy Network - Flash report 2015/35, European Commission, Brussels 2015, p. 3.

K. Bördös, Public Work..., p. 71. 
open labour market equals 1:5. ${ }^{25}$ The basis for provision of work is a special contract for the performance of public work, ${ }^{26}$ in contrast to employment contracts concluded under the previous regulation. ${ }^{27}$ In practice, this means that people participating in public work may receive remuneration lower than the minimum wage. ${ }^{28}$ In $2008,4 \%$ of people employed in public work earned less than the subsistence level, while in 2010 this figure had increased to about $19 \%$. Thanks to the application of certain short-term solutions, incidents of salaries that did not guarantee the minimum subsistence level have been reduced to around $13 \% .29$ The annual leave for persons performing this work is not age-dependent, as it is in the case of normal employment, and is 20 working days. Other rights and obligations of people employed to perform public works arise from the Hungarian Labour Code. ${ }^{30}$ The duration of public work is generally 12 months but can be extended additionaly to no more than 6 consecutive months. ${ }^{31}$ Working hours depend on the type of program in which the unemployed participate and range from 4 to 8 hours per day. ${ }^{32}$

As a result of the changes introduced in 2015, employers from the private sector can also offer vacant positions, mainly seasonal, which may be applied for by persons performing public works. ${ }^{33}$ Starting on February $1^{\text {st }}, 2016$, an employment bonus was introduced to encourage persons performing public work to find employment in the open labour market. It is the sum of the remuneration for the time the person would have performed public work if he/she had not found employment on their own. ${ }^{34}$ This instrument is addressed primarily to people in a particularly

25 F. Albert, Public Works..., p. 4 and the literature cited therein.

26 Hungarian public works portal (Közfoglalkoztatasi Portal), Information on the current status of Public Work Scheme (PWS) in Hungary, http://kozfoglalkoztatas.kormany.hu/ download/8/3a/51000/Information\%20on\%20the\%20current\%20status\%20of\%20 Public\%20Work\%20Scheme\%20(PWS)\%20in\%20Hungary.pdf, (accessed: 14.06.2017), p. 1-2; K. Bördös, Public work..., p. 70.

27 K. Bördös, Public work..., p. 70.

28 Ibidem, pp. 71-72; D. Szikra, Democracy..., p. 8; A. Kiss, P. Belyó, A. Kunert, M. Komiljovics, K. György, Hungary: Working Life Country Profile, Dublin 2015, https://www.eurofound.europa.eu/observatories/eurwork/comparative-information/national-contributions/hungary/hungary-working-life-country-profile, (accessed: 9.06.2017).

29 A. Kiss, Hungary: Bleak Prospects for Public Sector Workers under Economic Programme, Dublin 2015, https://www.eurofound.europa.eu/observatories/eurwork/articles/ working-conditions/hungary-bleak-prospects-for-public-sector-workers-under-economic-programme (accessed: 19.06.2017).

30 K. Bördös, Public Work..., p. 71.

31 Hungarian public works portal..., p. 70.

32 K. Bördös, Public Work..., pp. 71-72.

33 Hungarian public works portal..., p. 4; A. Scharle, Labour Market Policy Tools (May 2015March 2016), [in:] Z. Blazsko, K. Fazekas (eds.), The Hungarian Labour Market 2016, Budapest 2016, p. 172.

34 A. Scharle, Labour Market..., p. 173; OECD Economic Surveys: Hungary..., p. 107. 
difficult situation on the labour market, as well as to those wishing to take up employment on the primary labour market. ${ }^{35}$

German legislation also provides instruments to encourage employers to take on older workers. One of them is a partial refund of employment costs. ${ }^{36}$ It is available to employers engaging a worker of at least 50 years of age who is considered to be in a particularly vulnerable position on the labour market. As of 2015, subsidies can be paid up to a maximum of 36 months. ${ }^{37}$ Another instrument that can be applied to unemployed older people is the subsidized employment of long-term unemployed persons who have at least two significant obstacles to employment (Beschäftigungszuschuss). ${ }^{38}$ The employer has the opportunity to receive subsidies of up to $75 \%$ of the cost of employment, and, currently, their payout duration is not limited. ${ }^{39}$ Another incentive to employ older workers for those employers who fear reduced productivity on the grounds of advanced age is the so-called integration grant. The aim here is to compensate for the employment of the unemployed experiencing particular difficulties in taking up employment, usually with reduced productivity in terms of performing work. ${ }^{40}$ It cannot exceed $50 \%$ of the employee's gross wage and decreases over the time of the grant. The maximum support time for employees over 50 is 36 months, which is three months longer than for younger workers. This instrument also provides solutions to prevent abuse by employers. At the end of the pay period, the employer is required to continue the employment of the older worker for a specified time period. ${ }^{41}$

In Germany, public work may be used, to a certain extent, to activate older people. The so-called one-euro-jobs ${ }^{42}$ may constitute an example. The name of this form of employment is due to the fact that the unemployed person receives remuneration for every hour of work, also referred to in the literature as compensation for increased expenditures, ${ }^{43}$ which ranges from a euro to one and a half, in addition to the unemployment benefit type II. The low level of benefits is still a motivation

35 Hungarian public works portal..., pp. 4-5.

$36 \S 421 \mathrm{f}$ Das Dritte Buch Sozialgesetzbuch - Arbeitsförderung - (Artikel 1 des Gesetzes vom 24. März 1997, BGBI. I S.594, 595), das zuletzt durch Artikel 2 des Gesetzes vom 17. Juli 2017 (BGBI. I S. 2581) geändert worden ist.

37 O. Stettes, Germany: The Role of Governments...

$38 \S 16$ e Das Zweite Buch Sozialgesetzbuch - Grundsicherung für Arbeitsuchende - in der Fassung der Bekanntmachung vom 13. Mai 2011 (BGBI. I S. 850, 2094), das durch Artikel 20 des Gesetzes vom 17. Juli 2017 (BGBI. I S. 2541); J. Wolff, G. Stephan, Subsidized Work before and after the German Hartz Reforms: Design of Major Schemes, Evaluation Results and Lessons Learnt, "IZA Journal of Labor Policy” 2013, vol. 2:16, p. 8.

39 Wider: M. Paluszkiewicz, Wybrane środki prawne wspierajqce bezrobotne osoby starsze w podjęciu zatrudnienia w Niemczech, p. 35 and the literature cited therein.

40 J. Wolff, G. Stephan, Subsidized..., pp. 5-6.

41 Wider: M. Paluszkiewicz, Wybrane środki prawne wspierajqce bezrobotne osoby starsze w podjęciu zatrudnienia w Niemczech, s. 34 and the literature cited therein.

$42 \S 16 \mathrm{~d}$ SGB II.

43 K. Nyklewicz, Nowa strategia aktywizacji bezrobotnych w Niemczech, "Polityka Społeczna” 2010, no. 2, p. 26. 
to seek permanent (non-subsidized) employment. For this purpose to be achieved, one-euro-job employment should be of a non-full-time nature, and the working time should not exceed 30 hours a week. ${ }^{44}$ Refusal to participate in the program is linked to cessation of entitlement to benefits. 45 The one-euro-job is implemented in the public or non-profit sector, so as not to replace employment in the economy. Studies have shown that it was most often implemented in the public sector, especially among those entities providing educational, health and cultural services. ${ }^{46}$ Participation is temporary and limited to those cases where there is no opportunity of a suitable job, vocational training or other forms of assistance. Therefore, the recipients are unemployed persons in a particularly difficult situation on the labour market, the older people, among others.

In Denmark, an employer who takes on a long-term unemployed person who has reached the age of 55 can benefit from public funding for up to 6 months. What's more, it is an instrument that motivates an unemployed person to look for an employer who, in return for the received benefit, is obliged to hire the person for a specified period of time. This form of support is aimed at the private sector. ${ }^{47}$ The goal is to support the sustainable return of unemployed older persons to the labour market. ${ }^{48}$ Public works are also used to activate the unemployed older people. The so-called "senior job" is form of employment which can only be performed in the public sector, specifically in the local self-government region where the person resides. The basis of employment is a full-time employment contract, entered into until the person acquires the right to an early retirement, no longer than 5 years. This form of employment can benefit unemployed persons aged 55-59 who have already exhausted the right to unemployment benefit. The municipality which employs the person on a full-time basis, receives subsidies. ${ }^{49}$ It is emphasized that this is an expensive instrument, available only to a select group of registered unemployed, so should be gradually eliminated or significantly reduced. 50

Older employees who have at least a 50\% permanently reduced ability to work and have the right to incapacity benefits can take up employment in the form of the so-called flex job. This type of work can be performed regardless of age, 51

44 K. Hochmeyer, Effectiveness of One-Euro-Jobs. Do Programme Characteristics Matter?, "IAB Discussion Paper" 2009, no. 20, p. 10.

45 K. Hochmeyer, Effectiveness..., p. 8.

46 K. Hochmeyer, Effectiveness..., p. 10.

47 OECD, Thematic Follow-up Review of Policies to Improve Prospets of Labour Market Situation of Older Workers, Denmark..., p. 4.

48 P. K. Madsen, EEO Review: Employment Policies to Promote Active Ageing: Denmark, European Employment Observatory, European Commission 2012, p. 6.

49 OECD, Thematic Follow-up Review of Policies to Improve Labour Market Prospects for Older Workers, Denmark..., p. 3-4.

50 More details: M. Paluszkiewicz, Wybrane środki prawne wspomagające powrót osób starszych na rynek pracy w Danii, "Studia z Zakresu Prawa Pracy i Polityki Społecznej” 2017, vol. 24, no. 3, p. 188.

51 OECD, Ageing and Employment Policies..., p. 146. 
however, in practice, more than half of the recipients are over 50 years old. ${ }^{52} \mathrm{~A}$ significant proportion of the employees were receiving unemployment benefits before qualifying for work in this system. ${ }^{53}$ The employer pays remuneration corresponding to the quantity and quality of the work performed, while a public contribution supplements the remuneration. ${ }^{54}$ For those over the age of 40 , employment can be subsidized indefinitely. There is a low proportion of people undertaking full-time, non-subsidized employment after this form of support. ${ }^{55}$

Examples of financial support for employers engaging older workers are provided in the so-called Belgian Activa Plan. It allows, above all, a partial reduction of the cost of social security contributions and also a reduction of the costs of the remuneration itself. ${ }^{56}$ It covers all employers from the private sector and certain employers from the public sector. Its main purpose is to combat long-term unemployment, including those persons who have reached at least 45 years of age. The reduction in the cost of contributions depends on age and length of time he or she was unemployed. 57

\subsection{Vocational training of the older unemployed}

In the reforms of the Hungarian labour administration, the task of vocational training and adult education has been entrusted to a newly created entity - the National Office for Vocational Training and Adult Education, operating within the structure of the Ministry of National Economy and financed directly from the central budget. ${ }^{58}$ One of its most important tasks is the management of the National Employment Fund, among others, to subsidize employee training. 59

Training subsidies are granted through an individual minister's decision to support new jobs, as well as training workshops in the workplace. As far as training

52 OECD, Assessment and Key Recommendations..., p. 11.

53 V. Jensen, B. Lundager, A. Luther Christensen, K. Fonager, Unemployment Under the Flex Job Scheme Increases the Risk of Permanent Social Security Benefits, "Danish Medical Journal" 2014, April, p. 3.

54 V. Jensen, B. Lundager, A. Luther Christensen, K. Fonager, Unemployment..., p. 1; OECD, Ageing and Employment Policies..., p. 146.

55 OECD, Assessment and Key Recommendations..., p. 11.

56 M. Rigo, V. Vandenberghe, F. Waltenberg, Ageing and Employability. Evidence from Belgian Firm-Level data, "Institut de Recherches Économiques et Sociales (IRES) Discussion Paper" 2012, no. 11, pp. 2-3; N. Contreras, E. Martelucci, A.-E. Thum, Active Ageing..., p. 45; A. Albanese, B. Cockx, Permanent Wage..., p. 9.

57 Federal Public Service of Employment, Labour and Social Dialogue, http://www.emploi. belgique.be/defaultTab.aspx?id=704; http://www.onem.be/fr/documentation/feuille-info/e1, (accessed: 25.04.2016).

58 Z. Cseres-Gergely, K. Varadovics, Labour Market policy..., p. 193.

59 Ibidem. 
subsidies to create new jobs are concerned, one of the conditions for receiving support is the creation of at least 50 jobs and the retention in full-time employment of at least $70 \%$ of participants one and a half years after completion. ${ }^{60}$ The basic subsidy rate is up to $50 \%$ of training costs. It may, however, be increased; in particular when a person with a limited capacity to work or in a special situation on the labour market participates in the training and also when subsidies are requested by so-called small employers. ${ }^{61}$ The size of the total subsidy is determined by the size of the employer. ${ }^{62}$ As regards subsidizing the creation of training workshops in the workplace, the refund is also partial and the employer is required to organize a suitable number of apprenticeships. ${ }^{63}$

In Germany, the unemployed can avail of, in particular, vocational training vouchers within WeGebAU. They are targetted at those unemployed persons who are least distant from the labour market. An unemployed person during the validity period of the voucher is obliged to make his own selection of the training institution. The scope of the training, its maximum duration, the intended purpose of education, territorial coverage and the maximum training fee covered by public funds, is determined by the public employment services. ${ }^{64}$ In Denmark, training programs are a prerequisite for ensuring a flexible labour market, ${ }^{65}$ thus they are also addressed at the unemployed. ${ }^{66}$ For example, local employment services may request that a training institution conduct a course in those occupations for which there is a demand on the local labour market. ${ }^{67}$ Unemployed persons participating are exempt from fees; the cost of their participation being covered by public funds. ${ }^{68}$

\subsection{Flexible forms of employing unemployed older people}

Employment under fixed-term contracts is generally not widespread in Hungary. It has been pointed out, however, that this type of contract is often used as a basis for employing formerly out of work people, especially those older workers who have a low level of education. ${ }^{69}$ According to the Hungarian Labour Code, the maximum

60 Ibidem, p. 177.

61 Ibidem.

62 Ibidem.

63 Ibidem, pp. 177-178.

64 More details: M. Paluszkiewicz, Wybrane środki prawne wspierajace bezrobotne osoby starsze w podjęciu zatrudnienia w Niemczech, p. 36 and the literature cited therein.

65 European Centre for the Development of Vocational Training (CEDEFOP)..., p. 39.

66 Ibidem.

67 European Centre for the Development of Vocational Training (CEDEFOP)..., p. 43.

68 European Centre for the Development of Vocational Training (CEDEFOP)..., p. 55.

69 B. Nacsa, Fixed-term Contracts in Law on Paper and in Practice. Remarks to the Flexisurity Debate, Annales Universitatis Scientiarium Budapestinensis de Rolando Eötvös Nominatae Sectio luridica, tomus XLIX, annus 2008, p. 354. 
duration of a fixed-term employment contract is 5 years. This period includes any renewal of the contract made by the parties as well as all subsequent employment contracts between them, if there has been no more than 6 months between the previous termination and the subsequent termination. ${ }^{70}$

In Germany the conclusion of a fixed-term contract for an extended period of time requires an objective reason for such extension. However it is permissible to conclude a fixed-term employment contract with an employee who has reached the age of 52 without having to give an objective reason if he or she was previously unemployed for a period of at least 4 months or was involved in activation measures for the specified period. In this case, however, the maximum duration of the contract can not exceed 60 months. ${ }^{71}$ Two forms of casual employment (often parttime, combined with the exemption of social security contributions) - mini- and midijobs - were also implemented. Persons under these forms of employment may benefit from subsidies, including a partial reduction in the cost of social security contributions $^{72}$ on the side of the employee, ${ }^{73}$ as well as tax exemptions. ${ }^{74}$

In Denmark, the fixed-term employment contract is not a widespread form of employment of the older people. ${ }^{75}$ Term contracts are agreed for a specified period, or for a specific task. In general, there is no limit for successive fixed-term contracts by the same parties, but the next contract must be justified by the existence of an objective such as the completion of a particular task or the specific needs of the employer. ${ }^{76}$

\subsection{Services offered to unemployed older people by public employment services}

Hungarian public employment services provide assistance to all persons concerned, while the individualization of the services enables the needs of the older unemployed to be taken into account. ${ }^{77}$ However, these face significant application barriers. The literature points to the fact that as a result of the recent economic crisis

70 OECD, Detailed Description of Employment Protection Legislation 2012-2013, Hungary, OECD EPL Database, update 2013, p. 40.

71 OECD, Detailed Description of Emloyment Protection Legislation 2012-2013, Germany, Employment Protection Database 2013, p. 35; O. Stettes, Germany: The Role of Governments...

72 P. Haan, V. Steiner, Making Work Pay for the Elderly Unemployed: Evaluating Alternative Policy Reforms for Germany, "IZA Discussion Paper” 2006, November, no. 2424, p. 7.

73 B. Ebbinghaus, W. Eichhorst, Employment Regulation..., p. 13.

74 B. Kraemer, Germany: Working Life Country Profile...

75 OECD, Ageing and Employment Policies..., p. 114.

76 OECD, Detailed Description of Employment Protection Legislation 2012-2013, Denmark, Employment Protecton Database 2013, p. 21.

77 Z. Cseres-Gergely, Hungary, EEO Review..., p. 7. 
the number of the unemployed has increased significantly, while the number of officials employed in the labour offices has not changed. ${ }^{78}$ Less than $1 / 5$ of the unemployed have had contact with customer advisers, because the obligation to cooperate with the authorities was not sufficiently enforced. Meetings carried out, in most cases on a quarterly basis, did not reinforce the motivation to seek employment. ${ }^{79}$ Public employment services offer training to the unemployed, those covered by the vocational rehabilitation system, and certain employees who benefit from specific employment support programs. ${ }^{80}$ Training can be combined with the reimbursement of travel, accommodation and examination costs, and the payment of training grants for the unemployed or training allowances for employees. While participation in training is available to all interested persons, financial support is only for vulnerable groups in the labour market, especially those over 50 years of age. ${ }^{81}$ Training is provided by both private and public entities. Due to the significant share of training programmes in the budget of the National Employment Fund, the resources allocated for their implementation have been significantly reduced. ${ }^{82}$

Instruments affecting older people in the labour market include vocational rehabilitation. They are not only addressed to this age group, as the average age of participants is 50 . A close relationship between aging and incapacity for work has been observed. Before a person is entitled to incapacity benefits, he/she is required to undergo a rehabilitation process, including counseling and training provided by public employment services. At the end of this process a person is directed to employment on an open or protected labour market. Employers can apply for co-financing for maintaining and creating new jobs for these employees. ${ }^{83}$

On the other hand, public employment services in Germany start their activities by recognizing the barriers to employment, primarily using a profiling technique which helps to determine the strengths and weaknesses of a particular person. The age of a person is only one of the factors taken into account at that time. For this reason, German legislation does not provide for vocational rehabilitation measures directed exclusively to the older unemployed. ${ }^{84}$ The measures undertaken by the public employment services for older unemployed are primarily focused on assistance tailored to the individual's obstacles to employment and to the both

78 Ibidem; L. Bodis, The Quality of Policy Making, [in:] K. Fazekas, A. Scharle. (eds.), From Pensions to Public Works. Hungarian Employment Policy from 1990 to 2010, Budapest 2012, p. 105.

79 K. Fazekas, A. Scharle, Diagnosis and Lessons, [in:] K. Fazekas, A. Scharle (eds.), From Pensions to Public Works..., p. 5.

80 Z. Cseres-Gergely, Hungary, EEO Review..., p. 6.

81 Ibidem.

82 Ibidem, p. 6.

83 Ibidem, p. 8; A. Kiss, P. Belyó, A. Kunert, M. Komiljovics, K. György, Hungary: Working Life Country Profile.

84 M. Paluszkiewicz, Wybrane środki prawne wspierające bezrobotne osoby starsze w podjęciu zatrudnienia w Niemczech, p. 32 and the literature cited therein. 
stabilization of employment and redressing of weaknesses, in particular due to inadequate professional qualifications. ${ }^{85}$ Moreover, public employment services were obliged to cooperate with those temporaryemployment agencies which provide personal services, who guide the unemployed sent by the labour office to employment. The targeted individuals are those who face particular difficulties in taking up employment, including older unemployed persons. These agencies, in addition to workplace placements, also provide appropriate training to increase employment opportunities, the employment costs of which are partially subsidized through public funds. For employment, agencies receive a bonus based on local unemployment rates, and on an individual's barriers to employment. ${ }^{86}$

In 2005, the Minister for Labour and Social Affairs launched the Perspective $50+$ program - a regional employment pact for older workers. Its aim was to create better employment opportunities for older people by activating local and regional labour market actors. The goal was to stimulate and reintegrate older people, raise awareness of the barriers to taking on or continuing the employment of older people, tackling stereotypes about employing older workers, and promoting good practices in this area. It is worth mentioning that the emphasis here is primarily on the integration of older people into the so-called primary labour market, and therefore, preferably in the form of non-subsidized employment, which is includes social insurance. For this reason, employers, their organizations, trade unions, municipalities, churches and other non-profit organizations could be involved in the creation and implementation of regional pacts. In practice, local employment agencies and local labour offices dealing with the longterm unemployed were also engaged.$^{87}$

In turn, in Denmark, special attention is paid to the frequent contact of the unemployed with the public employment services, which makes it possible to significantly shorten the period of unemployment. ${ }^{88}$ In addition, an accurate assessment of an individual's predispositions influences the efficiency of the job search and enables them to find employment that is adequate to the individual characteristics of a person. ${ }^{89}$ Therefore, one of the most important measures used to counter

85 Bundesagentur..., p. 21.

86 J. Leschke, G. Schmid, D. Griga, On the Marriage of Flexibility and Security: Lessons from the Hartz-reforms in Germany, "Wissenschaftszentrum Berlin für Sozialforschung (WZB) Discussion Paper" 2006, April, pp. 10-11.

87 M. Paluszkiewicz, Wybrane środki prawne wspierajace bezrobotne osoby starsze w podjęciu zatrudnienia w Niemczech, pp. 36-37 and the literature cited therein.

88 P. K. Madsen, EEO Review..., p. 6; OECD, Ageing and Employment Policies..., p. 14; M. Rosholm, M. Svarer, J. M. Pedersen, Why is Unemployment so Low in Denmark?, Evidence from Four Social Experiments, Paper presented at the EEA-ESEM 2012 Conference, p. 11; T. Büchring, Denmark: New Reform Targets Unemployment, Dublin 2014, http:// www.eurofound.europa.eu/observatories/eurwork/articles/labour-market-social-policies/denmark-new-reform-targets-unemployment, (accessed: 29.07.2016).

89 M. Paluszkiewicz, Wybrane środki prawne wspomagajace powrót bezrobotnych osób starszych na rynek pracy w Danii..., pp. 191-192 and the references cited therein. 
long-term unemployment, which occurs on a fairly large scale among the older unemployed, is so-called profiling. ${ }^{90}$ The literature points to three basic forms of unemployment assistance. These are counseling and retraining, workplace training and subsidized employment. ${ }^{91}$ Of these, training in the workplace and all forms of improving professional qualifications during employment prove to be the most effective activation measures. ${ }^{92}$

In respect of persons aged 60 or over, public employment services are required to take specific measures that would enable rapid professional activation. ${ }^{93} \mathrm{~W}$ ithin the first 3 months, an older unemployed person entitled to unemployment benefits has the opportunity to participate in his or her chosen labour market program. ${ }^{94}$ Unemployed people over 60 and under 30 are given priority in this respect, unemployed people from other age groups have the opportunity to participate in the selected program during the first 6 months of unemployment. ${ }^{95}$ Participation in them is compulsory for the unemployed 96 and, if necessary, participation may be repeated. ${ }^{97}$ These programs usually included assistance in finding employment, ${ }^{98}$ vocational guidance and training. 99

In Belgium, the procedure for assisting unemployed people in seeking employment is not dependent on their age. Every unemployed person is obliged by the public employment service to actively search for a job for at least one year. However, a determination of the obstacles to employment is performed 21 months after registration as unemployed. Depending on this, an individual action plan is formulated. Its failure does not, however, entail negative consequences for the person involved. A follow-up action plan, whose failure results in specific sanctions such as partial or full suspension of the right to unemployment benefits, is then established. This procedure is supported and complemented by the various services offered by the regional employment services, in the form of vocational guidance and job matching. 100

90 M. Rosholm, M. Svarer, B. Hammer, A Danish Profiling System, "IZA Discussion Paper" 2004, November, no. 1418, p. 1.

91 T. M. Andersen A Flexicurity..., p. 123.

92 Ibidem, p. 136.

93 P. K. Madsen, EEO Review..., p. 2.

94 Ibidem, p. 6; M. Rosholm, M. Svarer, J.M. Pedersen, Why is Unemployment..., p. 11; OECD, Ageing and Employment Policies..., p. 141.

95 Ibidem, p. 141.

96 P. K. Madsen, EEO Review..., p. 6.

97 M. Rosholm, M. Svarer, J. M. Pedersen, Why is Unemployment..., p. 11.

98 B. K. Graversen, J.C. van Ours, How to Help Unemployed Find Jobs Quickly: Experimental Evidence from a Mandatory Activation Program, "IZA Discussion Paper" 2006, December, no. 2504, p. 8.

99 Ibidem.

100 More details: M. Paluszkiewicz, Wybrane środki prawne wspomagajace powrót bezrobotnych osób starszych na rynek pracy w Belgii, pp. 117-118 and the literature cited therein. 


\section{Legal measures to mitigate the effects of unemployment in Belgium, Denmark, Germany and Hungary}

In Hungary, the unemployment insurance provides the older unemployed people with special unemployment benefits. Those who have already lost or will soon lose their entitlement to unemployment benefits and, in addition, will soon meet the conditions required to obtain a pension, are entitled to it. ${ }^{1}$ The benefit is paid until the entitlement to a retirement pension or until the acquisition of disability pension as part of average earnings of the entitled person, not more than $40 \%$ of the minimum wage. ${ }^{2}$ It is worth noting that the person collecting the benefit can take up employment and this does not affect either the right to benefit or the amount thereof. ${ }^{3}$

The main benefit, however, coming from unemployment insurance is unemployment benefit. The basis of allowance is a fixed portion of the average earnings of the last four quarters of employment, but not more than the amount of the minimum wage. ${ }^{4}$ If the average salary of the entitled person can not be determined, the amount of benefit is set at $130 \%$ of the national minimum wage. Benefit is paid at the rate of 1 day for every 10 days of insurance. This means that the shortest term of benefits is 36 days, while the longest is 90 days. ${ }^{5}$ The allowance is paid without a waiting period. ${ }^{6}$ Short-term employment, lasting up to 120 days, does not result in the loss of entitlement to benefit. ${ }^{7}$ It may be lost, however, if caused by not keeping the home and the garden in proper order, and the situation where the child of an unemployed person is has unreasonable absences at school. ${ }^{8}$ After the exhaustion of the right to unemployment benefits, a person is entitled to certain social assistance benefits. ${ }^{9}$

In Germany two benefits have been established to mitigate the effects of unemployment - type I and type II unemployment benefits. Older unemployed people receive

1 MISSOC, Your Social Security Rights in Hungary, European Commission 2013 Brussels, p. 29.

2 MISSOC, Comparative Tables, Hungary, Unemployment, Benefits for Older Unemployed (as of 1.07.2016).

3 MISSOC, Your Social Security Rights in Hungary, p. 29.

4 MISSOC, Comparative Tables, Hungary, Unemployment. Rates of Benefits (as of 1.07.2016).

5 MISSOC, Comparative Tables, Hungary, Unemployment. Duration of Benefits (accessed: 1.07.2016).

6 MISSOC, Comparative Tables, Hungary, Unemployment, Waiting Period (accessed: 1.07.2016).

7 MISSOC, Comparative Tables, Hungary, Unemployment, Cumulation with Earnings from Work (accessed: 1.07.2016).

8 D. Szikra, Democracy..., pp. 7 and 11.

9 A. Scharle, Activation and Wage Adjustments, [in:] K. Fazekas, A. Scharle (eds.), From Pensions to Public works... p. 134; M. Frey, The Legal and Institutional Environment of the Hungarian Labour Market, [in:] Fazekas K., Lovasz A., Telegdy A. (eds.), The Hungarian Labour Market. Review and Analysis 2010, Budapest 2010, pp. 210-211. 
type I benefit from unemployment insurance for a longer period of time than younger people if they have the required length of insurance. The period in this case is between 15 and 24 months. The amount depends on the average salary in the last year and the family situation. ${ }^{10}$ Type II unemployment benefit is financed from public funds and the pay period is generally not limited. ${ }^{11}$ It is applied after exhaustion of the right to type I benefit or if a person does not have the required length of insurance. ${ }^{12}$ It is a fixed flatrate and depends on the individual material situation and not the last earnings. ${ }^{13}$

In Denmark, unemployment insurance is voluntary, yet about $75 \%$ of the work force is covered. ${ }^{14}$ Duration of unemployment payment is not affected by age. The benefit period for persons aged 55 or over was reduced from 48 to 24 months. ${ }^{15}$ In return, a number of additional allowances were established, in particular "senior job" that was already described. ${ }^{16}$ In total, the time period of receiving the allowance and temporary social benefits can not exceed 4 years. ${ }^{17}$ The amount of benefit is determined in relation to the final salary, including the daily limit in a five-day working week. ${ }^{18}$

Unemployment benefits in Belgium are subject to indefinite periods of time, provided that certain conditions have been met. This solution has been criticized by various international organizations, among others the OECD. The amount of unemployment benefit is determined on the basis of the most recent gross salary, the family situation and the duration of unemployment. Persons who had reached the age of 55 and who had met the required conditions were covered. At present, those entitled are employees who are made redundant from work due to restructuring, employees performing burdensome work, and employees with long-term work experience. The amount received depends on the unemployed person's family situation and his/her age. ${ }^{19}$

10 MISSOC, Comparative Tables, Germany. Unemployment, Earnings Taken as Reference and Ceiling (accessed: 1.07.2016).

11 S. Vogel, Germany: Social Partners Involvment in Unemployment Benefit Regimes, Dublin 2012, http://www.eurofound.europa.eu/observatories/eurwork/comparative-information/national-contributions/germany/germany-social-partners-involvement-in-unemployment-benefit-regimes, (accessed: 13.07.2016).

12 MISSOC, Comparative Tables, Germany: Unemployment. Main Conditions, (as of 1.07.2016).

13 MISSOC, Comparative Tables on Social Protection, Germany, Unemployment, Rates of the benefits, (accessed: 1.07.2016); A. Kemmerling, O. Bruttel, New Politics in German Market Policy? The Implications of the Recent Hartz Reforms for the German Welfare State, "Wissenschaftszentrum Berlin für Sozialforschung (WZB) Discussion Paper” 2005, February, p. 8.

14 OECD, Assessment and Key Recommendations..., p. 4.

15 Ibidem, p. 2.

16 OECD, Ageing and Employment Policies..., p. 73. M. Barslund, National Report for Denmark. Mobilising the Potential of Active Ageing in Europe (MoPAct), Centre for European Policy Studies (CEPS) 2013, p. 4; OECD, Thematic Follow-up..., p. 2.

17 OECD, Ageing and Employment Policies...., p. 73.

18 MISSOC, Comparative Tables Denmark, Unemployment, Total Unemployment. Rates of Benefits (as of 1.06.2016).

19 European Commission, Belgium - Unemployment, Employment, Social Affairs \& Inclusion, http://ec.europa.eu/social/main.jsp?catld=1102\&langld=en\&intPageld=4425, (accessed: 7.04.2016). 


\section{An outline of the position of older people on the Polish labour market}

The employment relationship model is centralized in Poland. The main role in regulating employment relations is assigned to the extensive labour legislation, which consists of the Labour Code ${ }^{1}$ and numerous laws and regulations. Social dialogue is focused mainly at the central level ${ }^{2}$ and includes fixing the minimum wage for work, ${ }^{3}$ national socio-economic policies and legislative changes. ${ }^{4} \mathrm{Col}-$ lective agreements dominate primarily at the company level, much less frequently at the industry level. The main reason for this is the various financial condition of employers belonging to the same industry as well as the difficulty of selecting partners (parties) for such agreements. ${ }^{5}$ Cross-institutional arrangements apply in some sectors of the economy only. 6 The level of unionization of employees is also not high. According to the 2014 data, trade union members accounted for $11 \%$ of all working people, including $17 \%$ of those employed on the basis of an employment relationship. ${ }^{7}$

Because of the economic system in Poland and the few links with the economies of capitalist countries, the economic crises of the 1970s and 1980s did not affect the level of unemployment in this country. However unemployment occurred on a large scale, just as in the case of Hungary, only a few years after the initiation of the political transformation. The registered unemployment rate in June 1996 was $14.3 \% .{ }^{8}$ In the first period after the unemployment problem was revealed, the legislator attempted to create appropriate legal instruments

1 Which taxonomy is very extensive. The Labour Code refers primarily to regulating an individual employment relationship, but also regulates in part the issues of collective and procedural labour law.

2 Until September 11, 2015, the Tripartite Commission for Socio-Economic Affairs and now the Council for Social Dialogue - the Act of July 24th, 2015 on the Council for Social Dialogue and other institutions for social dialogue, Journal of Laws, item. 1240 as amended.

3 Article 2 (1) of the Act on the Minimum Remuneration for Work, consolidated Journal of Laws 2017, item 847.

4 J. Wratny, Rada Dialogu Społecznego. Czy jeszcze instytucja zbiorowego prawa pracy?, "Praca i Zabezpieczenie Społeczne" 2016, no. 10, pp. 4-5.

5 G. Goździewicz, Wpływ działań zbiorowych na indywidualne stosunki pracy, [in:] H. Lewandowski (ed.), Polskie prawo pracy w okresie transformacji w oświetleniu prawa wspólnotowego, Warszawa 1997, p. 99.

6 According to data at the end of 2014, they were included specifically for employees in the power industry, mining, defense and aerospace industry, and some employees of local government and budgetary units, http://www.dialog.gov.pl/dialog-krajowy/ uklady-zbiorowe-pracy/, (accessed: 28.06.2017).

7 Główny Urząd Statystyczny, Związki zawdowe w Polsce w 2014 r. Notatka informacyjna, Warszawa 2015, p. 5.

$8 \quad$ Z. Góral, M. Włodarczyk, Prawne problemy rynku pracy, pp. 149-150. 
to counteract this phenomenon. Their poor effectiveness can be confirmed by the limited duration of the regulation - the Employment Act of December 29th, $1989^{9}$ was replaced after less than two years by the Employment and Unemployment Act of October $16^{\text {th }}, 1991 .{ }^{10}$ Not including a prohibition on the dismissal of pre-retirement workers, ${ }^{11}$ the policy on counteracting unemployment among older people was primarily based on social benefits, ${ }^{12}$ as was the case in Hungary, Belgium and Germany. An example may be the solution of extending the period of unemployment benefits until the acquisition of the right to a pension for persons who were less than 2 years from reaching statutory retirement age and had the required length of service, or persons who, on a basis of service, were qualified for an old-age pension but who were aged 5 years less than the statutory retirement age at the time of termination of employment for the employer-related reasons, eg. economic grounds. ${ }^{13}$ Another law on employment and counteracting unemployment of December $14^{\text {th }}, 1994^{14}$ provided older unemployed persons with benefits such as: pre-retirement allowance ${ }^{15}$ or pre-retirement benefits. ${ }^{16}$ Its amendments have brought positive changes in the form of introducing the first active measures addressed at the older unemployed. These were public works lasting up to 24 months for women who were 53 years old and men who were 58 years old. 17

9 Journal of Laws No. 75, item 446.

10 Journal of Laws No. 106, item 457.

11 Article 39 of the Labour Code, which then envisaged a two-year protection period. Since January 1, 2004 it has been extended to 4 years.

12 The main regulations in this area were: Regulation of the Minister of Labor and Social Policy of 26 January 1990 on early retirement of employees dismissed from work for the employer-related reasons (Journal Of Laws No. 4, item 27); Regulation of the Council of Ministers of March 25th, 1997 on the principles of early retirement of employees dismissed from work for the employer-related reasons (Journal of Laws No. 29, item 159).

13 Article 21 (5) of the Act of 16 October 1991 on Employment and Unemployment; more details W. Sanetra, Komentarz do art. 21, [in:] Zatrudnienie i bezrobocie. Przepisy i komentarz, Warszawa 1993, pp. 107-108; Z. Góral, M. Włodarczyk, Komentarz do art. 21, [in:] Komentarz do ustawy z dnia 16 października 1991 r. o zatrudnieniu i bezrobociu, Łódź 1992, pp. 68-69.

14 Journal of Laws 1995, No 1, item 1.

15 Article 37j added to the Act of December 14 $4^{\text {th }}, 1994$ on Employment and Counteracting Unemployment by the amending act of 6 December 1996, Journal of Laws No 147, item 687 , granted in 1997-2001.

16 During the period 1997-31.05.2004 on the basis of Art. 37j of the Act of 14 December 1994 on Employment and Counteracting Unemployment, consolidated text Journal of Laws 2003 No. 58, item. 514 as amended It is still granted, but under more stringent conditions, under the Act of 30 April 2004 on pre-retirement benefits, consolidated text Journal of Laws 2013, item 170 as amended.

17 Art. 19 (2a) added by the Act of December 20th, 2002 amending the Act on Employment and Counteracting Unemployment and the Act on the Education System, Journal of Laws 2003, No. 6, item 65. More details Z. Góral, Komentarz do art. 19 ustawy 
The situation of older people on the labour market deteriorated considerably in the early 2000s. In 2002, the overall unemployment rate reached its highest level of $20 \% .{ }^{18}$ This was mainly due to the weakening of overall economic growth dynamics between 1998-2003. ${ }^{19}$ Over the period 2002-2005, the unemployment rate among persons aged 50-64 exceeded $13 \%{ }^{20}$ To complement this bleak picture, it should be added that in the indicated age group the employment rate in 2004 was only $37.9 \%{ }^{21}$ This state of affairs was only partly due to the economic slowdown. The low level of professional activity of older people was the consequence of the institutional arrangements adopted at the time, such as early retirement pensions, pre-retirement benefits and easily accessible incapacity benefits. In the literature it is indicated that in the years 1999-2004 on average circa 4 million persons in pre-retirement age benefited from the aforementioned benefits. ${ }^{22}$ This situation prompted decision-makers to take measures to improve the situation of the older in the labour market. In 2004, the Ministry of Economy and Labour adopted the 50 Plus program, which consisted of pilot projects targeting unemployed older people. However, it had a small number of beneficiaries. ${ }^{23}$ More coherent actions were designed within the national ${ }^{24}$ Program $45 / 50$ plus, ${ }^{25}$ whose implementation was based on the assumptions of the National Reform Programs. ${ }^{26}$ Its aim is to restore the employability of unemployed persons in the above mentioned age

o zatrudnieniu i przeciwdziałaniu bezrobociu, [in:] Z. Salwa (ed.) Prawo pracy, Warszawa 2004, p. 100.

18 http://ec.europa.eu/eurostat/web/products-datasets/-/lfsa_urgaed, (accessed: 27.06.2017).

19 E. Kwiatkowski, Kluczowe wyzwania dla polskiego rynku pracy, [in:] E. Kwiatkowski, L. Kucharski (eds.), Rynek pracy w Polsce - tendencje, uwarunkowania i polityka państwa, Łódź 2010, p. 18.

20 http://ec.europa.eu/eurostat/web/products-datasets/-/Ifsa_urgaed, (accessed: 27.06.2017).

21 http://ec.europa.eu/eurostat/web/products-datasets/-/lfsa_ergan, (accessed: 27.06.2017).

22 E. Kwiatkowski, Kluczowe wyzwania dla polskiego rynku pracy..., pp. 22-24 and the literature cited therein.

23 More details: A. Podgórniak-Krzykacz, J. Przywojska, Krajowe i regionalne programy rynku pracy wobec aktywizacji zawodowej osób w wieku 50+/45+, [in:] Urbaniak B., Wiktorowicz J. (eds.), Raport z analizy programów skierowanych do osób 50+ zrealizowanych w Polsce w latach 2004-2009, Łódź 2011, p. 72.

24 For other types of programs, see H. Sobocka-Szczapa (ed.), I. Poliwczak, Diagnoza sytuacji osób w wieku 45+ na rynku pracy w Polsce i wybranych krajach Unii Europejskiej. Aspekt ekonomiczny, Łódź 2011; A. Podgórniak-Krzykacz, J. Przywojska, Krajowe i regionalne...

25 Ministerstwo Pracy i Polityki Społecznej, Program 45/50 Plus, Program działań na rzecz promocji zatrudnienia, łagodzenia skutków bezrobocia i aktywizacji zawodowej osób w wieku niemobilnym, Warszawa 2008, http://psz.praca.gov.pl/documents/10828/182467/Program\%2045-50\%20PLUS.pdf/6a7ead58-71ca-46e5-bac749901c557cc9? $\mathrm{t}=1403859201000$, (accessed: 28.06.2017).

26 More details: A. Podgórniak-Krzykacz, J. Przywojska, Krajowe i regionalne..., pp. 6566; H. Sobocka-Szczapa (ed.), I. Poliwczak, Diagnoza..., p. 122. 
category, through activation measures which enable them to take up and maintain employment. As part of the program, public employment services were expected to create projects that activate older unemployed people using individual plans and labour market services and instruments. This program also has a small number of beneficiaries (about 2 thousand people a year). ${ }^{27}$

A more systemic approach to the issue of older unemployed persons has been reflected in the 2008 government program the "Solidarity of Generations". Actions to increase the professional activity of the $50+$ persons". ${ }^{28}$ The main objective is to reach an employment rate of $50 \%$ in the 55-64 age group by 2020 . Among the specific objectives adopted for implementation were the improvement of employment conditions (adaptation of working conditions, flexible organization of work, preventive healthcare), the promotion of the employment of over 50s, the improvement of competences and qualifications (support for lifelong learning), reduction of the costs of their employment (exemption from the financing of certain contributions, refund of training costs, reduction of time of the payment of sick pay), vocational activation of the unemployed or persons at risk of job loss (dissemination of labour market programs, creation of individual support programs). ${ }^{29}$ Access to the extensive early retirement system was also reduced, ${ }^{30}$ as well as the phasing out of early-retirement pensions for those persons working under specific conditions or circumstances. ${ }^{31}$ The source of funding is the Labour Fund and the European Social Fund under the Human Capital Operational Program (2007-2013). ${ }^{32}$

Due to its weaker international relations than in other EU countries, the Polish economy was less affected by the effects of the 2008 economic crisis. ${ }^{33}$ However, the unemployment rate among older persons in 2010-2013 was still above 7\%. This triggered a reaction from the government, leading to the amendment of the "Solidarity of Generations" program in 2014. ${ }^{34}$ In the newer version, it simultaneously

27 H. Sobocka-Szczapa (ed.), I. Poliwczak, Diagnoza..., pp. 122-124.

28 Resolution of the Council of Ministers of 17 October 2008, http://www.mpips.gov.pl/ bip/akty-prawne/programy/program-solidarnosc-pokolen-dzialania-dla-zwiekszenia-aktywnosci-zawodowej-osob-w-wieku-50/, (accessed: 27.06.2017).

29 Program of the Council of Ministers, Solidarność pokoleń. Działania dla zwiększenia aktywności zawodowej osób w wieku 50+, Warszawa 2008, pp. 13-21.

30 The right to it could be generally acquired by the end of 2008 , with benefits covered primarily by Articles $29-50$ of the Act of December $17^{\text {th }}, 1998$ on pensions from the Social Insurance Fund, consolidated text Journal of Laws 2016, item 887 as amended, as well as early retirement for teachers and other occupational groups regulated by separate regulations.

31 Law of 19 December 2008 on bridging pensions, consolidated text Journal of Laws 2017, item 664.

32 Program of the Council of Ministers, Solidarność pokoleń, pp. 29-30.

33 A. Organiściak-Krzykowska, Współczesne problemy polskiego rynku pracy na tle krajów UE, [in:] E. Kwiatkowski, L. Kucharski (eds.), Rynek pracy w Polsce - tendencje, uwarunkowania i polityka państwa, Łódź 2010, p. 34.

34 Attachment to the Resolution of the Council of Ministers No. 239 of December, 24th, 2013 on the setting up of the Solidarity of Generations program. Działania na rzecz 
developed the assumptions adopted in the field of vocational activation under the Senior Policy for the years 2014-2020. ${ }^{35}$ Its task is also to support the achievement of the objectives set out in the Strategy "Poland 2030", 36 and especially the development of human capital through increased employment and the creation of a workbased state (society) (workfarestate). ${ }^{37}$ Detailed goals include: improving the qualifications of the over 45s (taking into account the needs of the labour market), creating friendly working environments for older workers, promoting the employment of older workers and the idea of active aging, and developing cooperation for increasing the employment of older workers. Reforms also include a system of labour administration, especially within the set of instruments used in the labour market, as well as in terms of improving the quality and efficiency of the services provided. ${ }^{38}$

Among the reasons for the amendment of the program "Solidarity of Generations", was the process of increasing the retirement age. The was due to the serious financial difficulties of the pension system, unfavorable demographic phenomena and intensified labour migration of Poles to other EU countries. As a result of the changes introduced in 2013, the statutory retirement age was to be equalized for both genders and raised from 60 years for women and 65 years for men to 67 years (in 2040 for women and in 2020 for men). ${ }^{39}$ The lack of institutional arrangements to support the prolongation of professional activity and the return of unemployed older people to the labour market has amplified general social discontent, which has been used as an important argument in political campaigns. As a result, in 2016, the statutory retirement age pension reform was halted - as of October $1^{\text {st }}, 2017$, it will be seperated on the basis of the gender criterion and reduced to 60 years for women and 65 years for men. ${ }^{40}$ This will certainly improve the unemployment statistics of older people but will undermine the production capacities of the Polish economy.

zwiększenia aktywności zawodowej osób w wieku 50+, Ministry of Labour 2014, item 115. It creates a basis for actions for the broader social activation of older people, along with the Long-term Senior Policy in Poland for the years 2014-2020, annexed to Resolution of the Council of Ministers No. 239 of 24 December 2013 on the establishment of the Solidarity of the Generations Program. Działania na rzecz zwiększenia aktywności zawodowej osób w wieku 50+, Ministry of Labour. 2014, item 52.

35 Annex to Resolution of the Council of Ministers No. 238 of December $24^{\text {th }}, 2013$ on the adoption of the Long-term Senior Policy in Poland for the years 2014-2020, Ministry of Labour 2014, item 118.

36 Resolution No. 16 of the Council of Ministers of February $5^{\text {th }}, 2013$ on the adoption of the Long-Term National Development Strategy. POLSKA 2030. Trzecia Fala Nowoczesności, Ministry of Labour, item. 121.

37 Solidarność pokoleń. Działania dla zwiększenia aktywności zawodowej osób w wieku 50+, Ministry of Labour 2014, item 115, p. 26.

38 The Act of March 14th 2014 amending the act on promotion of employment and labour market institutions and amending certain other acts, Journal of Laws, item 598.

39 Article 1 (5) of the Act of May 11 $11^{\text {th }}, 2012$ on the amendment of the law on pensions from the Social Insurance Fund, Journal of Laws, item 637.

40 Article (5) of the Act of November 16 th, 2016 on the amendment of the law on pensions from the Social Insurance Fund and some other acts, Journal of Laws 2017, item 38. 
The assumptions adopted under the aforementioned program "Solidarity of Generations" were partially fulfilled under the Act of April $20^{\text {th }}, 2004$ on the promotion of employment and labour market institutions. ${ }^{41}$ Article 2 (1) pt. 4 of this law introduced a legal definition of the unemployed over 50 years old, 42 although legislation had already dealt with solutions related to the employment of older people. ${ }^{43}$ At the same time, unemployed persons over 50 were classified as "persons in a special situation on the labour market". 44 This was due to the observation made by the legislator that some people are more likely to lose their jobs than other labour market participants, which justifies the use of a specific legal instrument for that particular group. ${ }^{45}$ Given these inequalities on the labour market, the differentiation of their legal status becomes a necessary condition for their equal treatment by the legislator. ${ }^{46}$ The above assumptions are implemented primarily by references in hypotheses of individual legal norms to specific categories of persons who are in a special situation on the labour market, and therefore also to the unemployed over the age of 50 . In addition, the measures provided for all the unemployed also relate to the over 50s. Turning to the very general characteristics of legal instruments addressed directly to unemployed older people, it should be pointed out that they have recently benefited from priority in their favor from public employment services - a proposal for adequate employment, other paid work, training, vocational internship, adult vocational training, intervention or public work had to be presented to them within 6 months of the date of registration. ${ }^{47}$ At present, an older

41 The original text, Journal of Laws No. 99, item 1001. Consolidated text 2017, item 1065, hereinafter the act on promotion of employment.

42 This is an unemployed person who has completed at least 50 years in the calendar year of applying of employment services or instruments. More details Z. Góral, Komentarz do art. 2, [in:] Z. Góral (ed.), Ustawa o promocji zatrudnienia i instytucjach rynku pracy. Komentarz, Warszawa 2016, pp. 56-89.

43 More details: M. Paluszkiewicz, Wyrównywanie szans pracowników starszych w zatrudnieniu $w$ świetle prawa międzynarodowego a prawo polskie, "Praca i Zabezpieczenie Społeczne" 2012, no. 12, p. 11.

44 Article 49 (3) of the Act on Promotion of Employment; more details E. Staszewska, Status prawny osób bezrobotnych z grup szczególnego ryzyka, "Polityka Społeczna” 2005, no. 1, pp. 10-12; eadem, Pojęcie "osób będących w szczególnej sytuacji na rynku pracy" w świetle ustawy o promocji zatrudnienia i instytucjach rynku pracy, "Zeszyty Prawnicze UKSW” 2010, vol. 10.1, passim; eadem, Komentarz do art. 49, [in:] Z. Góral (ed.), Ustawa o promocji zatrudnienia i instytucjach rynku pracy. Komentarz, pp. 507-508.

45 Cf. M. Szylko-Skoczny, Polityka spoteczna wobec bezrobocia w Trzeciej Rzeczypospolitej, Warszawa 2004, p. 225.

46 More details: Z. Góral, Dyferencjacja statusu prawnego bezrobotnych, [in:] M. Matey-Tyrowicz, L. Nawacki, B. Wagner (eds.), Prawo pracy a wyzwania XXI-go wieku: księga jubileuszowa Profesora T. Zielińskiego,Warszawa 2002, pp. 196-197.

47 Article 50 (1) of the Act on Promotion of Employment, version in force until 27 May 2014. Cf. E. Staszewska, Komentarz do art. 50, [in:] Z. Góral (ed.), Ustawa o promocji zatrudnienia i instytucjach rynku pracy. Praktyczny komentarz, Warszawa 2011, p. 339; M. Włodarczyk, M. Paluszkiewicz, Formy prawne wyrównywania szans osób 50+/45+na rynku 
unemployed person is obliged, like the rest of the unemployed, to apply to the relevant labour office at the time appointed by the office to confirm their willingness to take up employment ${ }^{48}$. As a category of people particularly vulnerable to unemployment, older people may also be covered by special programs, ${ }^{49}$ public works 50 as well as schemes available to all unemployed - training, ${ }^{51}$ internships, ${ }^{52}$ vocational preparation of adults, 53 job matching, 54 professional guidance, 55 and labour market instruments. ${ }^{56}$ For unemployed older people, a loan is also available ${ }^{57}$ and a non-repayable subsidy for starting a business. ${ }^{58}$ The application of specific measures is determined by the assistance profile established for a particular unemployed person ${ }^{59}$ and the individual action plan based on it. ${ }^{60}$ Among measures to counteract unemployment among older people, one can also name instruments

pracy w Polsce, [in:] B. Urbaniak, J. Wiktorowicz (eds.), Raport z analizy programów skierowanych do osób 50+ zrealizowanych w Polsce w latach 2004-2009, Łódź 2011, p. 41.

48 Article 33 (3) of the Act on Promotion of Employment.

49 Articles 66a-66b of the Act on Promotion of Employment. More details A. Wasilewska, H. Rogala, Programy specjalne - szansa, która czeka na wykorzystanie, "Służba Pracownicza” 2012, no. 3, pp. 16-22; M. Paluszkiewicz, Komentarz do rozdziału 13a, [in:] Z. Góral (ed.), Ustawa o promocji zatrudnienia i instytucjach rynku pracy. Komentarz, pp. 707-717.

50 Article 59 of the Act on Promotion of Employment, more details E. Staszewska, Komentarz do art. 59, [in:] Z. Góral (ed.), Ustawa o promocji zatrudnienia i instytucjach rynku pracy. Komentarz, pp. 599-600; M. Włodarczyk, M. Paluszkiewicz, Formy prawne..., p. 42.

51 Articles 40-42a of the Act on Promotion of Employment, E. Bielak-Jomaa, Komentarz do art. 40-42a, [in:] Z. Góral (ed.), Ustawa o promocji zatrudnienia i instytucjach rynku pracy. Komentarz, pp. 407-438.

52 Article 53 of the Employment Promotion Act, E. Staszewska, Komentarz do art. 53, [in:] Z. Góral (ed.), Ustawa o promocji zatrudnienia i instytucjach rynku pracy. Komentarz, pp. 547-565.

53 Art. 53a-53m of the Act on Promotion of Employment, E. Staszewska, Komentarz do art. 53a-53m, [in:] Z. Góral (ed.), Ustawa o promocji zatrudnienia i instytucjach rynku pracy. Komentarz, pp. 563-582.

54 Art. 36-36a of the Act on promotion of employment, M. Włodarczyk, Komentarz do art. 36-36a, [in:] Z. Góral (ed.), Ustawa o promocji zatrudnienia i instytucjach rynku pracy. Komentarz, pp. 352-381.

55 Article 38 of the Employment Promotion Act, E. Staszewska, Komentarz do art. 38, [in:] Z. Góral (ed.), Ustawa o promocji zatrudnienia i instytucjach rynku pracy. Komentarz, pp. 393-403.

56 Chapter 11 of the Act on Employment Promotion, broadly on this subject T. Wrocławska, Komentarz do rozdziału 11, [in:] Góral Z. (ed.), Ustawa o promocji zatrudnienia i instytucjach rynku pracy. Komentarz, pp. 443-507.

57 Article $61 \mathrm{i}$ of the Act on promotion of employment.

58 Article 46 (1) (2) of the Act on promotion of employment.

59 Article $33(2 \mathrm{~b}-2 \mathrm{c})$ of the Act on promotion of employment, Z. Góral, Komentarz do art. 33, [in:] Z. Góral (ed.), Ustawa o promocji zatrudnienia i instytucjach rynku pracy. Komentarz, pp. 315-319.

60 Article 34a of the Act on promotion of employment, Z. Góral, Komentarz do art. 33, [in:] Z. Góral (ed.), Ustawa o promocji zatrudnienia i instytucjach rynku pracy. Komentarz, pp. 346-347. 
that provide financial incentives for employers on the open labour market, such as permanent or temporary exemptions from contributions to the Labour Fund 61 and the Guaranteed Employee Benefits Fund. ${ }^{62}$ Limiting the characteristics of benefits that mitigate the effects of unemployment only to unemployment benefits, it should be noted that the structure of this benefit is directly and indirectly related to the biological age of the unemployed. For persons who have reached the age of 50 and have at least 20 years of entitlement to unemployment benefit, this benefit shall be 365 days, which is 185 days longer than in the case of the majority of unemployed. ${ }^{63}$ In addition, unemployed persons with a minimum of 20 years' entitlement to benefits, receive $120 \%$ of the basic amount. ${ }^{64}$

Polish legislation also provides for measures to support the employment of older workers. In this case the solution is addressed directly to the aforementioned category by the appeal of biological age, usually 45 or 50 years, and indirectly, by referring to the acquisition of pension rights. Among them a shorter period of sick pay 65 or the already mentioned prohibition of termination of the employment contract for the 4 years before reaching the statutory retirement age if the employment period allows the employee to obtain the right to a retirement pension at that age should be noted. These may include a ban on the termination of employment, amending the conditions of work, remuneration or dismissal notice, 66 as well as a second type of restriction in the case of any economic difficulties of the employer. ${ }^{67}$ Employees aged 45 and over who are interested in professional development, after registering with the labour service, may participate in trainings organized by the public employment services, ${ }^{68}$

61 Art. 104b of the Act on Promotion of Employment, T. Wrocławska, Komentarz do art. 104b, [in:] Z. Góral (ed.), Ustawa o promocji zatrudnienia i instytucjach rynku pracy. Komentarz, p. 1027.

62 Article $9 \mathrm{~b}$ of the Law of 13 July 2006 on the protection of employees' claims in the event of the insolvency of the employer, consolidated text Journal of Laws 2016, item 1256 as amended Cf. M. Włodarczyk, M. Paluszkiewicz, Formy prawne..., p. 46.

63 Article 73 (1) (2) of the Act on promotion of employment, more details: Z. Góral, Komentarz do art. 73, [in:] Góral Z. (ed.), Ustawa o promocji zatrudnienia i instytucjach rynku pracy. Komentarz, p. 833.

64 Article 72 (3) of the Act on promotion of employment, more details: Z. Góral, Komentarz do art. 72, [in:] Z. Góral (ed.), Ustawa o promocji zatrudnienia i instytucjach rynku pracy. Komentarz, pp. 826-827.

65 Article 92 § 4-5 of the Labour Code Cf. M. Włodarczyk, M. Paluszkiewicz, Formy prawne..., p. 46; M. Paluszkiewicz, Wyrównywanie..., p. 12.

66 Article 39 of the Act of 26 June 1974 - Labour Code, consolidated text Journal of Laws 2016, item 1666 as amended, hereinafter: L.C. See M. Paluszkiewicz, Wyrównywanie..., pp. $12-13$ and the literature cited therein.

67 Cf. Article 5 (5) (1) of the Act of 13 March 2003 on special rules for terminating employment relationships for reasons not related to employees, consolidated text Journal of Laws 2016, item 1474.

68 Article 43 (3) in conjunction with Articles 40 and 41 (4-7) of the Act on Promotion of Employment, more details: M. Paluszkiewicz, Wyrównywanie..., p. 14. 
obtain a loan to finance training costs, ${ }^{69}$ or get a grant for postgraduate studies. ${ }^{70}$ In turn, opportunities for financial support for employers are provided by the $\mathrm{Na}$ tional Training Fund, whose funds are a part of the separate Labour Fund. ${ }^{71}$ NTF funds may be provided for employees' lifelong learning activities within the framework of the priorities for the fund for a given year. ${ }^{72}$ The amount of support depends on the size of the employer. ${ }^{73}$ Every employee, including an older person, who wishes to improve their professional qualifications, is entitled, in certain circumstances, to exemption from work and training leave while retaining the right to remuneration. The employer may, on their own initiative, finance any additional entitlements associated with it, such as the cost of training, travel, accommodation or purchase of textbooks. ${ }^{74}$ Due to the need to adapt the legislation to EU requirements, ${ }^{75}$ Polish anti-discrimination regulation, which is included primarily in the Labour Code ${ }^{76}$ as well as in the Act of December $3^{\text {rd }}, 2010$ on the implementation of certain European Union rules on equal treatment, ${ }^{77}$ differs little from the solutions in force in the studied countries. In particular, the justification for the difference in treatment on the basis of age is the application of the criterion of seniority in determining the conditions of employment and dismissal, remuneration and promotion, and access to training to improve professional qualifications. ${ }^{78}$

At present, the situation of the older people in the labour market is gradually improving. The employment rate for the older people in 2016 was $54.7 \%$, with the EU average at $63.4 \% .{ }^{79}$ In the age group $50-54$, it reached $75 \%$, in the $55-59$ age group

69 Article 43 (3) in conjunction with Article 42 of the Act on Promotion of Employment, M. Paluszkiewicz, Wyrównywanie..., p. 14.

70 Article 43 (3) in conjunction with Article 42a (1-4) of the Act on Promotion of Employment, M. Paluszkiewicz, Wyrównywanie..., p. 15.

71 Articles 69a-69b of the Act on Promotion of Employment. E. Bielak-Jomaa, Komentarz do art. 69a-69b, [in:] Z. Góral (ed.), Ustawa o promocji zatrudnienia i instytucjach rynku pracy. Komentarz, pp. 778-787.

$72 \S 2$ (1) of Regulation of the Minister of Labor and Social Policy of 14 May 2014 on the allocation of funds from the National Training Fund, Journal of Laws, item. 639 as amended In 2017, among others, a priority-support for the lifelong learning of people aged over 45 may be financed from reserve funds (PLN 39318.9 thousand) left at the disposal of the Minister of Labor -https://www.google.pl/url?sa=t\&rct=j\&q=\&esrc=s\& source=web\&cd=1\&ved=0ahUKEwi_gNS3meHUAhWhYZoKHXSfAJoQFggnMAA\&url=h ttps\%3A\%2F\%2Fwww.mpips.gov.pl\%2Fdownload\%2Fgfx\%2Fmpips\%2Fpl\%2Fdefau Itopisy\%2F10058\%2F1\%2F1\%2Fpriorytety\%2520KFS\%25202017.pdf\&usg=AFQjCNG-Pii_NoFVjU1iN50w94CmA_fiyg\&cad=rja, (accessed: 28.06.2017).

73 Types of costs are enumerated in Article 69a (2) of the act on promotion.

74 Cf. Articles $103^{1-103^{6}}$ of the L.C.

75 In particular, the Directive 2000/78/EC.

76 Articles $18^{3 \mathrm{a}}-18^{3 \mathrm{e}}$ of the L.C.

77 Consolidated text Journal of Laws 2016, item 1219.

78 Article $18^{3 \mathrm{~b}} \S 2$ (4) of the L.C.

79 http://ec.europa.eu/eurostat/web/products-datasets/-/lfsa_ergan, (accessed: 27.06.2017). 
$-61.7 \%$, and in the $60-64$ age group - only $17.7 \% .80$ This is partly due to a retirement age lower than the statutory retirement age. ${ }^{81}$ The employment rate is an indicator of the degree of labour resources use. Indirectly, it is a measure of the welfare state, since a small number of employees can indicate the broad sphere of distribution of national income, among others, in the form of social benefits. ${ }^{82}$

With regard to the unemployment rate of older people, in 2016 it amounted to $4.5 \% .83$ In the age group $50-54$, this rate reached $4.7 \%$, in the group $55-59-4.6 \%$, and in the group $60-64-4.0 \% .^{84}$ This leads to the conclusion that with a low unemployment rate in the 60-64 age group and at the same time a low employment rate, a large proportion of these people, despite not reaching retirement age receive social benefits. 85

Unemployment among older people in Poland, as in the studied countries, is mainly structural. This is also true of long-term unemployment - according to LFS, the average time taken to acquire a job by the unemployed over the age of 50 was 17 months in $2015 .{ }^{86}$ Among the unemployed over 50 years of age, the largest group were those without work for over 24 months (33.4\%), while those out of work for between 12-24 months accounted for $17.1 \% .{ }^{87}$ This shows that about half of the unemployed in the indicated age group are affected by long-term unemployment. This also affects the low rate for older unemployed people eligible for unemployment benefits. 88

The main cause of the situation outlined above is the unsatisfactory health status of the older people, the uncertain situation in the labour market and the lack of knowledge and skills in using modern technology. ${ }^{89}$ Sometimes the barrier to taking up or continuing employment by the older people is also the attitude of the employers themselves, who, despite knowing the advantages of hiring an older employee,

80 http://ec.europa.eu/eurostat/web/products-datasets/-/lfsa_ergan, (accessed:27.06.2017).

81 Approx. 59.5 years for women and 60.1 years for men. More details: B. Urbaniak, Sytuacja zawodowa kobiet i mężczyzn w wieku 45/50+, [in:] E. Kryńska, J. Krzyszkowski, B. Urbaniak, J. Wiktorowicz (eds.), Diagnoza obecnej sytuacji kobiet i mężczyzn 50+ na rynku pracy w Polsce. Raport końcowy, Łódź 2013, p. 71.

82 M. Kabaj, Strategie..., p. 43.

83 http://ec.europa.eu/eurostat/web/products-datasets/-/Ifsa_urgaed, (accessed: 27.06.2017).

84 http://appsso.eurostat.ec.europa.eu/nui/submitViewTableAction.do, (accessed: 27.06.2017).

85 More details: U. Sztanderska, Przyczyny wczesnej dezaktywizacji zawodowej i emerytalnej osób ubezpieczonych w ZUS, [in:] Dezaktywizacja osób w wieku okołoemerytalnym. Raport z badań, Warszawa 2008, p. 18.

86 Główny Urząd Statystyczny, Osoby powyżej 50. roku życia na rynku pracy w 2015 r., Warszawa-Bydgoszcz 2017, p. 55. There is no Eurostat data in this regard.

87 Główny Urząd Statystyczny, Osoby powyżej 50. roku życia..., p. 57.

88 J. Wiktorowicz, Streszczenie, [in:] E. Kryńska, J. Krzyszkowski, B. Urbaniak, J. Wiktorowicz (eds.), Diagnoza obecnej sytuacji kobiet i mężczyzn 50+ na rynku pracy w Polsce..., p. 12. 
perceive them through the prism of faults. ${ }^{90}$ These drawbacks are, in particular: a lower level of education, lack of ability to use modern technology effectively, aversion to training, lack of creativity, elevated attitudes resulting from the previous political system, poor health, lower productivity. ${ }^{91}$ The latter issue, along with remuneration systems that link salaries to the length of service, is an important factor in encouraging employers to replace older workers with younger ones. ${ }^{92}$ These issues also make employers more reluctant to hire older unemployed people, and if they do, the basis for employment is then the unsustainable flexible form of employment. ${ }^{93}$

The dominant form of employment of already employed older people in Poland is the indefinite employment contract, followed by the fixed-term employment contract and self-employment. ${ }^{94}$ Fixed-term employment is more likely to occur in the public sector and usually among larger employers. ${ }^{95}$ Among the flexible forms of employment, the most popular are fixed-term employment contracts (about 5-6\%), and to a much lesser extent civil-law contracts. ${ }^{96}$ The most common form of employment for older workers is full-time work ${ }^{97}$, only one in ten people over the age of 45 work part-time ${ }^{98}$. The main reason for part-time employment is the lack of full-time job offers, less often, health problems or the restructuring of the workplace. ${ }^{99}$

Research confirms that Polish employers discriminate against candidates for employment based on age. This is most often in the ways they formulate job offers as well as the course of the interview itself. 100 Moreover, employers themselves, mainly from the private sector (11\%), admit that, for a variety of reasons, they prefer to employ younger workers. 101

90 A set of beliefs, prejudices and stereotypes based on the biological diversity of people connected to the aging process, which relate to the competencies and needs of people according to their chronological age, is defined in the literarture as ageism - more details: P. Szukalski, Zagrożenia dla aktywności osób starszych na rynku pracy w Polsce, [in:] P. Szukalski, B. Szatur-Jaworska (eds.), Aktywne starzenie się - przeciwdziałanie barierom, Łódź 2014, p. 23 and the literature cited therein.

91 U. Sztanderska, Przyczyny..., pp. 24-25; I. Kołodziejczyk-Olczak, Zarzqdzanie wiekiem a polityka wspierania starszych pracowników. Doświadczenia polskie na tle innych krajów, "Studia Demograficzne" 2014, vol. 2, p. 52 and the references cited therein; E. Kryńska, I. Kukulak-Dolata, I. Poliwczak, K. Wojtaszczyk, Perspektywa instytucji rynku pracy, [in:] E. Kryńska, J. Krzyszkowski, B. Urbaniak, J. Wiktorowicz (eds.), Diagnoza obecnej sytuacji kobiet i mężczyzn 50+ na rynku pracy w Polsce..., p. 196.

92 U. Sztanderska, Przyczyny..., p. 25.

93 Ibidem.

94 More details: B. Urbaniak, Sytuacja zawodowa..., pp. 66-67.

95 More details: B. Urbaniak, Podstawowe charakterystyki..., pp. 109-110.

96 More details: ibidem, p. 110.

97 Approx. 89\%. More details: ibidem, p. 113.

98 H. Sobocka-Szczapa (ed.), I. Poliwczak, Diagnoza..., p. 72.

99 More details: B. Urbaniak, Podstawowe charakterystyki..., p. 116.

100 More details: P. Szukalski, Zagrożenia dla aktywności..., pp. 14-15; E. Kryńska, I. Kukulak-Dolata, I. Poliwczak, K. Wojtaszczyk, Perspektywa instytucji rynku pracy..., p. 196.

101 J. Wiktorowicz, Streszczenie..., p. 20. 
The main factors taken into consideration by Polish employers in organizing the work of older employees are his/her qualifications and professional experience. The conditions of employment are not generally adjusted to the age-related psychophysical ability to perform work. ${ }^{102}$ Every fourth employer employs men and women aged $45 / 50+$ on Saturdays, Sundays and public holidays, almost half assigns them tasks outside their regular worokplace, and every sixth entrusts them to work overtime, every tenth at night. ${ }^{103}$ Employers also make little effort to maintain the health of employees, such as the financing of additional health insurance, preventive vaccination, or physical activity during their free time. ${ }^{104}$ Research shows that Polish employers rarely apply age management policies at workplaces - they do not seperately assess the competencies of older workers nor do they create career development plans for them. The actions taken, depending on the size of the employer, are mainly limited to moving older workers to other positions or to using their work experience in mentoring. 105

The wage structure in Poland mostly increases among workers until the age of 34 , and then stabilizes with little change until retirement age. In the years $2004-$ 2010 the age-related salary range decreased from $111 \%$ to less than $83 \%$, which is due to the increase in both the average and the minimum wage. ${ }^{106}$ Employers, especially in the public sector, form remuneration systems that contain age-related components, such as, in particular, a seniority supplement, thereby promoting employee loyalty, which, unfortunately, does not always affect the efficiency of the work performed. ${ }^{107}$

By refering to the diagnosis of the situation of older unemployed people in Poland, the most popular as the offered basis of employment is the fixed-term employment contract, especially in the public sector. ${ }^{108}$ Part-time work is also more commonly used with respect to newly employed older workers than when modifying employment conditions. ${ }^{109}$ On the other hand, employment through temporary employment agencies is far less frequent. ${ }^{110}$ In Poland, the forms of subsidized employment play a relatively minor role in the employment of the older people (4.6\% in the public sector and $0.9 \%$ in the private sector). ${ }^{111}$ According to research, about $16 \%$ of employers

102 More details: B. Urbaniak, Podstawowe charakterystyki..., p. 119.

103 E. Kryńska, J. Krzyszkowski, B. Urbaniak, Wnioski generalne, [in:] E. Kryńska, J. Krzyszkowski, B. Urbaniak, J. Wiktorowicz (eds.), Diagnoza obecnej sytuacji kobiet i mężczyzn 50+ na rynku pracy w Polsce..., p. 302.

104 Approx. $14 \%$ of the surveyed employers, among which entities employing more than 250 employees dominated. More details: B. Urbaniak, Podstawowe charakterystyki..., p. 119.

105 I. Kołodziejczyk-Olczak, Zarzq̨dzanie wiekiem..., p. 52 and the references cited therein.

106 W. S. Zgliczyński, Wynagrodzenia w Polsce, "Infos" 2013, no. 22 (159), p. 3.

107 More details: B. Urbaniak, Podstawowe charakterystyki..., pp. 158-159.

108 More details: ibidem, p. 129.

109 More details: ibidem, p. 130.

110 In principle, by every 9-10 average and larger employer. More details: ibidem, pp. 111 and 129.

111 More details: ibidem p. 111. 
benefitted from supported employment of older workers. Most often, it was subsidized employment, mainly in small and medium-sized companies. ${ }^{112}$ As far as public work is concerned, it is most often used by public employment services to address the effects of natural disasters, particularly floods, and, when working with social assistance centers, where they are used as a means to prevent social exclusion of the unemployed older people. ${ }^{113}$ As far as self-employment is concerned, almost half were over 45 years of age. ${ }^{114}$ The incentive for the unemployed to take this career path may be their refusal to accept the employment conditions offered by employers, as well as the discriminatory practices encountered in the search for employment. ${ }^{115}$ Promoting self-employment is highly effective in combating unemployment - employability is close to $100 \%$ in one to two years. The results of the survey indicate, however, that it does not occur on a large scale, mainly due to the financial constraints faced by the public employment services. ${ }^{116}$ As regards training of the unemployed, including the older people, it is organized by public employment services in cooperation with training institutions. ${ }^{117}$ If carried out by external entities, then an unemployed person, including an older one, may receive financial support from the Labour Fund. ${ }^{118}$ Actions undertaken by the public employment services towards unemployed persons are individualized, but, according to research, those programs aimed at unemployed older persons were not commonly used. This was mostly due to the conviction that the legislator had guaranteed a wide range of instruments for the activation of the indicated unemployed group, so there was no longer any need for additional initiatives. Procedural difficulties were reported to be another important cause of the lack of such measures, especially the time spent on the preparation of funding proposals, as well as the difficulty in the practical implementation of the timely allocation of the annual budget grant. ${ }^{119}$ It was also pointed out that the legislator included other unemployed groups in the category of persons in a special, sometimes more needy, situation on the labour market. ${ }^{120}$ The most frequently undertaken actions of the public employment services towards the older unemployed were subsidizing employment, public works, trainings and internships. ${ }^{121}$

112 In principle, by every 9-10 average and larger employer. More details: ibidem, p. 129.

113 E. Kryńska, I. Kukulak-Dolata, I. Poliwczak, K. Wojtaszczyk, Wsparcie oferowane przez instytucje rynku pracy, [in:] E. Kryńska, J. Krzyszkowski, B. Urbaniak, J. Wiktorowicz (eds.), Diagnoza obecnej sytuacji kobiet i mężczyzn 50+ na rynku pracy w Polsce..., p. 256.

114 More details: B. Urbaniak, Sytuacja zawodowa..., p. 72.

115 H. Sobocka-Szczapa, I. Poliwczak, Diagnoza..., p. 71.

116 E. Kryńska, I. Kukulak-Dolata, I. Poliwczak, K. Wojtaszczyk, Wsparcie oferowane przez instytucje rynku pracy, pp. 256-257.

117 Articles 40-41 of the Act on promotion of employment.

118 Articles 42-42a of the Act on promotion of employment.

119 E. Kryńska, I. Kukulak-Dolata, I. Poliwczak, K. Wojtaszczyk, Wsparcie oferowane przez instytucje rynku pracy, p. 255.

120 Ibidem, p. 256.

121 Ibidem. 


\section{Conclusions}

1. Looking for model solutions to counteract older people's unemployment, attention should be paid to the different ways the employment relationship in Poland and the countries surveyed is shaped. This influences the methods of creating legal solutions as well as their implementation. The legal solutions proposed by the legislator, which are inherently general and abstract, are unified and often poorly adapted to the needs of labour market participants. In the case of Poland, it is also partly related to the relatively short time that this country has functioned in changed political conditions. It seems that the long period of state domination in regulating social life and the effects of the socio-economic transformation, especially the associated high unemployment, have affected the, weak, development of collective labour law. A similar situation, mutatis mutandis, is based on an analysis of the determinants of labour law development in Hungary and also in the former German Democratic Republic. This contrasts with the situation in Belgium and Denmark, where the main initiative in shaping the employment relationship belongs to the social partners. Depending on their needs, they create solutions to support the employment of older workers. Examples of this type of approach include, in particular; creative dialogues between older workers and their managers in Denmark, Belgian companies' employment plans for older workers, and a number of industry-wide collective agreements on the prolongation of the working life of older workers in Germany.

All this leads to the conclusion that regulating employment relations mainly through generally applicable laws results in the lower flexibility of the adopted solutions, which, in turn, results in their efficiency. This is also reflected in the different employment rates for the older workers in the surveyed countries. In conclusion, the Polish legislator should create favorable conditions for the development of social dialogue and more effectively encourage social partners to develop solutions tailored to their diversified needs in the form of an autonomous labour law. During the transitional period, workplace regulations can be used as a tool for the development of personalized solutions for the employment of the older workers. ${ }^{1}$

2. The analysis of legal arrangements in other countries in relation to the older workers suggests that their needs in the working environment, associated with the natural aging process, are similar. Taking these needs into consideration is a prerequisite for effectively supporting their employment.

The need for broadly understood health protection is at the forefront, both in the workplace and outside. Looking for model solutions, the possibility of creating a preventive health protection system for older workers based on a comparative legal analysis should, in particular, be taken into account.

1 Cf. Articles $104-104^{3}$ in conjunction with Article 9 of the L.C. 
This could include measures to prevent the occurrence, mainly in the work environment, of factors accelerating the degradation of the body and the aging process. This would primarily be to raise awareness among employers about the specific needs of employees related to the age and on the ability to eliminate health risks through the proper organization of work. ${ }^{2}$

Going forward, one could also propose an increase in the frequency of periodic medical examinations for employees. At present, the date of the next visit is determined by the physician who takes preventive care of the employees, ${ }^{3}$ in practice, this means that older workers are unlikely to undergo additional health checks. Frequent checks of this type may also be perceived by employees themselves as a factor destabilizing their position within the employment relationship. In view of the above, it would be useful to consider introducing appropriate legislation to intensify preventive medical examinations for older workers. As the costs of medical examinations are now borne by employers, ${ }^{4}$ it would be necessary to provide support from public funds, possibly financing them entirely from this source, as is the case in Belgium or Denmark. Another issue is the age for the employee to undergo that type of examination. Medical specialists point out that a decrease in exercise capacity and physical fitness, as well as certain psychophysical abilities, such as perceptiveness, speed of reaction, sensory abilities, are observed after reaching the age of $45 .{ }^{5}$ It seems that the nature of the work performed, in particular its detrimental effect on health should be taken into account here.

Determining the risk to the health of the employee should be reflected in work organization, such as, in particular, exclusion of older employees from night shift, overtime, work requiring a lot of physical effort, or work likely to lead to repetitive strain injuries, etc. Solutions based on similar assumptions apply if employees show signs of the development of an occupational disease. ${ }^{6}$ The proposed measures would include increasing the involvement of the occupational health service, which would individualy assess the needs of older workers. A health assessment could result in the employee being required to undergo vocational rehabilitation or professional

2 Cf. M. Paluszkiewicz, Wyrównywanie..., p.16.

3 Based on methodological guidance on performing preventive examinations of employees, shown in Annex 1 to the Regulation of the Minister of Health and Welfare of 30 May 1996 on medical examinations of employees, the scope of employee preventive health care, and medical diagnoses issued for the purposes stated in the Labour Code, consolidated text Journal of Laws 2016, item 2067.

4 Article 12 (2) (6) of occupational medicine service act of June 27, 1991, consolidated text. Journal Of Laws 2014, item 1184 as amended, Article $229 \S 3$ of the L.C.

5 J. Bugajska, Pracownicy starsi-możliwości i uwarunkowania fizyczne, Warszawa 2007, p. 5.

6 Cf. Article 230 of L.C. 
retraining. It is also worth considering to provide employers with financial support in the form of reimbursement of the costs of any special needs assessment by the occupational health service and, in the case of employees, more frequent use of social security benefits, such as compensatory allowance $^{7}$ or a retraining benefit. ${ }^{8}$ In less serious cases, the assessment may lead to smaller-scale actions, both organizational and financial. Using the Danish example, this could mean creating a plan to retain an older employee or a plan to support the return to work of an older employee who is no longer able to do their original job due to health issues. As regards the organization of work with an older employee, the possibility of a reduced work schedule is worth considering. Due to the associated lower salary, however, a 'top up' scheme would need to be considered. A solutions in this regard, could come from the partial pension possible under the Polish legal system (until October $\left.1^{\text {st }}, 2017\right)$, which can be combined with employment, amounting to $50 \%$ of the old-age pension. However, the disadvantages of this solution include the reduction of the pension capital, resulting in the potential reduction of the retirement pension after reaching the statutory retirement age. ${ }^{9}$ Looking for other solutions in this respect, it would be appropriate to supplement public remuneration, for example from the Labour Fund. This solution is currently used in the case of a reduction in employees' working hours due to the economic difficulties of the employer. ${ }^{10}$ In the countries surveyed, the older employees also have the opportunity to take additional holiday leave. Also worth noting is the Belgian solution of offering a financial premium to employers who move older employees from night to daytime shift.

In cases where complete elimination of detrimental factors is not feasible, even with appropriate preventive measures, a system should be introduced to support the retraining of workers performing work likely to lead to health issues. Long-term performance of this type of work causes the body to age faster. Support for this change of role needs to be put in place as early as possible, since employees carrying out this kind of work have reached a fixed length of service. Actions taken by the Polish legislator, so far consisting of the gradual phasing out of pensions at a lower age for workers performing work in difficult health conditions should be acknowledged as insufficient. Without assistance in the process of professional retraining, these people will be exposed to a high risk of unemployment.

7 Articles 23-25 of the Act of 25 June 1999 on cash benefits from social security in case of sickness and maternity, consolidated text Journal of Laws 2016, item 372.

8 Article 60 of the Act of 17 December 1998 on pensions from the Social Insurance Fund, consolidated text Journal of Laws 2016, item 887 as amended.

9 Article 26b of the Act of 17 December 1998 on pensions from the Social Insurance Fund, consolidated text Journal of Laws 2016, item 887 as amended.

10 Article 5 (2) of the law of 11 October 2013 on special solutions related to the protection of jobs, consolidated text Journal of Laws 2017, item 842. 
Another factor hindering the retention of older workers is their level of professional qualifications, which is generally lower than for younger people. ${ }^{11}$ It seems that the low proportion of older workers participating in lifelong learning processes results, among others, from the insufficient amount of public funds allocated to this type of activity. For example, in 2017, only $1.7 \%$ of the Labour Fund resources were allocated to the National Training Fund, and the lifelong learning of employees over 45 was to be one of the additional purposes of this fund, which, in turn amounted to less than $0.35 \%$ of Labour Fund resources. ${ }^{12}$ At this point, an important question arises of whether it is possible to make appropriate transfers under the Labour Fund in order to increase the resources allocated to training, or whether it would be more rational to create a separate fund or program for that purpose, based on the experience of countries such as Denmark or Germany. Another issue related to the lifelong learning of older workers is the type of qualification demanded in the labour market. It appears that social partners should be included in the creation of a list of deficit and surplus professions. ${ }^{13}$ Experience gained from observing this institution in other countries also justifies calling for their commitment to the development of types of education programs, their form (in-work should dominate), and their duration. It is also worth supporting employers in assessing which qualifications their employees need. In this regard, noteworthy are the personal consulting programs carried out in Germany. Lastly, with regard to employers' concerns about the short-term viability of updating the qualifications of older employees, it is important to highlight that they have the right, in the light of the regulations in force, to oblige employees to remain in employment for a limited period of time after completion of the qualification process. ${ }^{14}$

Another obstacle hampering the active participation of older employees is the low flexibility of employment. Due to the low average Polish remuneration, it is difficult to see an effective solution in part-time employment. It is worth, however, taking advantage of the experience of the surveyed countries in which it is possible to supplement the remuneration of older employees working part-time from public funds. It should also be noted that

11 Program of the Council of Ministers, Solidarność pokoleń. Działania dla zwiększenia aktywności zawodowej osób w wieku 50+, Warszawa 2008, p. 10; More details: B. Urbaniak, Sytuacja zawodowa..., pp. 68-71.

12 Own calculations based on data provided in: Detailed information on expenditures of the Labour Fund, http://www.mpips.gov.pl/praca/Fundusz-pracy/szczegolowe-information-of-the-development-of-the-financial-payments-of-2006-20-20-a-plan -ne-2015-r /, (accessed: 30.06.2017).

13 It is run by the public employment services - Article 8 (1) (3) of the Act on promotion of employment.

Article $103^{4} \S 3$ of the L.C. 
in most of the surveyed countries, temporary employment is not widespread as a form of employment for older people. As regards flexibile employment as one of the important elements in counteracting older people's unemployment, there is a reflection of a general nature to be made. Based on the Danish experience in the flexicurity model, this flexibility does not have to be, and for older workers it should not be, based on flexible forms of employment, but on the flexible working methods developed jointly by the social partners, preferably at the lowest level of collective bargaining.

The barriers to retaining the older workers may be the perceived associated higher costs. However, the average salary level in Poland does not vary greatly when it comes to age. Moreover, a growing number of employers treat knowledge and the ability to apply it, as the primary salary-affecting factor. Due to the lower level of education of the older workers and less frequent participation in the process of professional qualification, this may lead to their salaries in fact being lower. ${ }^{15}$

It is worth emphasising that the employer, besides offering a salary, is also obliged to pay various types of guaranteed payments, among them sick pay. Its applicability for older workers is, however, shorter. It is worth noting that this type of instrument was not present in any of the studied countries. The proposed solution would have to be modified because a direct reference to the age category can preserve the stereotype that older workers are more susceptible to illnesses and physical ailments than younger ones. In this respect, the Danish solution could be used as a source of inspiration - reducing the employer's burden when hiring an employee who is at higher risk of absenteeism due to health-related problems.

Another issue related to counteracting unemployment among the older workers is the way to ensure the protection of employment stability. Analysis of the legislation of selected countries allows for the separation of three degrees of protection. The weakest protection is provided in Denmark. It consists of the greater freedom of the employer to terminate the employment relationship, short notice periods and low severance pay. Here, the basic requirement for re-employment is to have current professional qualifications. However, as the majority of older people lack them and are unwilling to acquire them, they have a broad access to generous social security benefits. Limiting the entitlement to social benefits increases the risk of long-term unemployment. Another, medium degree protection of the employment stability of the older workers was adopted in Germany and Belgium. In both countries, termination periods are relatively long, which gives the older workers more time to look for a new job. In Germany, it is also necessary to justify a dismissal - one of the factors that the employer must consider when deciding to lay someone off is age. At the same time, severance pay is

15 More details: B. Urbaniak, Podstawowe charakterystyki..., p. 159. 
linked to the remuneration for notice period, which may be an argument for retaining older employees. The third model is represented by Hungary, in which, as in Poland, special protection is given to the sustainability of pre-retirement employment. At the same time, periods of notice, dependent on seniority, are relatively short. Payments related to remuneration for notice period do not constitute a deterrent in dismissal for the employer.

Undoubtedly, the protection of pre-retirement age workers is a legal instrument that stabilizes their employment. At the same time, it is a significant hindrance to the hiring of older unemployed people, especially on the basis of an indefinite-term contract. If the ban on the dismissal of preretirement workers is to be abolished, it would seem to be acceptable to introduce longer periods of notice of termination of employment, based on length of service. Employers in good financial condition could terminate the contract provided they pay severance for the notice period. If this pre-retirement protection remains, it is possible to consider linking the use of instruments that support the employer financially when hiring older workers at the age, justifying pre-retirement protection.

In the case of so-called group redundancies, it should, inspired by Belgian patterns, include the need to ensure that employees chosen for dismissal reflect the employment structure of the dismissing employer. This could help to eliminate any discriminatory behavior when selecting employees for dismissal. In the case of such redundancies, it is necessary to commence, as early as possible, the implementation of a program supporting immediate re-employment, especially for those older workers at risk of long-term unemployment. For this purpose, the Polish monitored dismissal may be adopted, 16 based on similar assumptions to those in Belgian outplacement.

Stereotypes also play a role in the retention of the older employees, often linked to their, more mature, age (ageism ${ }^{17}$ ), as previously mentioned. According to the analysis, these stereotypes are most often the basis for undertaking discriminatory behavior in relation to employment. Looking for instruments to prevent age discrimination, it does not seem to be justified to intensify administrative sanctions against violations of the principle of equal treatment in employment. It is more important to organize information campaigns on the value of employing older workers (the silver economy ${ }^{18}$ ) as well as their needs in the process of performing work. From

16 Article 70 of the Act on Promotion of Employment, more details: E. Bielak-Jomaa, Komentarz do art. 70, [in:] Z. Góral (ed.) Ustawa o promocji zatrudnienia i instytucjach rynku pracy. Komentarz, pp. 788-795.

17 On this topic: P. Szukalski, Ageizm na polskim rynku pracy, [in:] R. Horodeński, C. Sadowska-Snarska (eds.), Gospodarowanie zasobami pracy na poczq̨tku XXI wieku. Aspekty makroekonomiczne i regionalne, Warszawa-Białystok 2009, pp. 154-167.

18 More details: P. Szukalski, Trzy kolory: srebrny. Co to takiego silver economy?, "Polityka Społeczna" 2012, no. 5-6, pp. 6-10. 
the point of view of combating discriminatory behavior, it is also important for the legislature to abandon constructing legal remedies with direct reference to the age of the employee. This is due to the rarely justified attribution of certain characteristics to the older employee as a whole, cementing their unfavorable image on the labour market. Legal remedies should be constructed taking into account the specific barriers that prevent employment or reintegration, to which age in itself does not belong,

3. The analysis of legal solutions in other countries has shown the typical obstacles encountered by unemployed older people in gaining employment.

As a major obstacle, the high costs of hiring unemployed older people are indicated. In order to eliminate this in the examined countries, including Poland, instruments are provided to support those employers who take on unemployed older people. These allow partial reimbursement of the cost of remuneration, often including social security contributions. The use of this type of assistance is often linked to the retention of the said older member of staff for a certain period of time after the end of the subsidy. Bearing in mind the disadvantages associated with the use of such instruments - in the form of high financial expenditure, moderate efficiency, stigmatization of the participants and the occurrence of deadweight and substitution effects - some modification of their construction should be proposed. In the case of the necessity of using this type of measure, it is desirable first to consider abandoning age as a factor. It would then be necessary to tailor individual support to specific obstacles to employment, such as inadequate professional qualifications, inadequate performance, physical impairment or lower productivity. In such an approach, the employer would not be compensated for part of the cost of the employee's remuneration, but instead receive support enabling the, at least partial, rectification of the cause that disadvantaged the person on the labour market, for example through participation in in-work training or appropriate organization of the process of work or workplace. ${ }^{19}$ As regards the high costs of employing older workers as barriers to job creation, consideration should also be given to the possibility of introducing some modifications to the mechanism for calculating the minimum wage. ${ }^{20}$ An interesting solution based on the experiences of Hungary and Germany could be to make it more flexible, based on the level of education or accumulated professional experience. It seems, however, that the most appropriate approach from the point of view of the interests that deserve protection, would be introducing such an instrument through collective (industry-wide) agreements.

19 Cf. M. Paluszkiewicz, Wyrównywanie..., p. 16.

20 Act of 10 October, 2002 on the minimum remuneration for work, consolidated text Journal of Laws 2017, item 847. 
Employment costs are also reduced by supply-driven instruments. They are particularly important when older workers are paid less than the reservation wage. In Poland this type of instrument is an activation allowance. ${ }^{21}$ Experience in Belgium and Germany leads to the the possibility of prolonging and increase of the pay period, especially for older workers with long work experience. Such modifications could provide real support for the employment of an older employee, and reducing the time it takes to find a better paid job. Another supply-oriented instrument is the retirement bonus. In Belgium, this was granted in conjunction with relinquishing any early retirement option, and is still granted on similar principles in Denmark. The idea of a pension bonus also emerged in Poland due to the reduction of the statutory retirement age from October 1st, 2017 and the need to prolong occupational activity for demographic reasons. According to the plans (which have not yet taken particular shape) a person at retirement age would receive a bonus for postponing their retirement - but for not more than four years - then a special bonus of up to 20,000 PLN would be paid. ${ }^{22}$ Following the example of Belgium, it can be stated that an instrument of this type requires differentiation. This is because a financial incentive does not affect everyone equally. For example, the Belgian experience shows that women are more likely to benefit from this bonus, mainly due to their longer average life expectancy as well as those with relatively low earnings during the period of professional activity.

For older persons, a long period without work is conducive to a loss of performance-related abilities. Public work is often used as a preventative measure in these types of situations, as evidenced by research conducted in the selected countries. The experience gathered leads to the following conclusions. Public work schemes do carry out their basic objective of increasing the chances of unemployed persons in risk groups in the labour market gaining employment, despite their being no formally confirmed acquisition of professional qualifications. In general, the longer your participation in public work programs, the lesser are your chances of accessing unsubsidized employment. This instrument has a strong lock-in effect, crowding out and substitution effect. People who take part in such schemes, usually receive much lower earnings than in the so-called open labour market, which fosters the formation of the so-called working poor. The organization of public works also entails significant financial expenditures, leading to it being limited to a narrow recipient group, which in turn leads to their stigmatization. The positive aspects of this instrument are the short-term mitigation of the effects of unemployment, and the ability to assess readiness to work. In the case of the need for professional activation of long-term

21 Article 48 of the Act on promotion of employment.

22 http://www.money.pl/gospodarka/wiadomosci/artykul/obnizenie-wieku-emerytalnego-morawiecki,174,0,2278574.html, (accessed: 30.06.2017). 
unemployed persons or those distant from the labour market, actions may be outsourced by public employment services externally, especially to employment agencies. ${ }^{23}$ The functioning of this instrument in Germany provides some conclusions in this respect. The effects of the activation measures were unsatisfactory - the effectiveness in taking up employment was moderate, there were significant difficulties in organizing the training and there was a strong deadweight effect.

In order to encourage employers to hire out-of-work older persons, flexible forms of employment may also be used. In Germany, a special regulation has been enacted to make it possible to employ an unemployed person for a maximum period of 5 years on the basis of fixed-term contract. In Hungary, there are no specific solutions addressed to the older people - a fixed-term employment contract of up to 5 years can be concluded with each employee. The solution in force in Poland for the maximum duration of a fixed-term contract, which is 33 months, should be considered more attractive for businesses. However, taking into account the protection of the employment stability of pre-retirement workers, it is unlikely that employers will offer an employment contract for the maximum period of time. In the case of agreeing fixedterm employment contracts for a shorter period of time, there is a mechanism permitting a maximum of three such contracts between the parties. A fourth contract of employment for a fixed term or contract of employment for a period exceeding 33 months in effect becomes an indefinite-term contract. ${ }^{24}$ Self-employment can also be considered a flexible form of employment. Such a form of vocational activation of the older people is not, however, widespread in the studied countries. While older people have more life experience, not only professional, self-employment requires a much stronger financial and organizational commitment and entails greater economic and legal risks than waged employment. It should also be noted that financial support of a non-reimbursability nature for this type of activity has a limited time frame. The actual impact of this instrument on permanent vocational activation should therefore be measured only after this expires. The above considerations militate in favour of addressing this type of instrument to counter unemployment to persons of other age categories.

Another obstacle to taking on unemployed older persons is the lack of relevant qualifications demanded by the labour market. The training used to overcome this obstacle has a major flaw, that is the so-called lockin effect. This is particularly true for long-term training programs that increase the length of time a person is unemployed. In turn, the disadvantage

23 Articles $66 \mathrm{~d}-66 \mathrm{i}$ of the Act on promotion of employment. More details: M. Paluszkiewicz, Agencje zatrudnienia po nowelizacji ustawy o promocji zatrudnienia i instytucjach rynku pracy, "Praca i Zabezpieczenie Społeczne" 2014, no. 6, pp. 12-13. 
of short-term training is its low impact on taking permanent employment. On the basis of the experience of OECD countries, very significant rules have been formulated for the construction of training programs for the unemployed. The key issue is the proper selection of participants - only persons most in need of updating or acquiring professional qualifications should participate in such programs. Another issue is scale, taking into account the demand for specific professions on local labour markets. An increase in the number of persons with specific qualifications on the market may also contribute to a reduction in the remuneration for their work. The last concerns the form of training. If they contain practical elements in addition to theoretical knowledge, cooperation with local employers should be established in order to ensure their satisfactory execution ${ }^{25}$.

Identifying and removing these barriers is primarily the role of public employment services. On the basis of Danish and Hungarian experience in the functioning of such services, it should be stressed that the frequency of meetings with the clients' advisors has a great influence on the effectiveness of the professional activation of the unemployed. Sometimes the prospect of another meeting with a representative of the public employment services in a short period of time, can mobilize the search for employment. Increasing the frequency of these contacts, however, requires, as confirmed by the Hungarian experience, the employment of a sufficient number of staff in the public employment services. Both staffing and financial constraints hinder the implementation of labour market programs.

In the case of those older people who are particularly at risk of long-term unemployment, the starting point for assistance in taking up employment is also significant. A solution aimed at reducing the period of unemployment was applied in Germany, where registration and special support are possible within the three months preceding the end of employment. Although the Polish legislature stopped prioritising the employment of older people through the public employment services, it is worth noting, that monitored dismissal allows for the possibility of early assistance.

Public employment services in the studied countries, as well as in Poland, are able to launch programs addressed at risk groups on the labour market. ${ }^{26}$ These are particularly flexible measures to facilitate the appropriate adaptation of legal instruments to the specific situation of the local labour market, and, therefore, play a significant role in territorial differentiation of unemployment. Lack of experience in the application of these programs

25 M. Paluszkiewicz, Wybrane środki prawne wspierajace bezrobotne osoby starsze w podjęciu zatrudnienia w Niemczech, p. 36 and the literature cited therein.

26 Articles $66 a-66 c$ of the Act on Promotion of Employment. More details: M. Paluszkiewicz, Komentarz do rozdziału 13a i 13b, [in:] Z. Góral (ed.), Ustawa o promocji zatrudnienia i instytucjach rynku pracy, pp. 707-725. 
in Poland appears to be due to the over-standardization of the activities of public employment services. The social nature of the services requires, due to the limitations of organizational and financial resources, certain laid down operational procedures. Habituation to their strict application may, however, causes difficulties in undertaking unconventional and non-standard activities whose application is forced by the contemporary labour market, among others, in relation to the older people. Examples of non-standard actions taken in favour of older persons are based on analysis of solutions in other countries. Support in finding employment can also be provided on the principle of self-help, with the financial participation of the labour administration. The experience gained in the framework of the Danish seniors network was used in Polish conditions under the ESF co-financed project "Wspólnie aktywni - model pracowni aktywizacji osób 45+", implemented by the Municipal Office of Łódź, Marshal Office of Łódź, NSZZ Solidarność Ziemi Łódzkiej and the Danish city of Aarhus. Within its framework, it was possible for the participants of the workshop to gain new skills, to seek employment by contacting employers. The project lasted for 2.5 years and was attended by 120 participants (residents of Lodz province). Of these, 42 were later employed, while the remaining participants acquired professional competence through individual training or computer literacy. 27

Some conclusions also follow the analysis of the legal provisions of the surveyed countries on benefits that mitigate the effects of unemployment. Irrespective of the accepted technique for hedging the risk of unemployment, the right to unemployment benefit is derived from professional activity during the reference period. The duration of unemployment benefits for older people in most of the surveyed countries, as in Poland, 28 is longer since older people need additional time to successfully find a job. Legislators praise the revenue function of unemployment benefit, attaching less importance to its motivational function. This is confirmed by the study, which shows that the long the period of taking the benefit, the less effective the job search. It is also worth stressing that unemployment benefit is the appropriate instrument for mitigating the effects of short-term, rather than long-term, unemployment, ${ }^{29}$ and for these reasons, it is difficult to seriously consider the possibility of adopting the Belgian option. On the other hand, it seems that the length of benefit allowance in Hungary is too restrictive and may necessitate the widespread use of supportive social assistance systems to satisfy the basic necessities of life. With regard to this structural component

27 Wojewódzki Urząd Pracy w Łodzi, Informacja z realizacji Regionalnego Planu Działań na rzecz Zatrudnienia w województwie łódzkim w 2013 r., Łódź 2014, pp. 18-19.

28 Article 73 (1) (2) (c) of the Act on promotion of employment.

29 A phenomenon in this respect is the unlimited unemployment benefit in Belgium which, in terms of legal nature, resembles a bridging benefit until old age benefits are paid. 
of unemployment benefit, it appears that the Polish legislator has adopted a rational solution. For persons whose benefit duration is too short to take up employment, a safety net is provided by social security ${ }^{30}$ similarly to the surveyed countries. In addition to income and subsistence tests, a condition for provision is the active cooperation with the relevant services in order to overcome the difficult life situations that are the effect of unemployment.

In terms of determining the amount of benefit, unlike in Poland, 31 in the studied countries a regulation was adopted justifying the treatment of this benefit as a partial compensation for lost earnings, whose amount is also affected by the family situation. Some legislation also provides for a different solution, which is to grant the unemployed older persons a special supplement in addition to the unemployment benefit. The Polish regulations applicable in that regard, which provide for a fixed amount of allowance irrespective of the level of remuneration received, do not meet the basic standards of social security and are criticized in the literature. ${ }^{32}$ This assessment is not altered by the slight differentiation in the amount of the benefit connected to the length of service. Looking for model solutions, it is worth noting that in some countries there are no negative consequences of taking up a profit-making activity on a small scale on the status of the unemployed and unemployed benefit. Such a solution prevents the unemployed persons from completely losing contact with the labour market.

The policy of limiting access to benefits which eliminate older persons at pre-retirement age totally from unemployment pool, such as, in particular, early retirement or pre-retirement benefits, adopted and consistently implemented in both Poland and the surveyed countries, is also to be welcomed. It is also worth noting that incentives to engage in professional activity also come from the pension systems of the surveyed countries. These include primarily the exemption of periods of unemployment from period demanded to acquire retirement entitlement, as well as the strong dependence of the old-age entitlement on the level of earnings during the period of professional activity. Due to the frequent reforms of the Polish pension system and the resulting uncertainty regarding the rights in statu nascendi, it is difficult to assess whether national pension rights regulations motivate

30 Law of 12 March 2004 on social assistance, consolidated text Journal of Laws 2016, item 930; Act of 13 June 2003 on social employment, consolidated text Journal of Laws 2016, item 1828.

31 The flat-rate amount depends on the length of the insurance period - Article 71 (1) and (3) of the Act on promotion of employment.

32 G. Uścińska, Europejskie standardy zabezpieczenia społecznego a współczesne rozwiqzania polskie, Instytut Pracy i Spraw Socjalnych, Warszawa 2005, p. 575; K. Jaworska, Standardy Międzynarodowej Organizacji Pracy i Rady Europy a polski system zabezpieczenia społecznego na wypadek bezrobocia, "Studia Prawnoustrojowe" 2014, no. 24, p. 167. 
the unemployed to seek employment effectively. The existing rules for determining pension rates are based on individual precautions, however, they allow the inclusion of the period of receiving unemployment benefits to periods determining old-age benefits' amount. ${ }^{33}$ The formula for determining the amount of the pension, based on the amount of accumulated pension capital in relation to average projected further life expectancy, most certainly rewards those persons whose health allows them to delay the moment of professional deactivation. For these reasons, it is essential to create appropriate legal measures to stabilize the employment of the older people and to assist them to return to employment. Only when conditions are created that favor the prolongation of occupational activity, it will be necessary to reflect on the appropriate retirement age. Due to the fact that the aging process is a highly individualized one, a possible solution is to introduce a flexible retirement age. ${ }^{34}$ Under such circumstances, the need to raise the retirement age is more likely to be socially acceptable.

33 Cf. Article (6) (1) in conjunction with Article 25 (1) of the Act on pensions from the Social Insurance Fund.

34 W. Szubert, Ubezpieczenie społeczne. Zarys systemu, Warszawa 1987, p. 105; M. Paluszkiewicz, Wyrównywanie..., p. 16. 



\section{Part II}

\section{Tatiana Wroctawska}

\section{General introductory notes}

Changes in demographic structure and the significant increase in the number of older people necessitate the search for solutions that encourage people to remain in employment for as long as possible. Hence, so called healthy aging, life-long learning and age management have become the priority for countries facing the problem of an ageing society. The issue of extending the professional activity of people at preretirement and retirement age is complex and often requires considerable changes in interlinked areas, starting with pension rights, solutions relating to promoting employment and the improved performance of work by older people through better health care and social assistance. It also means that the processes involved in finding optimal solutions are dynamic and dependent on many factors: social, economic and legal.

The matter of prolonging professional activity of the older person is becoming increasingly apparent in sources from abroad, ${ }^{1}$ as well as in research conducted by international organizations. ${ }^{2}$ Agendas and programmes initiated by European

1 For more see in particular P. Taylor (ed.), Ageing Labour Forces. Promises and Prospects, Cheltenham, UK- Northampton, Massachusetts, 2008, A. Blackham, Extending Working Life for Older Workers, Oxford-Portland, Oregon 2016, S. Bisom-Rapp and Malcolm Sergeant, Lifetime Disadvantage, Discrimination and the Gendered Workforce, Cambridge 2016.

2 For example see: ILO, Decent Work and the 2030 Agenda for Sustainable Development, available at: http://www.ilo.org/global/topics/sdg-2030/lang--en/index.htm, (accessed: September 2017).

WHO, The Global Strategy and Action Plan on Ageing and Health Considered and Adopted by the WHA, Multisectoral Action for a Life Course Approach to Healthy Ageing: 
Union institutions are also noteworthy. ${ }^{3}$ The guidelines contained therein also determine the directions of action across a range of areas at national levels. ${ }^{4}$ Legal regulations adopted recently in Poland which are a response to the objectives established within the EU framework are also important in this respect. ${ }^{5}$ Changes made in legal regulations also mean that the analysed subject matter is highly present in Polish publications. ${ }^{6}$

Draft Global Strategy and Plan of Action on Ageing and Health, Document A69/17, 22 April 2016, available at: http://apps.who.int/gb/ebwha/pdf_files/WHA69/ A69_17-en.pdf, (accessed: September 2017). WHO, World Report on Ageing and Health, Luxemburg: WHO, 2015, available at: http://apps.who.int/iris/bitstream/10665/186463/1/9789240694811_eng.pdf?ua=1 (accessed: 1.06.2017). OECD insights. Debate the Issue: Health Systems are Still not Prepared for an Ageing Population, last modified April 29, 2015, available at: http://oecdinsights.org/2015/04/29/health-systems-are-still-not-prepared-for-an-ageing-population/ (accessed: 1.06.2017), OECD, Ageing and Employment Policies. Working Better With Age, Paris 2015.

3 European Commission, Communication from the Commission, Europe 2020, A Strategy for Smart, Sustainable and Inclusive Growth, Brussels, 3.3.2010 com(2010) 2020, available at: http://ec.europa.eu/eu2020/pdf/complet\%20en\%20barroso\%20\%20\%20007\%20-\%20 europe\%202020\%20- \%20en\%20version.pdf, (accessed: September 2017). Also worth mentioning is the Agenda for New Skills and Jobs, Communication from the Commission, An Agenda for New Skills and Jobs: A European Contribution towards Full Employment', Strasbourg 23.11.2010, COM (2010)682 final, available at: http://eur-lex.europa.eu/LexUriServ/LexUriServ.do?uri= COM:2010:0682:FIN:EN:PDF, (accessed: September 2017).

4 Council Recommendation on the 2016 national reform Programme of Poland and delivering a Council opinion on the 2016 convergence Programme of Poland, pp. 4-6, available at: http://ec.europa.eu/europe2020/making-it-happen/country-specific-recommendations/index_pl.htm (accessed: 1.02.2017), Commission Recommendation for Poland, Brussels 18.05.2016, $\operatorname{COM(2016),~341,~available~at:~http://ec.europa.eu/~}$ europe2020/pdf/csr2016/csr2016_poland_en.pdf. (accessed: 1.07.2017).

5 The detailed information about programmes is provided by B. Błaszczyk, Sytuacja osób starszych na rynku pracy w Polsce, "Gerontologia Polska" 2016, no. 24, pp. 51-57, available at: http://gerontologia.org.pl/wp-content/uploads/2016/05/Gerontologia-Polska_1_2016.pdf, (accessed: September 2017); A. Zbyszewska, Sustainability, Active Aging through Employment and the Question of Care in Poland. A Social Reproduction Perspective, 9-11, draft paper, available at: https://ecpr.eu/Filestore/PaperProposal/ a31ae2ac-bedd-4590-85c8-897bce0b5e01.pdf (accessed: 1.06.2017).

6 Among the lastly published contributions we should mention in particular: J. Czapiński, P. Błędowski, Aktywność społeczna osób starszych w kontekście percepcji Polaków. Diagnoza społeczna 2013, Warszawa 2014, http://www.diagnoza.com/pliki/raporty_tematyczne/Aktywnosc_spoleczna_osob_starszych.pdf, (accessed: September 2017); P. Szukalski, Ludzie bardzo starzy - niewidoczna grupa docelowa polityki spotecznej?, "Studia Demograficzne" 2014, vol. 2 (166), pp. 59-62, available at: http:// dspace.uni.lodz.pl/xmlui/bitstream/handle/11089/11159/SD\%202014-2_Szukalski. pdf?sequence=1\&isAllowed=y (accessed: 1.06 .2017 ). See also the remarks related to tle lowering of retirement age since 1 November 2017: R. Pacud, Utracona sprawiedliwość międzypokoleniowa w ubezpieczeniu emerytalnym?, "Praca i Zabezpieczenie Społeczne" 2016, no. 2, pp. 2-9. See also the articles in which were presented the earlies contributions related to analysed topic: T. Wrocławska, Employment Permanence (Stability) 
In consideration of the above, it is necessary to emphasise the dynamic nature of the process of measures aimed at ensuring a gradual generational shift and implementing the principle of intergenerational solidarity. Therefore, despite earlier research carried out by Polish scientists related to the issues presented in the study, ${ }^{7}$ there is still a clear need to undertake further scientific efforts as well as to implement new research assumptions - an example of which is presented in the study.

In the presented publication, the analysis of solutions applied in selected countries was carried out in order to attempt to provide a model view of legal measures to counteract unemployment among the older person. Different methods of research specific to legal comparative studies were used, ranging from formal-dogmatic, functional, to logical and statistical.

In accordance with the adopted research assumptions, a comparison of the legal regulations in force in the following countries was performed: Lithuania, Czech Republic, Slovakia and the Netherlands. Due to the framework of the study, a detailed description of Polish regulations was abandoned. The emphasis here should be placed on the multidimensionality of the subject matter. Particular aspects concerning the situation of the older person in the perspective of Polish legislation have been discussed in previous works published under the ongoing grant. They also draw on the rich achievements of Polish doctrine. The above studies analysed such issues as the prohibition of discrimination on the grounds of older age, ${ }^{8}$ protection of the sustainability of the employment relationship of people at pre-retirement

of Employment Relationship of Older Employees - Analysis of Changes, [in:] I. Florczak, Z. Góral (ed.), Developments in Labour Law From a Comparative Perspective, tódź 2015, pp. 99-118, T. Wrocławska, Idea międzypokoleniowego podziału pracy jako kryterium obowiq̨zkowego przejścia na emeryturę w świetle stanowiska Trybunału Sprawiedliwości UE, [in:] T. Bińczycka-Majewska, M. Włodarczyk (eds.), Współczesne problemy prawa emerytalnego, Warszawa 2015, pp. 109-133, T. Wrocławska, Kodeksowa szczególna ochrona trwałości stosunku pracy pracowników w wieku przedemerytalnym, [in:] Z. Góral, M. Mielczarek (eds.), 40 lat Kodeksu pracy, Warszawa 2015, pp. 154-176.

7 The comparative studies which were conducted recently: E. Kryńska, P. Szukalski (eds.), Rozwiqzania sprzyjające aktywnemu starzeniu się w wybranych krajach Unii Europejskiej. Raport końcowy, Łódź 2013; E. Kryńska, I. Kukulak-Dolata, I. Poliwczak, K. Wojtaszczyk, Perspektywa instytucji rynku pracy, [w:] E. Kryńska, J. Krzyszkowski, B. Urbaniak, J. Wiktorowicz (eds.), Diagnoza obecnej sytuacji kobiet i mężczyzn 50+ na rynku pracy w Polsce. Raport końcowy, Łódź 2013, E. Kryńska (ed.), Elastyczne formy zatrudnienia i organizacji pracy a aktywność zawodowa osób starszych. Raport syntetyczny w ramach projektu: Badanie wpływu elastycznych form zatrudnienia i organizacji pracy na aktywność zawodowa zasobów pracy w wieku 45+, Warszawa 2013, pp. 138140, P. Błędowski, B. Szatur-Jaworska, Z. Szweda-Lewandowska, P. Kubicki, Report on the Situation of Older in Poland, Warszawa 2012, available at: http://senior.gov.pl/ source/raport_osoby\%20starsze.pdf, (accessed: September 2017).

8 T. Wroctawska, Non-discrimination Principle and the Need for Special Treatment of Older Employees (Considerations Based on Polish Statutory Regulations), WEI International Academic Conference Proceedings 2015, available at: https://www.westeastinstitute. 
age and those undergoing retirement, ${ }^{9}$ the impact of retirement age on work performance, ${ }^{10}$ active measures to counteract unemployment among the older age groups, ${ }^{11}$ health protection of older people in view of the increased risk of chronic diseases ${ }^{12}$ and the use of fixed-term contracts of employment when hiring older persons..$^{13}$ The final conclusions of the presented part contain remarks, which take into account the Polish context.

com/wp-content/uploads/2016/05/Tatiana-Wrocławska-1.pdf, pp. 105-110, (accessed: September 2017).

9 T. Wrocławska, Glosa do wyroku Sadu Najwyższego z dnia 16 lutego 2017 r., II PK 375/15, “Orzecznictwo Sądów Polskich" 2017, no. 11, pp. 175-182; T. Wrocławska, Uwagi na tle wyroku SN z dnia 18 grudnia 2014 r., II PK 50/145, "Gdańsko-Łódzkie Roczniki Prawa Pracy i Prawa Socjalnego" 2016, vol. 6, pp. 229-238.

10 T. Wrocławska, The Right to Choose or Having No Choice: Retirement or Employment. Dilemmas Related to Old Age (Remarks Based on Polish Legal Regulations), "Economic and Environmental Studies" - an article was sent to publisher.

11 T. Wroctawska, The Analyses of the Legal Measures Taken to Combat Unemployment (to Boost Employability) Among Older People According to the Last amendments of the Polish Law on Employment Promotion and Labour Market Institutions, [in:] T. Davulis, P. Lang (eds.), Labour Law Reforms in Eastern and Western Europe, Brussels 2017, pp. 431-453.

12 T. Wrocławska, Protection and Guarantees for Older Employees with Chronic Diseases (Cancer) through Labour Legislation in Poland - an article sent to publisher.

13 T. Wrocławska, Umowy na czas określony a zatrudnienie osób starszych, [in:] M. Mędrala (ed.), Terminowe umowy o pracę, Warszawa 2017, pp. 221-239. 


\section{Legal measures for supporting employment and return to work of older people in Lithuania, Czech Republic, Slovakia and Netherlands}

\subsection{The general remarks related to population ageing and active participation of older at the labour market}

According to national statistics, Lithuania is increasingly experiencing a population aging process: the share of aged 65 and older in the overall population is increasing, while the overall population decreases. According to information provided by The Lithuanian Statistics Office, the country had 2943.5 thousand inhabitants at the beginning of 2014, of which, 542,700 (18.4\%) were aged 65 and older. Over the ten years between (2004-2013) their number increased by 18.6 thousand (3.5\%), and their share in the total population by 3 percentage points, while the overall population decreased by 455.5 thousand (13.4\%). It is also noted that the number of older women is almost twice as high as older men. In 2014, every seventh male and every sixth woman in Lithuania was over 65. ${ }^{1}$ At the beginning of 2014 there were 182.4 thousand (33.6\%) men and 360.3 thousand (66.4\%) women aged 65 and older. It is predicted that by the beginning of 2050, Lithuania will have about two million (1 million 910 thousand) inhabitants, of which over half a million (544.5 thousand), or $28.5 \%$ of the total population, will be made up by this age group. In comparison, in 2013, $18.2 \%$ of the European Union's population was over 65 years. Higher rates were observed in Italy (21.2\%), Germany (20.7\%), Greece (20.1\%) and Portugal (19.4\%); the lowest were noted in Ireland (12.2\%), Slovakia (13.1\%) and Cyprus (13.2\%). Statistics, as of May $1^{\text {st }}, 2015$, also show that among the 155.6 thousand registered unemployed persons, $20 \%$ were over the age of 54, with one out of every two being long-term unemployed, ${ }^{2}$ (Article 2 (11) of law on Support for Employment). ${ }^{3}$ The term 'long-term unemployed' covers persons over 25 if they remain unemployed for more than 12 months from the date of their registration at the labour office (for persons under 25 the period is over 6 months). The above data confirms not only the rise in average life expectancy, but also the need to prolong the activity of the older person on the labour market, meaning both pre-retirement aged people and those of a pensionable age.

1 The presented data, authored by G. Burokaite was accessed: http://ec.europa.eu/ eurostat/web/ess/-/older-people-in-lithuania (accessed: January 2016). The data is presented in Pagyvene zmones Lietiuvoje, Elderly People in Lithuania, Vilnius 2014 (December), p. 8.

2 Ibidem.

3 Lietuvos Darbo Birza, Projektas "Ilgalaikių bedarbiu jdarbinimo rėmimas", https://www. Idb.It/Informacija/ESParama/Puslapiai/esf_ilgalaik_bedarb_remimas.aspx (accessed: January 2016). 
The assessment of the situation of older people in the Lithuanian labour market, ${ }^{4}$ conducted in 2013, indicated that the main barriers to their remaining on the labour market were as follows: insufficient flexible solutions due to the fact that the Labour Code of the Republic of Lithuania does not provide for specific solutions related to shorter working hours for the older worker, lack of legal regulations connected to part-time work for older workers, working conditions not tailored to their needs, little interest in both improving qualifications and lifelong learning (in 2010 the rate of participation of people aged 55-74 in lifelong learning (LLL) in Lithuania was six times lower than the EU average), lack of labour market services addressed exclusively at the older person, negative attitude of employers towards them due to their lower qualifications and lack of knowledge of foreign languages, health problems, lack of motivation, fear of change and new challenges. 5

4 R. Zabarauskaitè, I. Blažienè, Lithuania: Role of social dialogue in industrial policies, https://www.eurofound.europa.eu/observatories/eurwork/comparative-information/ national-contributions/lithuania/lithuania-role-of-social-dialogue-in-industrial-policie, (accessed: January 2016).

5 It should be indicated that projects co-financed by the European Social Fund constitute a particular type of support for groups of older unemployed people. These include labour market services available to different groups but often aimed at a particular target group of the unemployed. A good example is the program addressed only to persons $55+$, entitled "Support for unemployed persons in old age", implemented over the period of 2015-2017. Only persons who have reached the age of 55 who are registered at the labour office may participate in the project. Training, subsidised employment and movement between regions of the unemployed were mentioned among the measures aimed at promoting the employment of these persons. Currently, only slightly more than 1,000 unemployed persons have benefited from the support offered. However, the objective is to help 14 thousand people into employment (Lietuvos Darbo Birza, ESF projektas "Vyresnio amžiaus bedarbių rèmimas”, https://www.ldb.lt/ Informacija/ESParama/Puslapiai/vyresnio_amziaus_bed_remimas.aspx, accessed: January 2016). Another project addressed, among others, to persons 55+, entitled "Learn a suitable profession", was focused on vocational training. The implementation period of the project was 2014-2016. Other projects aimed at retaining people on the labour market (where one of the target groups are those 50+ who are unemployed and of working age) are also worth mentioning. The project entitled "Stay on the labour market" was implemented in the years 2014-2015. Due to the objective identified in the project, the means of its implementation include vocational education, subsidized employment, promotion of the acquisition of occupational skills in the workplace and temporary replacement (https://www.ldb.lt/Informacija/ESParama/Puslapiai/esf_islik_darbo_rinkoje.aspx, accessed: January 2016). Among projects financed from the European Social Fund, "Assistance in employment" (successfully completed in 2014) deserves a mention; it was addressed to persons covered by additional support on the labour market. The project offered subsidized employment services and supported the acquisition of vocational skills for the workplace (Lietuvos Darbo Birza, Projektas "Pagalba isidarbinant", https://www.Idb.It/Informacija/ESParama/gyvendinti\%20 ES\%20projektai/UserDispForm.aspx?ID=29, (accessed: January 2016). 
The demographic situation in the Czech Republic is also not favorable. The increase in average life expectancy with the associated population growth above 65 shows a strong growing trend. ${ }^{6}$ The Czech Republic is inhabited by over 10 million people; women predominate, providing $61 \%$ of the adult population. In 2011, the average lifespan for men was 75 years and for women 81 . This puts the Czech Republic between the so-called Eastern Bloc and western countries. Persons over the age of 65 represent around $16 \%$ of the population, constituting a more numerous group than children aged $0-14$ (14\% of the population). In addition, according to data for 2013, there are about 5 million professionally active people and about 1.7 million pensioners in the Czech Republic, thus, there is roughly a ratio of three working people for one that is retired. ${ }^{7}$ As far as the employment situation of pensioners is concerned, in addition to employment within the framework of an employment relationship, self-employment and gainful activity are also relatively common. ${ }^{8}$ The popularity of these forms of employment is due to the society's growing awareness of the possibility to combine paid retirement with work. About one quarter of employed pensioners, especially men, continue to work within the framework of so-called self-employment. Part-time employment, on the other hand, is widespread among women (about $60 \%$ of female pensioners work parttime). It is also noted that despite the high percentage of working pensioners, one third of them work in the so-called gray area. ${ }^{9}$

In Czech Republic during the years 2001-2009, the employment of older persons showed a strong upward trend. ${ }^{10}$ However, according to data for 2009, the employment of men aged 55-59 was $77.9 \%$, while the result for women was $53.7 \%$; employment of men aged 60-64 was $36.5 \%$, whereas women at that age - only $14.6 \%{ }^{11}$ Data for more recent years are similar. This is also true for people over 65. The data confirm also the rather high and increasing level of employment and

6 See the table showing the survey results: https://www.unece.org/fileadmin/DAM/ pau/age/WG8/Presentations/8-Active_Ageing_Czech_Republic.pdf, p. 4, (accessed: September 2017). See also: The 2015 Ageing Report, European Commission, European Economy8/2014, UE 2014, p. 382, http://ec.europa.eu/economy_finance/publications/ european_economy/2014/pdf/ee8_en.pdf, (accessed: September 2017).

$7 \quad$ R. Andel, Aging in the Czech Republic, "The Gerontologist" 2014, vol. 54, no. 6, pp. 893894, https://academic.oup.com/gerontologist/article/54/6/893/565685/Aging-in-the-Czech-Republic, (accessed: September 2017).

8 It should be emphasized that in the Czech Republic, so called small entrepreneurs, employing from 1 to 9 employees, dominate. They constitute about 95\% of all enterprises in the Czech Republic. Recent studies also show a sharp increase in self-employment. More information L. Vidovićová, Conceptual Framework..., p. 35

9 L. Vidovićová, Conceptual Framework..., pp. 33-35.

10 L. Vidovićová, Extending Working Life and Active Impact in the Czech Republic p. 4, http://mopact.group.shef.ac.uk/wp-content/uploads/2013/10/Country-report-Czech-Republic.pdf, (accessed: September 2017).

11 L. Vidovićová, Conceptual Framework of the Active Ageing Policies in Employment in Czech Republic CASE Research Paper No. 469/2014, p. 14, https://papers.ssrn.com/sol3/ papers.cfm?abstract_id=2406880, (accessed: September 2017). 
the low unemployment of people over $65 .{ }^{12}$ The $2013-2060$ projection for occupational activity of people over 55 shows similar upward trends. ${ }^{13}$ Within Central and Eastern European countries on the active aging index (AAI), the Czech Republic places 12 th out of a total of 28 (a similar position to Estonia). It should be emphasized that in the four domains (employment, social participation, independent living, and participation in active aging) identified for the purpose of the study being conducted, ${ }^{14}$ individual indicators are at an average level. Despite a similar number of points (Estonia - 34.8 and Czech Republic - 34.6), the Czech Republic scores better. ${ }^{15}$ Also noticeable is the gradual increase of the index from 30 to 30.6 points when compared to 2012, which means that changes introduced or implemented during the period of the last study should be assessed positively.

12 OECD, Labour Force Statistics 2016, Czech Republic, Paris 2017, p. 60, http://www.keepeek.com/Digital-Asset-Management/oecd/employment/oecd-labour-force-statistics-2016/czech-republic_oecd_Ifs-2016-8-en\#.WWCg9Lgso7Q\#page1, (accessed: September 2017).

13 See The 2015 Ageing Report..., p. 382. It is noteworthy, that as the research on the direction of action taken by the government and its social partners to keep older people in the labour market show, particular attention was paid to reforms of the pension system and changes in Czech legislation aimed at prolonging the gainful activity of older workers (both pre-retirement and pensionable age persons). It noted that there is a lack of legislation providing for specific legal measures to support the employment of people over 50, as active labour market policies are applied to all age categories and are not intended as mandatory solutions in relation to older people. Taking into account the fact that the percentage of the population aged 50-64 will soon become the most numerous age group in Czech society, the need to introduce specific legal solutions that will lead to an increase in employment of people from this age group was emphasized. This was reflected in the project entitled "Age Management Strategy in the Czech Republic", implemented in 2010-2012. With regard to policies at a national level, the programme 'National Strategy for Active Ageing 2013-2017' deserves attention, with its significant emphasis on health aspects and lifelong learning. In addition, the need to implement projects that promotes "mentoring" and creates teams of employees with a broad age spectrum in workplaces, as well as the need for age management as part of the lifelong learning concept were underlined. It also pointed out the need to review the Occupational Safety and Health (OSH) legislation with the need to consider changes adapted to the protection of the safety and health of older workers. (J. Hála, Czech Republic: The Role of Governments and Social Partners in Keeping Older Workers in the Labor Market, https://www.eurofound.europa. eu/observatories/eurwork/comparative-information/national-contributions/czech-republic/czech-republic-the-role-of-governments-and-social-partners-in-keeping-older-workers-in-the-labour, accessed: 2.06.2013).

14 See: UNECE, AAI 2014, Active Ageing Index for 28 European Countries, November 2014, http://www.unece.org/fileadmin/DAM/pau/age/WG7/Documents/Policy_Brief_AAI_ for_EG_V2.pdf, (accessed: January 2016).

15 Estonia occupies second place in the employment domain and takes 11th place in the overall ranking. However, in the remaining domains, it was granted significantly less points. ibidem, p. 5. 
When comes to Slovakia, according to EUOSTAT data people aged 65 and over represented $13.3 \%$ of the total population in Slovak Republic in 2013. However, according to the projected data for 2020, this age group will account for in the region of $16.9 \%$ of the total population. In subsequent five-year periods, an average increase of 2 percentage points is expected. Economic activity among people aged 55-64 in 2013 amounted to 49.6\%, whereas in the next five-year periods an increase of 2-3 percentage points is expected. The percentage of people aged 5564 in the working age population (15-64 years) in 2013 was $18.9 \%$, with a significant increase, according to the prognosis, expected to occur from 2025.16

According to further data in 2014, the employment rate of people aged 5564 in Slovakia was below the EU average and amounts to $44.8 \%$. This is still favourable, however, when compared to Poland (42.5\%). As regards the countries surveyed, Slovakia is behind the Czech Republic (54.0\%), Lithuania (56.4\%), Latvia (56.4\%), the Netherlands (60.8\%) and Estonia (64.0\%). Sweden (74.0\%) and Germany $(65.6 \%)$ report the highest results. ${ }^{17}$

The presented statistics also show a noticeable difference in employment on the grounds of gender. Slovakia is one of the countries where this difference amounts to a sizeable margin of percentage points. The employment rate for men is $53.1 \%$, while for women it is only $37.2 \%$. A similar situation is reported in Poland (men - 53.1\%, women - 32.9\%), the Czech Republic (men - 64.8\%, women - $43.8 \%$ ), and, interestingly, the Netherlands (men - 70.7\%, women - 50.8\%). The employment rate gap is slightly lower in Estonia (men - 65.1\%, women - 63.1\%). There is little significant difference in the remaining countries surveyed. For example, in Lithuania, the employment rate for men was $58.8 \%$ and for women $54.3 \%$. It is interesting to note that while in the aforementioned countries the employment rate of men is higher than that of women, in Latvia female employment levels are higher, admittedly, the advantage is slight, being $56.4 \%$ in comparison with the employment rate of men, which is $56.3 \% .18$

What is need to be highlighted, in the Slovak Republic, according to the data presented in the literature, ${ }^{19}$ there is a steady increase in employment of older people

16 European Commission, The 2015 Ageing Report, "European Economy" 2015, no. 3, Economic and Financial Affairs, Economic and budgetary projections for the $28 \mathrm{EU}$ Member States, Luxembourg 2015, p. 370, available at: http://ec.europa.eu/economy_finance/ publications/european_economy/2015/pdf/ee3_en.pdf, (accessed: September 2017).

17 Eurostat News release, Employment Rates for the Age Group 55-64, Europe 2020 Employment Indicators, 81/2015 - 7 May 2015, available at: http://ec.europa.eu/eurostat/ documents/2995521/6823708/3-07052015-AP-EN.pdf/7e507ea0-43c7-452f-8e6ab479c89d2bd6, (accessed: September 2017).

18 Ibidem.

19 European Employment Observatory Review, Employment Policies to Promote Active Ageing 2012, Luxembourg: 2012, L. Vagač (Centre for Economic Development), Slovakia, p. 40, available at: https://www.ifa-fiv.org/wp-content/uploads/2015/03/6-EU-Active-Ageing-2012.pdf, (accessed: September 2017). See in particular the study of this author, European Employment Observatory, EEO Review: Employment Policies to Promote Active 
aged 55-64. Analysis of the years 2000-2010 also shows a strong upward trend in Slovakia in relation to the European Union average, with the 2010 employment rate for men being similar to the EU average. An increase in female employment is also noticeable. This is the consequence of the pension reforms and the prolongation of the retirement age. However, despite the gradual increase in the retirement age, the age at which people decide to retire remains relatively low compared to the European Union average. In the case of women, it is 57.5 years in the analysed period, while in the case of men it is 60.4 years. This is explained by the low employment rate of older people aged 60-64 and people over 65 .

The unemployment rate of older workers in Slovakia is also relatively high, with, respectively, $11.4 \%$ and $7.3 \%$ for men and women in the 55-59 age group. National data from the period under investigation also show that people approaching retirement age were at risk due to the effects of the economic crisis. The low level of active participation of the older person in the labor market is due to the following factors: early exit from the labour market (early retirement expenditure in Slovakia is the highest in the European Union), lack of qualifications (especially language skills and those connected to the IT industry), low participation of adults in education, and the predominance of atypical forms of employment; as well as age discrimination and the low effectiveness of active labour market policies.

Netherlands, like the abovementioned European countries, also experiencing the phenomenon of the rapid growth of its older population. Its share in the total population of the country in 2013 amounted to $17.1 \%$, while, according to the projected data in 2060 , they will constitute about $27.4 \%$ of the total population. ${ }^{20}$

Over the past ten years, in Netherlands a number of reforms aimed at curbing early retirement and raising the retirement age have been implemented. ${ }^{21}$

Ageing, 2012, Slovakia, February 2012, p. 2, available at: www.ec.europa.eu/social/Blo bServlet?docld=12258\&langld=en, (accessed: September 2017).

20 The predictions concerning those aged over 80 are similar. According to the data for 2013 , they now provide $4.2 \%$ of the population as a whole, which is expected to increase to $11.1 \%$ in 2060. See European Commission, The 2015 Ageing Report, Luxembourg 2015, p. 370.

21 Noteworthy are also agreements made between Government of the Netherlands and the social partners, the Budget Memorandum 2014 should be distinguished. It includes proposed solutions aimed at, e. g. later retirement and incentives to take up employment (the implementation of the solutions indicated in the programme has been suspended until the implementation of the set objectives in 2016, OECD, Working Better with Age, Netherlands..., p. 2). The agreement, signed in 2017 by the employers of the metallurgical sector with the Confederation of Trade Unions, is intended to increase the employment of young people. The agreement, called the Generation Pact, will remain in force until July 1,2019 , and allows for reduced working hours for those in pre-retirement age to encourage the hiring of the young (C. Galli da Bino, M. Blomsma, Netherlands: Latest working life developments - Q2 2017, Eurowork, European Observatory of Work, https://www.eurofound.europa.eu/en/observatories/eurwork/articles/netherlands-latest-working-life-developments-q2-2017, accessed: 2.08.2017). The below are presented progmammes and legal acts which were the consequence 
This has resulted in the growth of employment of those in the age group 55-64 by 17 percentage points in the period between 2002 and 2012. In 2012, the employment of people in this age group was $58.6 \%$. The employment rate of people aged 65-69 in 2012 stood at the level of $12.7 \%$, presenting a considerable increase over

of the provided changes. The "Sustainable Employability" programme, introduced in April 2012 as a consequence of the government's agreement with the social partners, also deserves a mention. The main objectives of this programme are health care, protection against unemployment and the application of, so-called, good practices by employers (OECD, Working Better with Age, Netherlands..., p. 7) In the area of adult education programmes, the "Count on Skills" program (Tel Mee Met Taal), aimed at developing language skills, and implemented until 2018, is worth highlighting. Thanks to these education programs, the participation of adults in lifelong learning increased to $18.9 \%$ in 2015 , whereas the European Union average was only $10.7 \%$ during the period under review (European Commission 2016, Education and Training Monitor, Netherlands, as of available at: https://ec.europa.eu/education/sites/education/files/ monitor2016-nl_en.pdf, accessed: 15.09.2016). The main reforms linked to the removal of the differences between fixed-term and permanent employment took place in 2015, by the adoption of the Work Security Act (Wet Werk en Zekerheid) The main aim was to create more permanent employment opportunities for people with fixed-term employment, while in the case of permanent workers, attention was paid to the development of greater employment dynamics, inter alia by encouraging transitions from one job to another (N. Gundt, The Protection of Unemployed Persons in the Netherlands, [in:] T. Bazzani, R. Singer (eds.), Security in the EU. An Overview of the Passive and Active Labour Market Policies in the Netherlands, Poland, Italy, Spain and Greece, Berlin 2016, p. 17). However, at present there is no data on whether the increase in permanent employment is the consequence of the adoption of the abovementioned law (European Commission, Brussels, 22.2.2017, SWD (2017) 84 final..., p. 31). In the literature, we can also see that the law resulted in the opposite of its intended effect, as instead of simplifying the dismissal procedure, it complicated it (N. Gundt, The protection of unemployed..., p. 38). Particular attention should also be paid to the adoption of the Participation Act (Participatiewet). in 2015. The law aims not only to provide a certain social minimum income but primarily to move people out of poverty as quickly as possible (More details N. Gundt, The protection of unemployed..., p. 24). On the basis of this strategy, local governments took over responsibility for groups classified as particularly at-risk in the labour market. They offer a wide range of support solutions aimed at removing barriers to reintegration into the labour market, including language courses, developments in childcare and housing assistance (European Commission, Brussels, 22.2.2017, SWD (2017) 84 final..., p. 29). The Act on Unemployment Benefits should also be mentioned. Benefits are paid on the condition that a person is qualified as an unemployed person within the meaning of the Act, as well as that the conditions related to, among other things, seniority entitling him/her to benefit are fulfilled. As a result of the quite significant changes to the Act in 2015, shortened periods of benefit payments now apply. The basic period of payment of benefits is three months, although the payout period may be extended on the condition that the so-called 'relevant employment history' is shown. Studies also stress that early exit from the labour market is widespread in the Netherlands. In order to counteract this practice, as many as 24 collective agreements (in 2010) included clauses relating to policies aimed at raising the awareness of age (age-aware HR-policies) and the risks relating thereto, in particular by eliminating phenomena and practices aimed at direct 
the 2002 rate of $6.5 \%$. This was still behind the 2012 OECD average of $19.3 \%$. Nonetheless, the Netherlands is among the countries that have made significant progress in this respect. ${ }^{22}$ The measures introduced have also led to an increase in the age at which people leave the labour market, especially for women. For 2012, the average age of leaving the labour market for men was 63.6 years, while for women it was 62.3 years. $^{23}$

The employment rate for older people in the Netherlands for 2016 was $63.2 \%$ of the total population aged 55-64. In comparison to previous years, from 2011 onwards (with a slight slowdown in 2014), the increase rose on average by 2 percentage

or indirect discrimination on the grounds of age. Collective agreements began to introduce age-based employment clauses, with the majority of the measures addressed at older workers. Attention should also be drawn to the provisions of collective agreements on training and education, as well as on health, particularly in relation to the entitlement to medical care which is usually enjoyed by older people (More on this R. van het Kaar, F. Tros, The Netherlands: The role of governments..., p. 7). In the area of health protection and safety in the workplace, the STAR Foundation has issued recommendations for the periodic examination of older workers. This has led, among other things, to the development at the sectoral level of institutions of the so-called 'catalogues' specifying working conditions, including, among other things, the assessment of occupational risk in relation to older workers (Arbo Catalogues). In spite of their wide application, it should be stressed that only $3 \%$ of the abovementioned catalogues contained specific measures addressed to older people. In addition, the limited involvement of employers in the adaptation of jobs to the needs of older workers was also highlighted. Human resource management (HRM) policies in the Netherlands which are based on collective agreements have been assessed positively. The main measures under their strategy include additional provisions on leave, part-time work and partial retirement (ibidem, pp. 5-6). The STAR recommendations in support of partial retirement are particularly noteworthy. These recommendations have resulted in the rise of number of collective agreements containing clauses ( $a$ la carte clauses) through which individual employers offer targeted working conditions. In many collective agreements, older workers were also entitled to more days off. The introduction of a partial pension clause in some collective agreements, as well as the promotion of equal treatment and the prohibition of discrimination against older people, should be welcomed.Particular attention should also be paid to those of them which provide for individual solutions adapting, among other things, the transition to part-time work. Even though such solutions were addressed to all employees, in practice they were mainly used by older people). It was also pointed out that the measures aimed at older people (such as curtailing overtime, reduced working hours or extra days off work) in fact can also reinforce any negative perception of older people and limit their opportunities. Employers are also sceptical about implementing them owing to the rise in employment costs R. van het Kaar, F. Tros, The Netherlands: The role of governments..., pp. 6-7).

22 OECD, Working Better with Age, Netherlands, Assessment and Main Recommendations, April 2014, p. 1, available at: https://www.oecd.org/els/emp/Older\%20Workers\%20 NETHERLANDS_Assessment\%20and\%20main\%20recommendations.pdf, (accessed: September 2017).

Ibidem. 
points. ${ }^{24}$ However, it is noted that the increase in the number of persons employed may be caused primarily by the consequence of an increase in the number of individuals employed under fixed-term employment contracts and within the framework of so-called self-employment. The popularity of these forms of employment is a result of the differences in legal regulations when compared to permanent contracts. Self-employed people are often excluded from disability insurance and unemployment insurance, therefore, the EU Council recommended that measures should be taken to increase employment on a permanent basis, as well as on tax and social protection arrangements for self-employed people. ${ }^{25}$ It has also been noted that the proportion of part-time workers in the Netherlands is among the highest in OECD countries. This is especially true for older women aged 50-64 (64\%). ${ }^{26}$ Moreover, according to recent data, around $80 \%$ of workers aged 65 and over work in flexible forms of employment, with self-employment being the most common. ${ }^{27}$ Due to the existing regulations on the automatic termination of employment contracts when reaching the retirement age, there is a relatively low percentage of people of retirement age in the labour market (about 13\% of the total number of people aged 65-69). ${ }^{28}$

The rate of participation of older people in the labour market in Netherlands is, however, accompanied by long-term unemployment among workers aged 50-74.29

24 European Commission, Commission Staff Working Document, Country Report, The Netherlands 2017: Including an In-depth Review on the Prevention and Correction of Macroeconomic Imbalances, Brussels, 22.2.2017, SWD (2017) 84 final, p. 50, available at: https://ec.europa.eu/info/sites/info/files/2017-european-semester-country-report-netherlands-en.pdf, (accessed: September 2017).

25 European Commission, Brussels, 22.5.2015, COM (217) 518 final, Recommendation for a Council Recommendation on the 2017 National Reform Programme of the Netherlands and Delivering a Council Opinion on the 2017 Stability Programme of the Netherlands, p. 4, available at: https://ec.europa.eu/info/sites/info/files/2017-european-semester-country-specific-recommendations-commission-recommendations_-_netherlands. pdf, (accessed: September 2017).

26 OECD, Working Better with Age, Netherlands..., p. 11.

27 ETUI, News, Netherlands: Marked Increase in Flexible Workers, 10 April 2017, available at: https://www.etui.org/News/Netherlands-marked-increase-in-flexible-workers.

28 R. van het Kaar, F. Tros, The Netherlands: The Role of Governments and Social Partners in Keeping Older Workers in the Labour Market, p. 209, available at: https://www.eurofound.europa.eu/observatories/eurwork/comparative-information/role-of-governments-and-social-partners-in-keeping-older-workers-in-the-labour-market (accessed: 2.06.2013).

29 According to presented data, the long-term unemployment rate is highest for people over 45. In 2014 more than half of the long-term unemployed were between 45 and 65. This is also the largest group receiving unemployment benefits and social benefits. B.-J. Buiskool, S. Broek, G. Dente for Policy Department A: Economy and Scientific Policy, The Social and Employment Situation in the Netherlands and Outlook on the Dutch EU Presidency 2016, European Parliament, PE 563.473, p. 3, available at: http://www.europarl.europa.eu/RegData/etudes/BRIE/2015/563473/IPOL_BRI(2015)563473_EN.pd, (accessed: September 2017). 
This rise occurred between 2009-2015 and remains high despite the introduction and application of the range of solutions to counteract this phenomenon. It is pointed out that the reasons for such a situation may be the high employment costs for employers associated with employing older people. In response, the Government of the Netherlands, in cooperation with the social partners, has decided to launch an action programme to strengthen the position of older people over 50 years old on the labour market, to be implemented between 2017-2018..$^{30}$

According to data for 2012, the main obstacles to prolonging occupational activity in Netherlands include high long-term unemployment, low mobility and a high proportion of people with disabilities. ${ }^{31}$ It is also noted that due to significantly higher wages for people aged 55-59, employers are more likely to employ young people. ${ }^{32}$ As far as working conditions are concerned, around $75 \%$ of people aged 55 and over considered them acceptable according to the survey conducted in $2012 .{ }^{33}$

\subsection{Legal regulations for supporting employment of older people}

The new Lithuanian Labour Code was adopted by the Lithuanian Parliament on 14 September 2016, ${ }^{34}$ and entered into force on January $1^{\text {st }}, 2017$. The main objective was the liberalization of employment relationships and the introduction of flexible work arrangements, as well as strengthening the role of the social partners. ${ }^{35}$ It was noted that the possibility for persons of pre-retirement age to resume work practically did not exist. This was particularly true of persons whose contracts were terminated at pre-retirement age. ${ }^{36}$

It is worth emphasizing that under the Lithuanian Labour Code prior to 2017, despite the diversity of employment protection mechanisms, there was subjective differentiation among persons of pre-retirement age. The legislation concerning the termination of employment contracts referred either to employees with no more than 5 years remaining until they acquired the right to a full pension, or persons with less than 3 years before they were entitled to a partial retirement pension.

30 European Commission, Commission Staff Working Document, Country Report, The Netherlands 2017, Brussels, 22.2.2017..., p. 29.

31 OECD, Working Better with Age, Netherlands..., p. 1.

32 Ibidem, p. 5.

33 Ibidem, p.10.

34 No. XII-2603. The text of the new code is available at: https://e-seimas.Irs.It/portal/ legalAct/en/TAD/TAIS.191770 (accessed: 1.07.2017).

35 D. Petrylaite, Four Years of Lithuanian Labour Reforms, Lithuanian National Report, pp. 8-9, available at: http://islssl.org/wp-content/uploads/2014/08/Lithuanian-National-Report.pdf (accessed: 1.07.2017).

Ibidem. 
However, general provisions for those groups of employees additionally supported on labour market referred to those employees with no more than 5 years left before being eligible to a pension, without specifying whether the person involved benefits from a full or partial retirement pension.

The amendments of the Lithuanian Labour Code show the rather limited nature of the provisions relating to the employment of older workers, as they receive few extra rights. These include the priority to remain in employment in cases of redundancies and longer notice periods due in pre-retirement age. Reaching retirement age and acquiring the right to a full pension was considered to be a reason for exclusion from the priority to remaining in employment; the same circumstance is treated by the legislator as a reason for the termination of the employment contract by the employee with five days' notice, together with the employer's obligation to pay retirement severance amounting to one's monthly wage. In certain situations, although they are not significant, the legislator provides people with health problems or a determined degree of disability additional assistance, which is exemplified by the regulations on part-time work or telework, as well as by granting holiday leave as far as its length and priority consideration is concerned (Article 128 of the Lithuanian Labour Code). People with family responsibilities are also afforded additional rights, albeit to a limited extent. Seniority (length of service) as a preferential criterion granting privileges occurs in the regulations with reference to severance pay due from the employer and from the state. Seniority is also taken into account during the process of evaluating candidates for redundancy. Other provisions concerning both the flexible forms and legal bases of labour provide the possibility of increasing the employment of older people, albeit without explicitly addressing employees of retirement or pre-retirement age, as they apply to employees of all ages. Part-time employment contracts, telework contracts and job-share are particularly useful in this respect. To sum up, apart from the aforementioned exceptions there are no specific legal regulations relating to the employment of persons in pre-retirement age or pensioners. Having said that, more favorable provisions may be introduced under collective agreements. In practice, this means that solutions such as entitlement to a 'seniority allowance' as well as longer leave for older employees may be implemented.

The Czech Labour Code of 21 April $2006^{37}$ does not use the definition of an older person. It also lacks the provisions for protection against dismissal in the case of persons of pre-retirement age. This applies not only to normal cases of dismissal by notice, but also to the termination of employment relationships in the event of collective redundancies.

The avovementioned statutory regulation contains a list of reasons which justify termination of the employment contract by notice. These include reorganisation reasons, prolonged incapacity for work due to health reasons, as well as negligence

37 No. 262/2006 Col., http://www.mpsv.cz/files/clanky/3221/Labour_Code_2012.pdf, (accessed: September 2017). 
on the part of the employee affecting the way in which work is performed. Reaching a certain age is not, however, a valid reason for termination of the employment contract. ${ }^{38}$ Dismissal is also not justified by the acquisition of pension rights. It should be noted that under Czech legislation, the condition for acquiring a pension is not only reaching a certain age (the retirement age), but also having the required period of insurance, usually reduced to the period of employment. People can therefore continue to work even if they become entitled to a retirement pension at an earlier age. However, it must be stressed that a person who acquires pension rights may continue to work, collecting a salary in addition to the pension, but may also suspend the payment of the pension, which will positively impact its amount when taken. It should be also mentioned that the Labour Code includes situations where age is given as a reason for the ending (expiry) of a contract of employment. ${ }^{39}$ However, this applies only to certain occupations or professions where reaching a certain age is the basis for termination (expiry of employment). An example is the profession of prosecutor and judge. Employment shall then expire at the end of the calendar year in which people reach 70 years of age. It is also worth highlighting that in fact the voluntary redundancy schemes agreed by social partners can be applied to older workers who acquire pension rights. Persons who decide to accept termination of employment receive an appropriate compensation payment. Such solutions are widespread in the transport sector.

The Czech Labour Code also provides for a minimum notice period for the employment contract. For both parties, the employment relationship shall be at least two months and shall be independent of the period of employment of the person concerned. Therefore, regardless of the length of service, there is a common minimum statutory notice period for all employees. Some exceptions to this rule are provided for, but these do not apply to older workers. However, there is the possibility to extend the statutory notice period by agreement between the parties. Compensatory payments (rights) for termination of the employment contract by the employer are also provided for, depending on the duration of employment with the employer. Seniority is therefore a factor affecting the amount of monetary compensation. In addition, there is no obstacle to the minimum guaranteed payment being increased by collective agreement or agreement of the parties in the employment relationship.

It is important to highlight that amendments made to the Czech Labour Code since 2011,40 in particular in 2014, have made the majority of the provisions more

38 J. Pichrt, M. Stefko, Labor Law in the Czech Republic, [in:] R. Blanpain, F. Hendrickx (eds.), International Encyclopaedia of Laws/ Labour Law and Industrial Relations, 2 ed., The Netherlands 2015, p. 198.

39 Ibidem, pp. 213-214.

40 S. Clauwaert, S. and I. Schömann, The Crisis and National Labour Law Reforms: a Mapping Exercise, Country report: Czech Republic, last update: January 2013, https://www. etui.org/.../Czech+Republic+january+2013+WTC.pdf, (accessed: September 2017). 
flexible. ${ }^{41}$ Flexible forms of employment and work organisation, including parttime work, on-call duty, home -working, temporary work and employment under temporary employment contracts are regulated by the Czech Labour Code. ${ }^{42}$ As far as the agreement of fixed-term contracts of employment is concerned, there are certain restrictions on their maximum duration (and also on the number of renewals of such contracts), although these do not include the possibility of unlimited fixed-term employment contracts with people of retirement age or those acquiring pension rights. It is worth mentioning here that the obligation to conclude fixedterm employment contracts by persons who reach retirement age was waived under the 2008 Labour Code amendment. Therefore, the same principles apply to all employees, which obviously does not mean that certain solutions will not be applied more intensively to older persons. With regard to flexible working time, arrangements made by agreement between the parties to an employment relationship in the form of part-time or irregular working hours may be particularly useful for those reaching retirement age. The regulations for remote working (not on the employer's premises) are also worth noting.

To summ up it is worth highlighting that although the Czech Labour Code is lacking detailed solutions relating to older people, the provisions for persons with disabilities are also limited. ${ }^{43}$ Of course, regulation of health and safety conditions are a prerequisite for all workplaces. The employment of people with disabilities with specific related requirements, as well as allowances for employers reaching certain employment quotas, are regulated by the Employment Act. 44

Older employees, according to the Slovak Labour Code, have equal status with other employees. Special solutions are provided for those who take care for children up to 3 years, juveniles and people with disabilities. ${ }^{45}$ These concern, among other things, both a ban on termination of employment contracts 46 and a reduction in working hours. With regard to the working conditions laid down in the Labour Code, 47 the changes affecting older employees include a curtailment of overtime and night-time working. With respect to certain groups of older people over the age of 50 , such work may be carried out only with the consent of the employee. ${ }^{48}$

41 J. Pichrt, M. Stefko, Labour Law..., p. 95.

42 Ibidem, pp. 150-160, 177-181.

43 More information, ibidem, p. 222.

44 Ibidem.

45 H. Barancová, A. Olšovská, Labour Law in the Slovak Republic, 2 ed., The Netherlands 2014, pp. 108, 157-158.

46 It is important to note that the in some cases the validity of notice given by the employer is conditional on the previous consent of a state authority or employee representative. When comes to a person with reduced capacity the previous consent of the respective Labour Office is not required in case of the notice given to a handicapped employee over 65 years old, ibidem, p. 154.

47 More about changes in the Labour Code in recent years, see M. Kahancová, The Rise of the Dual Labour Market..., p. 14.

Art. 97 and 98 of the Labour Code. 
Moreover, measures have been provided for persons who are unable to continue work due to health problems, these are, among others, severance pay and providing them with an alternative post. ${ }^{49}$

The Slovak Labour Code contains regulations that can also be applied to older people. This applies in particular to flexible work organization, including the possibility of combining work and family responsibilities (job sharing) introduced as a result of the amendment of the Labour Code in 2011,50 as well as working from home, teleworking and part time work. The increase in part-time employment has especially occurred in recent years. In 2014, it amounted to 5.2\%. Restrictive measures were introduced in 2013 to reduce the signing of fixed-term contracts, according to which, fixed-term contracts can be implemented twice over a subsequent two-year period. In reality, however, this has not led to an increase in permanent employment. 51

The popularity in Slovakia of atypical bases of performing work (related to the performance of work outside of the framework of employment relationships) is worth noting. ${ }^{52}$ These are regulated by Articles 223-228a of the Labour Code, specifying the acceptable forms of work provision, including working hours. The work may be performed for no more than 350 hours per year, and in the case of occasional work it may be performed for no more than 10 hours per week. ${ }^{53}$ It should be stressed that the development and popularity of these forms of employment during the period under consideration was mainly due to the fact that there was no obligation to pay social security contributions. Employers had to pay slightly more than $1 \%$ of the remuneration for insurance: $0.8 \%$ on account of an accident at work and $0.25 \%$ to guarantee the maintenance the salary. They did not guarantee employees either employment nor insurance protection. Employment under these contracts also did not entitle the employee to a pension or other social security benefits. No sickness benefits, unemployment benefits nor paid annual leave were granted. ${ }^{54}$ Since 2013, employment contracts outside the employment relationship have been subject to contributions. As a result, this has led to a decrease in their number. ${ }^{55}$ The provisions of the Labour Code relating to working hours, minimum

49 Cf. H. Barancová, A. Olšovská, Labor Law in the Slovak Republic..., pp. 148, 164.

50 More on this M. Kahancová, M. Sedláková (Central European Labor Studies Institute, Eurofund), New Forms of Employment. Job Sharing and Casual Work, Slovakia, Case study 41: Policy analysis, pp. 2-3. Available at: https://www.eurofound.europa.eu/sites/default/files/page/field_ef_documents/41_-_ef1461_-_sk-job_sharing_and_casual_work_-_final.pdf, (accessed: September 2017).

51 M. Kahanec, M. Sedláková, Social and Employment Situation in Slovakia and Outlook of the Slovak EU Presidency 2016, May 2016, p. 21, available at: http://www.europarl. europa.eu/RegData/etudes/STUD/2016/578982/IPOL_STU(2016)578982_EN.pdf, p. 30, (accessed: September 2017).

52 More details H. Barancová, A. Olšovská, Labor Law in the Slovak..., pp. 92-94.

53 M. Kahancová, M. Sedláková, New Forms of Employment..., pp. 4-5.

54 An exception is made for instances where contributions were paid voluntarily. Ibidem.

55 M. Kahanec, M. Sedláková, Social and Employment..., p. 19. 
remuneration and employment protection also apply. ${ }^{56}$ However, these agreements continue to have a shorter notice period and no obligation for the employer to pay severance payments. ${ }^{57}$

Further Slovak Labour Code provisions that could apply particularly to older individuals remaining in employment include longer notice periods (from one to three months depending on seniority), and the right to severance pay as a result of dismissal. Also mention should be made of severance pay for people who terminate their employment in connection with the acquisition of the right to an old-age pension, an early retirement pension or a disability pension. Notice periods have changed since 2013. The minimum notice period is currently one month, although other periods of notice are considered in the case of economic redundancies and in the event of a deterioration in the health of the employee. In the case of employment over a year but less than 5 years there is a two-month period, whereas for persons with at least five years of service, the term of notice is three months. ${ }^{58}$

In addition, in Slovak Republic older workers have the same rights as other employees in the area of improving qualifications and training. Employers are obliged under the provisions of the Labour Code to enable employees to improve their qualifications. Interestingly, for those without a required professional qualification, employers are obliged to organize vocational training as a result of which the employee receives the appropriate certification. In addition, the obligation to organize retraining of employees covered those employers who transfer employees to new jobs or introduce novel work practices, if justified by these changes or other rational premises (Article 154 of the Labour Code). The obligation to raise and supplement the qualifications necessary to perform the contracted work is also provided for employees. It is therefore concluded that the support for vocational training, as well as for the completion and upskilling of professional qualifications during employment are key from the point of view of both sides of the employment relationship. 59

In the Netherlands the Civil Code is a particular source of regulating issues related to individual employment relationships. ${ }^{60}$ As far as the basics of employment provisions are concerned, flexible forms of employment include part-time work, fixed-term work, on-call service, temporary work and home-based work. 61 Although all of these forms may be used to employ older people, there are no specific regulations that would apply specifically to the age group indicated. Significant

56 H. Barancová, A. Olšovská, Labor Law in the Slovak.., p. 93.

57 Ibidem.

58 ENCC, European Monitoring Centre on Change, Slovakia: Notice Period for Employees, available at: https://www.eurofound.europa.eu/observatories/emcc/erm/legislation/ slovakia-notice-period-to-employees (accessed: 6.07.2017).

59 UNECE, National Report..., p. 8.

60 See comments on changes and scope of provisions of civil code A. T. J. M. Jacobs, Labor Law in the Netherlands..., pp. 63-65.

61 R. van het Kaar, F. Tros, The Netherlands: The role of governments..., p. 7. 
changes were made in the area of fixed-term employment contracts in 2014, with the aim of strengthening the positions of those employed on temporary contracts. Particularly noteworthy are the limitations on the number of consecutive contracts to three; and the maximum period for which fixed-term contracts may be agreed (decrease from 36 months to 24). Moreover, the 'interruption period' for the sequence of fixed-term contracts is up from three to six months. In addition, the employer is obliged to inform the employee of his intention to extend the contract at the latest one month before the end of the contract period. It is stressed that this could lead, on the one hand, to the increased role of indefinite contracts, and on the other to a positive impact on the position of fixed-term employees. ${ }^{62}$ Derogations in peius are, however, permissible in collective agreements. ${ }^{63}$ There are also regulations applied on the basis of collective agreements that introduce longer annual leave, however, these privileges are being phased out due to the prohibition on age discrimination. ${ }^{64}$

As regards the protection of the sustainability of the employment relationship in the Netherlands, the Civil Code provisions on the dismissal procedure deserve special attention. As a result of the reform of the law of 2014 on redundancies, a catalogue of the reasons for terminating an indefinite employment contract was introduced. The condition for the employer to give notice is that there is a true justification for such an act and there is no possibility of transfer to another post. ${ }^{65}$ The Dutch Civil Code also establishes protection for the sustainability of employment of certain categories of workers. Among the indicated categories there is no clear indication of older people. However, it should be added that the exclusions from the scope of unacceptable exemptions mention cases of terminating the employment contract due to reaching retirement age. ${ }^{66}$ The control system for the termination of employment contract is definitely unique. An employer intending to terminate the contract should obtain the consent of the relevant authority or by a court (ex ante control). The consent of the appropriate authority is required in the event of dismissal for economic reasons or as a result of the employee's inability to work after two years of illness. However, the above limitations do not apply when terminating a contract on the basis of agreement of the parties (referred to in the literature as an example of involuntary unemployment), ${ }^{67}$ in the event of the termination of the contract during the trial period, immediate dismissal or reaching retirement age. ${ }^{68}$ The second type of control which

62 N. Gundt, The Protection of Unemployed..., p. 18.

63 A. T. J. M. Jacobs, Labor Law in the Netherlands..., p. 196.

64 Ibidem, p. 134

65 The employer may terminate the employment contract on the day following the date on which the employee reaches retirement age ibidem, pp. 171-172.

66 Ibidem, pp. 171-172.

67 Ibidem, p. 174.

68 Exemptions also apply to groups of employees, including employees working in households. 
is applicable to employees exempted from the scope of ex ante control, entails the possibility of imposing an obligation to reinstate the employee by a court decision (ex post control). 69

The Dutch Civil Code also provides for the obligation of the employer to pay a 'transition allowance' in cases of the dismissal of employees that had been employed for at least two years, including, inter alia, in the case of termination of the employment contract by the employer and in the case of cancellation of the contract by a court. This benefit is not paid in cases of the termination of employment contracts due to, among other reasons, reaching retirement age entitling the employee to a pension. By 2020, people aged 50 and over with at least 10 years of service shall be paid at least $50 \%$ of their monthly salary for each half year of service. However, this is not applicable to employers employing less than 25 employees. It is important that the amount of the benefit due is of a minimum nature. Therefore, the entitlements mentioned above may be better agreed through collective agreements. Collective agreements may also waive these statutory safeguards, provided that adequate measures are put in place to counteract unemployment or shorten the unemployment period. ${ }^{70}$

The selection criteria for collective redundancies, which are regulated by the 1976 Dutch Act on Collective Redundancies, in particular, the so-called lifo rule (last-in-first-out) were applied, which meant that in companies affected by these redundancies, it was mostly the younger employees that were dismissed. In response to this, since 2006, the principle of proportionality has been applied. As a result of which the number of people selected for dismissal in each age category is determined. This solution is criticised for the increase in older people's dismissals, giving rise to the question of legitimate age differentiation. ${ }^{71}$

The Dutch regulations relating to the automatic termination of employment also deserve attention. This is done on the basis of the relevant provisions of collective agreements or individual employment contracts. It is generally accepted that an indefinite term contract is automatically terminated when the retirement age is reached. Studies have shown that over $70 \%$ of employees are covered by collective agreements containing such clauses. In view of the objections from people wishing to continue working despite reaching the retirement age in 2008-2012, a number of court rulings were issued which refused to accept the automatic termination of the said employment contract. However, in one of the more recent rulings, the Supreme Court held that retirement age as a condition for the automatic termination of employment contracts may be indicated in collective agreements. Doubts were caused in relation to a retirement age lower than the general one. In such cases a need for additional objective reasons to justify it were highlighted. ${ }^{72}$

69 A. T. J. M. Jacobs, Labor Law in the Netherlands..., pp. 176-182.

70 Ibidem, p. 185.

71 Ibidem, p. 189-190.

72 Ibidem, p. 197. 
Reference should also be made to the Dutch Act on Dismissals. Recent amendments to the Act were intended to make dismissals easier and less costly. The relevant authorities and the district judge not only consider the dismissal, but also determine whether there is a real possibility of finding the employee another position within the company, especially after training. If this is possible, consent to dismiss is not granted. Emphasis has been placed on measures to assist the transfer of employees from work to work. The transition allowance referred to above should be used to mitigate the effect of transferring to another job, e.g. by paying for training. The 2015 Act, in this respect, puts a strong emphasis on tackling long-term unemployment, by urging the transfer of workers to other jobs. ${ }^{73}$

\subsection{Prohibition of discrimination on the grounds of age}

As far as the prohibition of discrimination is concerned, the provisions of the Lithuanian Labor Code which prohibit discrimination are particularly worth highlighting. Importantly, these criteria include age without specifying whether it is applied to the young or old. Pursuant to the Lithuanian Law on Equal Treatment of 18 November $2003,{ }^{74}$ any direct or indirect discrimination based upon age shall be prohibited. The legislator does not indicate specifically, however, old age. The term Age designates the general category of discrimination of employees which is prohibited. The Law has a wide scope of application, going beyond the employment relationship issue. Article 5 of the law concerned lays down the obligations of the employer in the exercise of equal rights at work. To this end, the employer shall apply the same conditions for e.g. recruitment, dismissal, training, upgrading, regardless of age. Violation of the principle of equal rights is considered to have occurred where, due to age, less (more) favorable employment criteria are used, where the same or similar work receives different remuneration, when less (more) favorable opportunities for retraining to increase qualifications are created and also when sanctions are imposed, working conditions changed, an employee is transferred to another post or dismissed (Article 7 of the law concerned). Job offers which create a bias in employment in favour of persons of a certain age are also considered discriminatory (Article 10 of the Law). The above deserves a particularly positive reference, as the study found that half of the respondents indicated that job offers were the main factors excluding older people from being potential applicants. ${ }^{75} \mathrm{~A}$ person who believes

73 N. Gundt, The Protection of Unemployed..., p. 19.

74 Lietuvos Respublikos lygių galimybių istatymas 2003 m. Lapkričio 18 d., No. Ix-1826,http://www3.Irs.It/pls/inter3/dokpaieska.showdoc_l?p_id=454179, (accessed: January 2016).

75 R. Brazienè, I. Mikutavičienè, A. Dorelaitienè, U. Žalkauskaitė, J. Jurkevičienè, Vyresnio amžiaus žmoniu (socialinès įtraukites) i(si)traukimo i darbo rinka galimybių atsakaita, 2014 m., www.lygybe.lt (accessed: January 2016). 
that they have been discriminated against has the right to appeal to the Equal Opportunities Ombudsman.

A comprehensive study on discrimination, including discrimination on the grounds of age, was conducted in Lithuania in 2008, and its results were included in a research report on infringements of equal rights. ${ }^{76}$ It indicates that older workers are more frequently discriminated against when compared to their younger counterparts. In this respect, discrimination is manifested, among others, by a refusal of employment, lower wages and redundancies without justified reasons. The negative attitude of society to the older as frail, with health problems and difficulty in adapting to new work environments is also mentioned as being among the main causes of discrimination. However, it has been noted that the number of complaints regarding discrimination on the grounds of age is decreasing year by year.

The Czech legislation distinguishes three main legal acts dealing with the issue of the prohibition of discrimination. Age (as well as gender, ethnicity and religion) is one of the prohibited criteria. The law on Employment of May 13 ${ }^{\text {th }}, 2004^{77}$ also prohibits discrimination in the recruitment procedure. It imposes on labour offices an obligation of equal treatment; as regards access to employment, preparation for work, training and other assistance measures. The Czech Labour Code ${ }^{78}$ lays down only a general prohibition of discrimination in employment. It requires the employer to treat employees equally in terms of working conditions, pay, access to training and professional development. However, differences in treatment shall not be considered as discrimination if they are linked to an essential professional requirement necessary for the performance of the role. There are no specific provisions in the Czech Labour Code as regards specific forms of discrimination, definitions and protection measures, however these were provided for in the AntiDiscrimination Act of April 23rd, 2008,79 to which the Labour Code refers directly. The Anti-Discrimination Act has a wide scope of application. Its provisions apply to broadly defined employment, covering not only the provision of work under an employment contract, but also to the freedom to conduct economic activity, self-employment; access to health care, education, membership of professional organizations and other services (section 1 of the Act). The abovementioned Act also refers to a permitted differentiation of treatment on the grounds of age as regards access to employment where a minimum age, professional experience or length of service is required for the post, occupation or access to a particular job or

76 G. Navaitis, A. Burneikienè, R. Trinkūnienè, Lygių galimybių pažeidimai (amžiaus aspektas), Socialinis Darbas 2008, no. 7 (3), pp. 41-47, https://www.mruni.eu/upload/ iblock/5b7 /5_navaitis_burneikiene_trinkuniene.pdf, (accessed: January 2016). See also general remarks on anti-discrimination legislation included in the report prepared by experts on behalf of the European Commission: Age and Employment, as of July 2011, available at https: //www.age_and_employmen_en.pdf, (accessed: September 2017). Act No. 435/2004 Coll.

78 Act No. 262/2006 Coll.

79 Act No. 198/2009 Coll. 
the job's obligations, as well as access to the vocational training necessary to improve performance, if, taking into account the duration of the training, the person seeking a job enters retirement age, as defined in the separate provisions. In accordance with the Act, the disparity between the retirement ages for women and men along with any difference in treatment on the grounds of age when objectively justified by a legitimate aim and the measures taken to achieve it are appropriate, do not constitute discrimination. Age is included in the form of a general criterion, which means that it covers both the old and young. Provisions specifying the prohibition of discrimination on the grounds of gender (section 8 of Law) contain reference to advanced age. Any person who has suffered discrimination is entitled to seek compensation, which is determined by the court on a case-by-case basis, since neither a minimum nor a maximum limit has been set. Moreover, the person discriminated against may seek financial compensation for the harm suffered (section 10 of the Act). ${ }^{80} \mathrm{~A}$ similar solution is provided for in the Employment Act. However, the maximum penalty here may not exceed $€ 40000$.

The Czech National Labour Inspectorate may impose penalties of a similar amount for acts of discrimination in accordance with the Labour Inspection Act of 3 May $2005^{81}$. Basic institutional support for counteracting discrimination, taking into account the scope of the activities of relevant institutions, is granted by the Ministry of Labour and Social Policy (MoLSA), Labour Inspectorates and labour offices. In addition, employees whose rights of equal treatment have been breached have the right to appeal to the State Rights Defenders (Ombudsman).

While it must be said that claims in the Czech Republic based on discrimination are rare, the main reasons for this include the length and cost of court proceedings. Recent cases have included age discrimination cases in recruitment procedures and termination of the employment contracts of older people in connection with restructuring. The Czech Constitutional Court has taken a stand on the latter case. It considered that the practice of dismissing older workers as a result of the restructuring process during which younger workers were then employed was discriminatory. In the court's view, the fact that the exemptions were made within the legal constraints and were objectively justified were irrelevant. The position expressed by the Constitutional Tribunal was based on statistical data. They showed that $80 \%$ of workers made redundant were over 50 years of age, while $93 \%$ of those hired were under $28 .{ }^{82}$ The literature also points out that in fact the discrimination on the grounds of advanced age is not a rare case. This is confirmed by research, supported by interviews also with employers. They emphasize that among groups at risk - such as young people, those starting families, women after

80 Disputes based on discrimination are dealt with by ordinary courts. There are no separate labour courts in the Czech Republic.

81 Act. No. 251/2005 Coll.

82 See: http://www.agediscrimination.info/international-age-discrimination/czech-republic, (accessed: September 2017). 
maternity leave and persons of retirement age and pensioners - older people are valued lowest. 83

As far as anti-discrimination solutions are concerned, in Slovakia they are in line with those existing in other countries of the European Union. The main problem in combating discrimination is, however, that of proving it; since it occurs primarily in hidden forms. ${ }^{84}$ Particular attention should be paid to the Slovak Act on Equal Treatment and Protection against Discrimination, ${ }^{85}$ which prohibits discrimination on the grounds of the criteria listed therein, including age and disability. This is especially true of employers' obligations to integrate people with disabilities in the working environment. 86 This ban covers broadly understood employment relations and other areas of legal relations. ${ }^{87}$ However, it should be stressed that the using of prohibited (discriminatory) criteria are also laid down in the Employment Services Act and the Labour Code. The Labour Code provisions show that considerable efforts have been made to combat unfair treatment on the grounds of gender. Its' Article 6 states that men and women must be treated equally in terms of access to work, remuneration, vocational training and working conditions. It is also important to place those with childcare duties and parental responsibilities in the categories of persons in particularly unfavourable situation on the labour market. A strong emphasis of the prohibition of discrimination based on the grounds of gender is also evident in the provisions of the Employment Services Act, which clearly emphasizes equal treatment of persons regardless of gender, in the scope of the provision of labour market services. 88

As regards surveys conducted among older persons, more than half of Slovak respondents in the 50-64 age group indicated unequal treatment and discrimination in the labour market. It was noted that these practices, take place, in particular, during the recruitment and dismissal procedures. Employers stress that the so-called 'unattractiveness' of older persons in the labour market increases incrementally with age. However, studies have shown that, in addition to age, the most common reason for discrimination in the labour market is disability. More than $70 \%$ of respondents considered it to be a serious employment problem. It is important to note that the results of the research showed that both the majority of respondents aged 50-64 (71\%) and representatives of employers (76\%) stressed that older people have qualifications which can be successfully used in newly created workplaces. 89

83 L. Vidovićová, Conceptual Framework of the Active Ageing Policies in Employment in Czech Republic CASE Research Paper No. 469/2014, p. 11, https://papers.ssrn.com/sol3/ papers.cfm?abstract_id=2406880, (accessed: September 2017).

L. Vagač, EEO Review: Employment Policies..., p. 9.

85 Act No 365/2004, as amended.

86 H. Barancová, A. Olšovská, Labor Law in the Slovak..., pp. 110-111.

87 Ibidem, p. 106.

88 L. Vagač, EEO Review: Employment Policies..., pp. 5, 9.

89 M. Kordošová (Institute for Labour and Family Research), Unfair Treatment of Older People in the Labour Market, Ageing Workforce, available at: https://www.eurofound. 
In the Netherlands in the field of age discrimination, surveys have shown that employers perceive the employability of older workers stereotypically. Especially when it comes to physical health, creativity and competence in new technologies. Consequently, employers prefer to employ younger people. Even qualities such as loyalty, trust, organizational skills that distinguish older workers appear to be less important for employers. ${ }^{90}$ Although the Equal Treatment Act of 1992 (GAET) deserves attention in this respect, more attention should be paid to the $2003 \mathrm{Law}$ on Equal Treatment on the Grounds of Age at Work, Occupation and Vocational Training (AETAW). According to which, the ban on age discrimination does not apply to cases of age discrimination in relation to the implementation of statutory policies in order to increase the participation of people in specific age groups. In addition, this applies to cases of termination of employment contracts in connection with reaching retirement age, and also if the difference in treatment on the grounds of age is objectively justified and measures to achieve the intended objective are necessary and appropriate (legislation on occupational pensions may also be a reason for the differences in treatment on the grounds of age). As has already been noted, some doubts concerning the legality of the regulations are raised by cases over the more favourable shaping of working conditions (e. g. in the scope of longer leave, shorter working time standards) of the older person. Courts do not prohibit the use of such practices, but require them to be applied under certain conditions. It is about the proportionality and necessity of the differentiating measures adopted, especially where these are part of human resources management policies. Difficulties in demonstrating the proportionality and necessity of the adopted differences have resulted in the majority of such clauses being repealed from collective agreements. However, the use of working schedules suitable for older workers has increased, now being used more often than ever before. ${ }^{91}$

\subsection{Active and passive legal measures related to combating unemployment among older people}

Public employment services in Lithuania provide jobseekers with assistance in finding work, encourage registered unemployed persons to either participate in employment programmes, take part in vocational training and retraining, start their own business, participate in public works or job creation ("intervention") schemes. They also help employers to find appropriately qualified workers, support entrepreneurs (employers) in creating new jobs and pay unemployment benefits. The main

europa.eu/observatories/eurwork/articles/unfair-treatment-of-older-people-in-the-labour-market (accessed: 22.04.2014).

90 R. van het Kaar, F. Tros, The Netherlands: The Role of Governments..., p. 3.

91 A. T. J. M. Jacobs, Labour Law in the Netherlands..., pp. 89, 97-98. 
Lithuanian Public Employment Service operates under the supervision of the Ministry of Social Security and Labour. It should be emphasized that, after restructuring, a new network of regional offices was introduced on October $1^{\text {st }}, 2010$. The previous model, consisting of 46 offices, was replaced by more customer-oriented local labour offices. Currently, in addition to the Lithuanian Labour Exchange (Lietuvos Darbo Birža) there are 10 local labour offices, situated in the largest Lithuanian cities. ${ }^{92}$

The Lithuanian Law on Support for Employment of 15 June $2006^{93}$ distinguishes several categories of being unemployed. It states that the term unemployed denotes a working-age person who is neither in employment, in vocational training, nor studying and is registered at a regional labour office. The concept of a person of working age is to be understood as persons over 16 years of age who have not reached the retirement age as defined in the law on support for employment. The definition of an unemployed person is contained in paragraph 13 of the aforementioned Article. In accordance with Article 4 of the above law, additional support on the labour market covers persons of working age older than 50 , provided that they are able to work. However, the above terms contain no reference to these persons as being unemployed within the meaning of the Act. It should also be noted that under the aforementioned law the legislator also uses the concept of persons who are no more than 5 years from reaching retirement age. The law distinguishes between employment support measures and labour market services. The same measures are applied to various target groups. However, due to the fact that persons over 50 are included in the category of those that require additional support within the meaning of Article 4 (1) point 7 of the law on support for employment, either additional funding in connection with the application of professional activation measures, or an extended period of receipt of benefits intended for particularly vulnerable groups on the labour market are provided. It should be added that among the groups supported on the labour market, those who had remained unemployed for at least 2 years after registering at the labour office were also mentioned (Article 4 (1) point 10 of the law ${ }^{94}$ ).

Subsidized employment is targeted according to Lithuanian legislation at those who are covered by additional labour market support, including those over 50 and able to work (point 38.7 of the order on the rules and procedures for the implementation of active labour market policy measures ${ }^{95}$ ). Support for

92 Ministerstwo Rodziny, Pracy i Polityki Społecznej - Departament Rynku Pracy, Warunki życia i pracy w krajach Europejskiego Obszaru Gospodarczego, Litwa, www.eures.praca. gov.pl/zal/warunki_zycia/litwa/litwa.pdf, (accessed: January 2016).

93 Lietuvos Respublikos užimtumo rèmimo istatymas, 2006 m. birželio 15 d., nr. x-694, http://www3.Irs.lt/pls/inter3/dokpaieska.showdoc_l?p_id=478633, (accessed: January 2016). Law on Support for Employment (Užimtumo rémimo istatymas) of 14 July 2009 (No. XI-334).

94 Hereinafter referred to as l.o.e.

95 Lietuvos Respublikos Socialinès Apsaugos ir Darbo Ministro įsakymas Dèl aktyvios darbo rinkos politikos priemoniu igyvendinimo sąlygų ir tvarkos aprašo patvirtinimo 
the above persons is based on funding amounting to $50 \%$ of the expenditure cost incurred in relation to their employment for a period of not longer than 6 months. As a comparison, it should be emphasized that in the case of persons with disabilities, the funding amounts to $75 \%$ of the expenditure (point 39 of the order). On the other hand, with regard to the acquisition of professional qualifications and subsidizing salaries, older persons are not explicitly mentioned as a target group. Those who are long-term unemployed or who have been unemployed for more than two years prior to registration at the employment office are the prioritised recipients of assistance (point 47 of the order). Temporary replacement in employment is also one of the elements supporting the return to employment. In this situation, those sent by labour offices are employed to cover for workers granted leave, including that in collective agreements. Subsidies granted to employers include funding salaries and the partial financing of compulsory social insurance contributions, provided that the amount does not exceed twice the minimum remuneration in the case of the employment of persons benefiting from additional support on the labour market (including those over 50) and covers $70-75 \%$ of calculated expenditures.

Support for the movement between regions of the unemployed is also noteworthy. This is regulated by provisions of Article 33 of the aforementioned Lithuanian law, according to which, this employment policy measure is used to promote employment away from the area of residence, when the responsible labour office cannot provide a suitable job. The unemployed working away from their place of residence have their commuting costs to the workplace and associated accommodation costs financed for a period of not longer than 3 months. The monthly amount may not exceed $0.5 \%$ of the minimum wage approved by the Government of the Republic of Lithuania. However, the condition for the granting of financing is that the monthly travel costs exceed $20 \%$ of the remuneration received by the employee, provided that the remuneration received is less than the sum of two minimum salaries. Accommodation expenses shall be reimbursed, as long as the commute to the place of work does not take place more than once a week. At this point, the profiling of the types of assistance for the unemployed and the setting up of individual employment programs are also worth emphasizing. In general, however, the above are applicable to people with little professional experience or to graduates. The preferential treatment of the above categories of unemployed persons is confirmed by regulations imposing on those entities obliged to set up individualised support programs the necessity to take action as soon as possible. For example, individualised employment plans are established within one month for people under 29, whereas for people over 29 it is within three months of registration at the labour office.

2009 m. rugpjūčio 13 d., Nr. A1-499, http://www3.Irs.lt/pls/inter3/dokpaieska. showdoc_l?p_id=350927\&p_query=\&p_tr2, (accessed: January 2016). 
It should be noted that the Lithuanian law of June 30, 1998 on Informal Learning and Continuing Education by the older person ${ }^{96}$ constitutes a legal solution of particular importance. It addresses the important legal issues that underpin the projects carried out on this basis and is focused on older people with the objective of encouraging lifelong learning. The development of a database of older people interested in finding a job is also worth noting. It entails putting the data of these people into the so-called Senior's Bank. The aim of which is to help with job searches by persons in older age (above 50) and persons of retirement age. People interested in getting a job register electronically on the website of the relevant office and fill out an appropriate form, before waiting for responses from employers who are interested in hiring persons at pre-retirement age (or even post retirement age).

Unemployment benefits under the Lithuanian Law on Support for Employment of 15 June 2006 is granted to an unemployed person within the meaning of Article 2 (3). In turn, the detailed conditions of granting the benefit are determined by the Act of 16 December 2003 on unemployment insurance. ${ }^{97}$ According to Article 5 of this Act, the right to unemployment benefit is granted to insured, out of work persons (in accordance with Article 4 of the aforementioned law) who are registered in the local labour office, have not been offered an appropriate job or any other active labour market measures from the said office, and whose unemployment insurance contributions were paid prior to registration at the labour office for at least 18 months out of the previous 36. In accordance with Article 7 of the aforementioned Act, unemployment benefit is dependent on the number of years in which contributions were paid before registration at the labour office. If contributions have been paid for less than 25 years, the allowance shall be paid for 6 months, from 25 to 30 years, the allowance shall be paid for 7 months, from 30-35 years, the allowance shall be paid for 8 months, for more than 35 years, the allowance shall be paid for 9 months.

It should be emphasized that on the basis of Article 14 of the above Lithuanian law, the possibility of extending the period of unemployment benefit was introduced. If the applicant has a maximum of 5 years left until retirement age, payment of the unemployment benefit shall be extended for a further 2 months. The duration of payment of unemployment benefit in municipalities with the highest registered unemployment rate can be extended by 2 months. In the case of incapacity for work, the duration of payment is prolonged for as many calendar days as the jobseeker is incapacitated, up to 30 days. It is important that from 1 July 2017, the duration of unemployment insurance benefit will no longer be linked to the unemployment insurance period but will be paid for 6 months for all unemployed who meet

96 Lietuvos respublikos neformaliojo suaugusiųjų švietimo įstatymo, No. VIII-822. Recently amended by Law No. viii-822 pakeitimo istatymas 2014 m. liepos 10 d. No. XII-1018.

97 Nedarbo socialinio draudimo istatymas of 16 December 2003 (No. IX-1904). Valstybinio socialinio draudimo istatymas of 21 May 1991 (No. I-1336). 
the necessary conditions. Additionally, from this date the duration of payment of the benefit in municipalities with the highest registered unemployment rate will no longer be extended, but the duration of payment will be extended to the unemployed who are voluntarily undergoing treatment for alcoholism, drug or toxic substance abuse in specialised hospitals for up to 14 days a year. 98

In the Lithuania before 1 July 2017 there were no special provisions related to partial unemployment. From 1 July 2017, those having to work part time because of the severe economic difficulties faced by the employer (the employer can reduce working hours up to a maximum of 50\%) will be paid a part-time benefit. The part-time benefit will be paid for 3 months and will be calculated as the unemployment insurance benefit on a pro rata basis in proportion to the reduced working hours. ${ }^{99}$ The unemployment benefit consists of a fixed and a variable part. 100 For the first 3 months, the unemployed person receives the full amount of the benefit, for the remaining period - the fixed part and $50 \%$ of the variable part. It is important to note that from 1 July 2017, the fixed part of the benefit will be $30 \%$ of the minimum monthly wage, while the variable part is linked to the country's average wage and to income which was received prior to registration with the local labour exchange. The average monthly insured income of the unemployed will be calculated as an average income of the 24 months prior to registration with the local labour exchange. The variable part in the first 2 month will be $50 \%$ of the average monthly insured income of the unemployed; $40 \%$ in the $3^{\text {rd }}$ and $4^{\text {th }}$ month and $30 \%$ in the $5^{\text {th }}$ and $6^{\text {th }}$ month. Moreover, the unemployment benefit cannot be less than $30 \%$ of the minimum monthly wage, but cannot exceed $75 \%$ of the average national wage. ${ }^{101}$

Taking into account the legal measures addressed to unemployed persons (jobseekers) in the Czech Republic, the Law on Employment should be taken into account. ${ }^{102}$ Active labour market instruments are addressed in particular to those

98 Law on Employment (Užimtumo jstatymas) of 21 June 2016 (No. XII-2470). Will come into force on 1 July 2017 and replace the Law on Support for Employment.

99 MISSOC Information Base, Comparative Tables on Social Protection, Unemployment: Lithuania, available at: http://www.missoc.org/MISSOC/INFORMATIONBASE/COMPARATIVETABLES/MISSOCDATABASE/comparativeTablesSearchResultTree.jsp. (accessed: 1.01.2017).

100 The fixed part is the amount of income eligible for social assistance in a given month. The variable part is calculated as follows:

1) to begin with, the monthly insured income of the unemployed person for the 36 months prior to the end of the last quarter before registering at the labor office is calculated,

2) the average ratio of that insured income in a given month is determined,

3) this ratio is multiplied by the insured income in the month in which the allowance is to be paid,

4) the variable part of the allowance is $40 \%$ of the amount from point 3.

101 Ibidem.

102 Act No 435/2004, Employment Act (Zákon o zaměstnanosti). 
who are classified as being in specific situation on the labour market. ${ }^{103}$ From 2006, individual programmes have been prepared for people over 50 years old. Moreover, professional retraining and councelling programmes are applied to those who have been unemployed for over 6 months. Financial benefits and subsidies may be provided to employers employing older and disabled employees. Older people who take up self-employment or start work as employees also enjoy financial support.104 The length of the payment of unemployment benefit depends on the age of the unemployed person. People between the ages of 50 and 55 are entitled to unemployment benefit for a period of 8 months, for people above that age this period has been extended to 11 months, ${ }^{105}$ while up to the age of 50 years the unemployment benefit is paid for 5 months. The unemployment allowance is dependent on the last received earnings. In the case of retraining the unemployment benefit is paid during the whole period of retraining. The determining factors for unemployment benefit are as the following: previous earnings, duration of unemployment, nature of unemployment (voluntary or involuntary). For the first two months: $65 \%$ of reference earnings, the following two months: $50 \%$ of reference earnings, and $45 \%$ of reference earnings for the rest of the period of support. During retraining entitled people get $60 \%$ of reference earnings. If the last employment is terminated by notice of termination given by the employee or by agreement, and is without valid reason, the rate of the unemployment benefit shall be set at $45 \%$ for the entire period of support.

When it comes to Slovakia, as it was highlighted in literature, there are no significant and meaningful measures aimed at active ageing in the period prior to 2010.106 Hence, starting from 2011, the development of a national strategy on active ageing has become the main task in line with the policies of the European Union. 107 The main areas for additional action have also been identified, these included above all the Lifelong Learning policy. 108 The activity of the older population in education and vocational training was very low (about $0.8 \%$ ), which

103 For more see M. Halásková, R. Halásková, M. Slavata, Concept of Flexicurity in the Conditions of Labour Market of the Czech Republic, [in:] K. Lordoğlu, D. Keskin Demirer, i. Şiriner (eds.), Labour Markets and Employment, London 2012, available at: https:// books.google.pl/books?id=WN0nMB6_3_gC\&pg=PA149\&lpg=PA149\&dq=disadvanta ged+groups+in+CZech+labour+market\&source=bl\&ots=7kSIJPK4bh\&sig=vgNGibQe tpwrjD_d8jTBp26p_i8\&hl=pl\&sa=X\&ved=0ahUKEwjxr_HwpszVAhUGKIAKHTG5DIEQ6 AEIQDAD\#v=onepage\&q=disadvantaged\%20groups\%20in\%20CZech\%20labour\%20 market\&f=false, (accessed: September 2017).

104 OECD thematic follow-up for review of policies to improve labour market prospects for older workers, Czech Republic (situation mid-2012), p. 4-5, available at: https://www. oecd.org/els/emp/Older\%20Workers\%20Czech\%20Republic-MOD.pdf, (accessed: September 2017)..

105 Act No. 435/2004, Employment Act (Zákon o zaměstnanosti).

106 L. Vagač, European Employment Observatory, EEO Review..., p. 5.

107 Announcement of the 2012 as the European Year for Active Ageing and Intergenerational Solidarity.

108 L. Vagač, European Employment Observatory, EEO Review..., p. 5. 
in fact was reflected in the early exit from the labour market by persons in the examined age group. Lack of appropriate Lifelong Learning policy was recognized as the most important challenge for Slovak society. Despite the establishment of the Institute for Lifelong Learning in 2010, and the adoption of a normative act on the same subject, ${ }^{109}$ only $3 \%$ of adults of working age participated in the programme (compared to $10.7 \%$ across the $\mathrm{EU}$ ). ${ }^{110} \mathrm{In}$ addition, the role of promoting healthy and safe working conditions and promoting a well-being policy at work have also been recognized. 111

In December 2013, the Government of the Slovak Republic adopted the National Programme for Active Ageing 2014-2020. The aim of which was to take a comprehensive look at the issue of the ageing society and to make it a priority from a political aspect. In addition, a study has been conducted on factors influencing the participation of older people in the labour market. This was carried out under the National Strategy for Active Ageing, financed by the European Social Fund. Studies have shown that people aged 50-64 are not just a vulnerable group in the labour market, but in fact they are at a particularly high risk. ${ }^{112}$ According to the obtained information, active labour market measures include inter alia: employment mediation, information and advice services, specialised advice services, which include preparation in cooperation with the disadvantaged jobseeker ${ }^{113}$ (at the invitation of the office or at the written request of the disadvantaged jobseeker) of an individual action plan. An individual action plan is prepared in order to improve the jobseeker's prospects in the labour market. Under Section 49a of the act on Employment Services, ${ }^{114}$ an employer may provide performance training of the required work activities for a disadvantaged jobseeker before the start of employment. The purpose of this is the acquisition of the practical experience and working habits necessary to perform the duties required by the potential employer. Under Section 50, an employment allowance to support disadvantaged jobseeker is provided to an employer (for a person who has been a registered jobseeker for at least three months) in a newly created job, while section 50i of the abovementioned law regulates an allowance to support regional and local employment and is provided to an employer who employs, for a set period, a disadvantaged jobseeker if employment for a fixed term is agreed for at least nine months and for at least a half of the employer's set weekly working hours. Support for the integration of disadvantaged job seekers is provided in accordance with Section $53 \mathrm{c}$ of the act on employment services

109 Act No. 568/2009.

110 European Commission (2015), Education and Training Monitor 2015: Slovakia, available at: http://ec.europa.eu/education/toools/docs/2015/monitor2015-slovakia_en.pdf, (accessed: September 2017).

111 L. Vagač, European Employment Observatory, EEO Review..., p. 6.

112 M. Kordošová, Unfair Treatment of Older People...

113 The abovementioned category includes among others the people over 50 years of age.

114 Law on Employment Services (Zákon o službách zamestnanosti) 2004, no. 5. 
and is intended to improve the prospects for finding and retaining a job for a period of at least six months. 115

Although Slovak legislation has recognized that people over 50 as particularly disadvantaged in the labour market, no specific measures have been provided exclusively for them. The designation of a person as particularly disadvantaged in the labour market entitles them to priority access to labour market services. ${ }^{116}$ However, the low effectiveness of active labour market policies measures for this age group is due to the fact that their specific older work-related requirements are not taken into account. 117

Due to continuing unacceptable unemployment levels among young people and those over 50, in 2012, the Government of the Slovak Republic introduced legislative measures to support job creation and job preservation. As regards older people, it was about creating jobs for those who were registered as unemployed for at least six months. By employing older people in full-time employment for a period of at least 18 months, employers would receive co-financing of the salaries. The co-financing was set at 95\% of the employment costs determined for 2013 (approximately 456 EUR) and it was to be paid over a period of 12 months. The employer was then obliged to maintain the job for a further 6 months. Another means of supporting employers was the possibility of obtaining subsidies to maintain employment levels in cases of economic difficulties. Government subsidies covered employee social security contributions for up to 60 days per year. A similar solution was introduced during the economic crisis in 2009-2011.118 In addition, changes have been made to the entitlement to unemployment benefits for their acquisition under fixed-term employment contracts. ${ }^{119}$

In the Slovak Republic the policies promoting the prolongation of professional activity by improving the quality of work, indicated the particular role of programmes emphasising the importance of training and lifelong learning. Education among older people - especially (as the main target group) of people over the age

115 UNECE, National Report, The Situation of Older People in Slovakia. Combating Poverty, pp. 7-8, available at: https://www.unece.org/fileadmin/DAM/pau/age/country_rpts/ SVK_report.pdf, (accessed: September 2017).

116 Disadvantaged persons are: young graduates up to the age of 26 or persons over the age of 50 , long-term unemployed, people with a poor education, disabled persons, single parents with at least 1 child until the completion of compulsory school age, etc. See MISSOC, Comparative Tables on Social Protection Results, Unemployment, Slovakia, available at: http://www.missoc.org/MISSOC/INFORMATIONBASE/COMPARATIVETABLES/ MISSOCDATABASE/comparativeTablesSearchResultTree.jsp, (accessed: September 2017).

117 L. Vagač, European Employment Observatory, EEO Review..., pp. 7-8

118 L. Crizia (Institute for Labour and Family Research), Governments Schemes Support Employment, available at: https://www.eurofound.europa.eu/observatories/eurwork/ articles/government-schemes-support-employment (accessed: 7.04.2013).

119 In this regard, there is a shorter contribution period of two years over a four-year period instead of the required three-year period. The period of collecting benefits for term contracts is 4 months (for contracts with no fixed term - 6 months). 
of 50 - within the framework of Third Age Universities (TAU) deserves special attention. There is a strong interest in this form of raising qualifications due to, among other things, the low costs of education within the TAU. ${ }^{120}$

Reforms carried out in Slovak Republic in 2014-2016 should also be mentioned. In 2015, in order to facilitate access to employment for low-skilled persons, a reduction in health insurance contribution rates for low-wage employees was introduced in order to reduce the costs of hiring employees and increasing their net salary. ${ }^{121}$ The above objective is also implemented through further solutions, including the increase in the minimum wage and tax solutions limiting employment of persons on the basis of atypical forms of employment. ${ }^{122}$ The actions of the Government of Slovakia, aimed at eliminating the segmentation of the labour market, also deserve attention. Legislation has been adopted guaranteeing equal treatment of people employed outside the framework of employment relationship, 123 along with initiatives to combine work and family responsibilities (especially when it comes to parental responsibilities) and major efforts have been made to increase the efficiency of public employment services. ${ }^{124}$

It is important to note that in Slovakia there are no specific provisions related to the granting of unemployment benefits to the older unemployed. ${ }^{125} \mathrm{The} \mathrm{du}$ ration of the payment of unemployment benefit depends on the basis of the employment contract. Unemployment benefits are paid for a period of 6 months or 4 months in the case of employees on fixed-term labour contracts. After a period of 3 months, the beneficiary has the choice either to continue receiving benefit (for another 3 months maximum) or to cancel the registration as jobseeker and obtain a bonus. ${ }^{126}$

In the Netherlands, according to a study carried out in 2013, among the main barriers to prolonging the working-age of older people, was their low participation older people in training and education. However, it was noted that the reason

120 L. Crizia (Institute for Labour and Family Research), Slovakia: The Role of the Governments and Social Partners in Keeping Older Workers in the Labour Market, available at: https://www.eurofound.europa.eu/observatories/eurwork/comparative-information/ role-of-governments-and-social-partners-in-keeping-older-workers-in-the-labour-market. (accessed: 2.06.2013).

121 Act No 580/2004 on Health Insurance, valid since January 2017.

122 M. Kahanec, M. Sedláková, Social and Employment..., p. 19.

123 Ibidem, p. 9.

124 Ibidem.

125 There is also the statement that the relatively high unemployment benefits reduces inequality and poverty, but provides lesser incentives to work, and does not stimulate active job searching. However, it is important to note that Slovakia has strict eligibility criteria for unemployment benefits, with the longest required period of insurance contributions prior to unemployment in the whole of the EU (at least two years of contributions in the last 3 years for a standard contract, 4 years for a fixed-term contract) see: M. Kahanec, M. Sedláková, Social and Employment..., p. 20.

126 MISSOC, Comparative Tables on Social Protection Results, Unemployment, Slovakia. 
for this is the lack of suitable programs to encourage older people to participate in training. Studies have shown that people with a higher education are characterized by much longer professional activity, ${ }^{127}$ and that pre-retirement benefits under the social security scheme are more often provided to older people who are employed under temporary contracts, as well as to people with greater seniority who work in conditions unfavourable to their professional career development. ${ }^{128}$ It has been noted that persons who work in flexible forms of employment are in a significantly weaker position on the job market. Among the reasons for low participation in employment by older people, low labour mobility capacity was also indicated. ${ }^{129}$ The Dutch Act on Unemployment Benefits ( $\mathrm{WW}^{130}$ ) deserves attention with regard to the legal measures that encourage people to work. In 2009, a norm was introduced according to which the long-term unemployed (for over 1 year) had to accept any job offer, even if it did not meet their expectations. The derogations of older workers in this respect have been abrogated. ${ }^{131}$ Also noteworthy is the continuation of the payment of benefits for a person taking up employment, as well as the so-called 'calamity benefit' (benefit paid to compensate for labour costs), which include, among others, the reduction of employees' working hours (this allowance is referred to as part-time unemployment benefit). ${ }^{132}$ It should be stressed here that the amount of unemployment benefit depends on the previously received remuneration and is equivalent to $75 \%$ or $70 \%$ of the remuneration (after two months of the receiving of benefit). If an unemployed person takes up work for a lower salary than they previously received, there is a continuation of benefit payment. It is paid at a lower rate (e.g. $70 \%$ of the difference between the previous and current remuneration), but, in combination with the remuneration received for work, such a person receives more than in their period of occupational inactivity. ${ }^{133}$ The Act provides for a general definition of an unemployed person (one of the conditions is in the form of the loss of at least 5 hours a day or half a week's working time $)^{134}$ and lays down general rules for the payment of benefits. There are no specific provisions for older people. Prolongation of the benefit period (over 3 months), as already mentioned above, is possible through demonstration of appropriate

127 Early retirement and early exit from the labour market occur particularly among those who are physical workers with reduced working capacity before reaching the general retirement age. More details in: R. van het Kaar, F. Tros, The Netherlands: The Role of Governments..., p. 3.

$128 \mathrm{Ibidem}$, and the literature cited therein.

129 R. van het Kaar, F. Tros, The Netherlands: The Role of Governments..., pp. 3-4.

130 Werkloosheidswet.

131 Ibidem.

132 More details N. Gundt, The Protection of Unemployed..., p. 23.

133 Ibidem, p. 22.

134 Definition of unemployed person and conditions: MISSOC, Comparative Tables on Social Protection, Netherlands, Unemployment, available at http://missoc.org/MISSOC/ INFORMATIONBASE/COMPARATIVETABLES/MISSOCDATABASE/comparativeTablesSearchResultTree.jsp, (accessed: September 2017).). 
periods of employment. The maximum period of benefit from January $1^{\text {st }}, 2016$ is 24 months. Despite the fact that the above solutions are not addressed specifically to older people, it does seem that they may frequently be its beneficiaries.

Particular attention should be drawn to the assistance provided in Dutch legislation to older persons and to the partially disabled unemployed. The basis for the payment of benefits for the indicated categories are two separate acts. Benefits are paid on the basis of derogations from the previously described rigorous eligibility rules. The first is granted to persons born before January $1^{\text {st }}, 1965$ who became unemployed after reaching the age of 50 . Benefits are paid until beneficiaries reach retirement age. ${ }^{135}$ The second normative act is transitory. It is valid until 2027 and offers benefits for those who became unemployed between 1.09.2016 and 1.01.2020, provided they are 60 and fulfill the additional conditions set out in the Act. The allowance cannot exceed the statutory minimum wage, but is paid regardless of the partner's earnings or assets held. The benefits are also available to persons recognised as partially disabled if they have reached the age mentioned above. ${ }^{136}$

It is noticeable that the training system for the older persons in the Netherlands is less developed and less advantageous than that for the young. Pursuant to general regulations, employers are required to organize training when necessary for an employee to perform a specific job. In addition, employers are required to organize vocational training for alternative work if the employee is unable to perform their current tasks or there is lack of demand for this. In these cases, the costs of training cannot generally be recovered from the aforementioned funds for transfer to another job (transitory compensation) paid in the event of redundancies. ${ }^{137}$ As far as the organization of vocational training is concerned, the above-mentioned unemployment benefit law provides individual reintegration programmes carried out by the relevant entities (within the first three months of job-seeking), individual counselling (after three months of job-seeking), internships in enterprises (up to 26 weeks) and specific cases of gaining professional experience in the case of those who have particular difficulties in finding suitable work (unpaid work for a period of two years in activation centres). ${ }^{138}$

Attention should be paid to forms of support for Dutch employers hiring persons partially incapable for work and the older unemployed. The aim here is to exempt employers from the obligation to pay sickness compensation if the issue occurs during the five-year period starting from the date of employment of the above persons. In addition, social security contributions are reduced for the employment of the aforementioned persons. There is also an opportunity for employers to apply for subsidies in the case of employment of a person who is covered by social welfare

135 The pension then replaces the benefit.

136 For more details see N. Gundt, The Protection of Unemployed..., pp. 26-27. Compare also information available at: MISSOC, Comparative Tables on Social Protection, Netherlands, Unemployment. Benefits for Older Unemployed. 2 Conditions...

137 N. Gundt, The Protection of Unemployed..., p. 28.

138 Ibidem, pp. 29-31. 
benefits. In such cases, the employer pays the minimum wage, up to $70 \%$ of which is compensated. 139

With regard to policies aimed at prolonging the professional activity of the older person, attention is paid to the measures taken to encourage delayed retirement. These include numerous social partner agreements implementing the principle of partial retirement and the existence of diversified financial incentives for both employees and employers. Among these are: a reduction in the burden of social security contributions, granting bonuses to low-paid employees over 61 years of age (carry-on-working discount), as well as long-term sickness arrangements for the older person (employers pay sick pay for a period of 2 years). ${ }^{140}$ Active labour market policies that encourage the employment of older people include programs aimed at the development of counselling and intermediation between potential employers and the older person. However, it was noted that they did not produce the expected results. 141

When it comes to benefits aimed at providing individuals with the minimum subsistence level, the minimum income guarantee must be taken into account. The amount of this allowance is determined on the basis of the minimum wage and adult household members. It cannot be higher than the difference between the earned income and the minimum subsistence level. For single persons, age is a significant factor. ${ }^{142}$ Another type of support, addressed to all persons meeting the criteria, is assistance provided under the aforementioned Participation Act. The Act provides assistance to persons who do not have income that meets the minimum subsistence level, all income and assets held are taken into account when determining the aid. The main purpose of the Act is to help the beneficiary get out of the social assistance system as soon as possible. ${ }^{143}$ The Participation Act provides also job search assistance and measures for those who are not fit to find a job on their own. It also includes, among other things, carrying out unpaid work in order to gain professional experience, completing unfinished education, receiving activation vouchers (approx. EUR 2,500 a year, in addition to social assistance benefits) or being sent to sheltered jobs, which is planned as a last resort measure. ${ }^{144}$

Some benefits may apply to older disabled people before they reach the retirement age. Permanent incapacity benefit (granted under the IVA Act) is paid to people who have not reached retirement age and have a permanent and full (minimum $80 \%$ ) incapacity for work, whose earning capacity is below $20 \%$ of the basic; if there is no or little possibility for improvement. The partial incapacity benefit (WGA) is paid to individuals before reaching retirement age who have an established partial (from 35\% to 79\%) or a full but temporary (from $80 \%$ to $100 \%$ ) incapacity to work

139 For more details see N. Gundt, The Protection of Unemployed..., p. 32.

140 R. van het Kaar, F. Tros, The Netherlands: The Role of Governments..., p. 4.

141 More on this: ibidem, pp. 4-5.

142 N. Gundt, The Protection of Unemployed..., p. 24.

$143 \mathrm{Ibidem}$. Assets are not taken into account for the aforementioned benefit.

144 Ibidem, p. 31. 
with an earning potential less than $65 \%$ of the basic wage. Additional benefits are also available for people with a permanent or partial disability. ${ }^{145}$ Upon reaching retirement age, the old-age pension replaces this.

\subsection{Right to retirement pension and other benefits}

In Lithuania the conditions governing the granting and payment of pensions are provided for in the Law on State Social Insurance Pensions of 18 July $1994^{146}$ and the Early Pensions Act of 16 October 2003. ${ }^{147}$ There is no partial pension. ${ }^{148}$ There is no tax due on pensions and no contributions are paid. A person who is at retirement age and has had insurance contributions paid for at least 15 years is entitled to an oldage pension. The retirement age for women and men is different: for women, in 2015, it was 61 years and 4 months, while for men it was 63 years and 2 months. For both women and men, born after 1961, the retirement age of 65 will be applied in 2026. 149 Obtaining the highest possible pension requires the retiree to have worked for at least 30 years. Pensions consist of three parts: basic, supplementary and length of service allowance. ${ }^{150}$ The level of the basic pension depends on the provisions of the government and takes inflation into account. Persons with 30 years of service draw $€ 118.80$ ( $110 \%$ of the basic pension). The supplementary part of the pension depends on the length of insurance and the amount of income received. The supplementary part is calculated with consideration to the total number of years worked as well as the amount of taxable income set by the Government of the Republic of Lithuania in the current year. This year it is $€ 434$. Length of service allowance is paid to persons with work experience of more than 30 years. It is calculated for each full year of work over 30 years and is $€ 3.24$ for each year of work ( $3 \%$ of the base pension amount).

On the other hand, an early retirement pension is paid in Lithuania when there is no more than 5 years left to reaching retirement age provided that the person has at least 30 years of insurance coverage. The exception to this requirement applies to persons who gave birth to and/or raised five or more children over

145 More information: Social Security Administration..., p. 229.

146 Valstybinių socialinio draudimo pensiju istatymas) of 18 July 1994 (No. I-549).

147 Valstybinių socialinio draudimo senatvès pensijų išankstinio mokejjimo įstatymas) of 16 October 2003 (No. IX-1828).

148 In the Republic of Lithuania there are, inter alia, disability pensions (due to loss of ability to work), state pensions and pensions for researchers.

149 Lietuvos Respublikos Vyriausybès $2011 \mathrm{~m}$. Liepos $13 \mathrm{~d}$. nutarimas Nr. 836, available on http://www.pensijusistema.lt/index.php?619557871, (accessed: January 2016).

150 See also A. Mažionienè, D. Valeckienè, I. Mažionytė, D. Beržinytė, T. Aleksandravičiutè, D. Bliudžiutè, R. Razmutè, K. Zakarauskaitè, Ageing in Lithuania, Klaipeda 2011, pp. 1415, http://www.mep_activeageing.ipleiria.pt/files/2012/01/Klaipeda-State-College1. pdf, (accessed: January 2016). 
a period of 8 years, and persons with responsibility for dependents. For such persons, a 15 year insurance period is required. The additional condition is, however, that the persons do not receive additional revenue (e.g. benefits from social assistance) and neither worked nor engaged in agricultural activity. Therefore, should a person take up employment or go self-employment, the early retirement pension would be suspended. Early retirement pension is calculated the same way as a full pension; however, it is reduced by 0.4 percent for each full month remaining until retirement age. This mechanism is to act as a deterrent to early retirement. For example, if you receive an early retirement pension for 5 years (60 months), your calculated amount is $€ 240$. However, the amount actually paid will be $24 \%$ lower $(60 \times 0.4$ percent $=24$ percent $)$ and will be $€ 182.40$. The average early pension is currently $€ 175.14$. Due to the fact that from 2012 the retirement age is being gradually extended (for men by 4 months/ for women - by 2 months), it is the date of acquisition that determines the right to a pension. 151

In the Czech Republic the rules for the acquisition and payment of pensions are laid down in the Pension Insurance Act of 1 January 2010.152 Significant changes in this legal Act entered into force in September 2011. The acquisition of the right to a pension under Czech legislation is subject to the following conditions. Firstly, reaching retirement age 153 and secondly, having a certain contribution period. It worth highlighting that the Czech legislator made certain subjective differentiations. Among these we can distinguish between insured persons born before 1936, insured persons born between 1936 and 1977 and insured persons born after 1977. For insured individuals born prior to 1936, pensionable age varies according to gender. For men born before 1936, the retirement age is set at 60 . Whereas, women in this age group have varied pensionable age limits. This is based on the number of children raised by women; and ranges from 53 to 57 years (53 - when a woman has raised at least 5 children, 54 - from 3 to 4 children, 55 - at least 2 children, 56 - at least 1 child, 57 - in the case of women without children). For people born between 1936 and 1977, the retirement age is gradually extended, ${ }^{154}$ though the pensionable age limit still depends on the number of children brought up. It is interesting

151 Sodra, Senatves pensija, http://www.sodra.lt/lt/situacijos/informacija-gyventojams/ noriu-gauti-pensija/senatves-pensija, (accessed: January 2016).

152 Act No. 155/1995 Coll. on Basic Pension Insurance (Zákon o důchodovém pojištění).

153 The provisions introducing an extension of the statutory retirement age in the Czech legislation system were a response to the increase in the average life expectancy of the Czech population. The reforms introduced in the pension system were aimed at prolonging the working life of older people and eliminating structures contributing to their early exit from the labour market. These included, for example, the construction of an early retirement pension which results in a reduction of the old-age pension, as well as provisions limiting earnings in the case of receiving an early retirement pension, J. Hála, Czech Republic: The Role of Governments..., (e-source).

154 For example, for persons born in 1965 when raising at least four children, the retirement age will be 61.8 (the age limit is extended when a woman has brought up fewer children, to 63.2 - when raising at least 3 children, to 64.8 - at least 2 children). 
to note that childless women who were born in 1962 and later will have the same retirement age as women with one child. For people born in 1977, it will be 67 years. Another category is insured persons born after 1977. For insured individuals born after 1977 the number of calendar months that equals twice the difference between the year of birth and 1977 is added to the age of 67 years. The last group of insured persons are those who are covered by the legislation in force prior to January $1^{\text {st }}$, 1996. However, this applies to persons who have worked for the specified periods or who were members of the underground resistance. 155

As already indicated earlier, the acquisition of pension rights depends not only on reaching the retirement age mentioned above, but also on the length of insurance payments. Depending on the periods of insurance held, different types of pension benefits are distinguished, as defined in Article 29 of the Czech Act: an old-age pension linked to reaching the retirement age, a proportional pension, a pension due after a 30-year insurance period, a pension following a valid assessment under the conditions for receiving a disability pension. ${ }^{156}$ The periods of insurance required vary depending on the retirement age or the age of the insured person. As regards the old-age pension, the period of insurance gradually increases depending on the retirement age and the age of the insured person. The minimum period for entitlement to a pension in the case of retirement age reached before 2010 is 25 years of insurance. For insured persons reaching retirement age after 2018, the insurance period will be 35 years. Consequently, it is decisive for the acquisition of pension rights to have a sufficient insurance period at the date of reaching retirement age.

Noteworthy that in Slovak Republic the pension system has undergone significant changes as a result of the 2004-2005 reforms aimed at ensuring the adequacy and suitability of the pension system and its adaptation to demographic changes. As a result, fundamental changes were made. These included an increase in the impact the salary earned had on the pension received, and a gradual increase in the retirement age from 60 for men and from 53-57 for women up to 62. According to which, men were to reach this retirement age in 2008 and women in 2024. ${ }^{157}$ It is important that this only applies to men born in 1946 and later and women born in1962 and later. Starting from 2017, the general retirement age for people born after December $31^{\text {st }}$, 1954 will be calculated equally for men and women, taking into account the increasing average life expectancy. ${ }^{158}$ However, the retirement age for women raising children, has been reduced. This applies to women born before $1962 .{ }^{159}$ For example, women who raised five or more children could retire in 2014 at the age of 57.5. In addition, people raising children under the age of six are supported by the payment of pension contributions by the state. The contribution

155 Czech Social Security Administration, Old-age Pension, available at: http://www.cssz. cz/en/pension-insurance/old-age-pension.htm, (accessed: September 2017)..

156 Ibidem.

157 L. Vagač, EEO Review: Employment Policies..., p. 3.

158 M. Kahanec, M. Sedláková, Social and Employment..., p. 19.

159 Ibidem. 
payment basis is $60 \%$ of the average income received over the two-year period preceding child raising responsibilities. ${ }^{160}$ As a result of subsequent amendments to the pension's regulation ${ }^{161}$ in 2008 in Slovakia, a minimum contribution period of 15 years was introduced, which is a $50 \%$ increase compared to the previously required 10-year period.

In Slovakia the pension consists of two components, specifically a basic assessment and a percentage assessment. The amount of the basic assessment of the pensions is set as a percentage of the average wage - $9 \%$ of the average wage (rounded appropriately). The percentage assessment is $1.5 \%$ of the calculation base for each year of the insurance before the entitlement to the pension arose. ${ }^{162}$ The determining factors for the pension rate are: earnings and number of insured years. A proportional pension, concerns persons who cannot acquire the right to a pension under the previously defined rules and is available for those who have reached the minimum insurance period. For persons who reach the age of 65 years before 2010, the insurance period is at least 15 years. Successive insurance periods range from 16 to 20 years, based on the increasing age of retirement. It should be stressed here that further periods of insurance and retirement age limits are only applicable to insured men.

In accordance with the Slovak Social Insurance Act, starting from December $31^{\text {st }}, 2009$, those insured persons who have acquired the right to a retirement pension (in accordance with the rules laid down in Article 29 of the Act) may work and receive a full pension, regardless of the type of work and the amount of their income. However, persons receiving a pension and income from work may request payment of half of the full amount. ${ }^{163}$ Those who earn an income after acquiring the right to a pension but who have suspended the pension receive an increase in the pension for each 90 -day income period of 1.5\% of the base (Art. 34 (2)). This increase also takes place in the event of income being earned with the pension received. Then, however, there is an increase of $0.5 \%$ in the base for every 360 days of income. On the other hand, if one takes half of one's pension, there is an increase of $1.5 \%$ in the base for every 180 days. However, this applies only after December $31^{\text {st }}, 2009$. The basic amount is $770 \mathrm{CZK}$ for each month. ${ }^{164} \mathrm{It}$ is worth highlighting that only higher pensions which exceed a multiple of 36 of the minimum monthly wage annually are subject to tax.

160 OECD, "Pensions at a Glance 2015: Country Profiles - Slovak Republic", [in:] Pensions at a Glance 2015: OECD and 20 G Indicators, Paris 2015, p. 338, DOI: http://dx.doi. org/10.1787/pension_glance-2015-75-en.

161 Law on Old-age Pension Savings (Zákon o starobnom dôchodkovom sporení) 2004, No. 43.

162 For more see MISSOC, Comparative Tables in Social Protection, Czech Republic: Old-age, http://www.missoc.org/MISSOC/INFORMATIONBASE/COMPARATIVETABLES/MISSOCDATABASE/comparativeTablesSearchResultTree.jsp, (accessed: September 2017)..

163 See Czech Social Security Administration.

164 Ministry of Labour and Social Affairs, Old-age Pension, available at: http://www.mpsv. cz/en/12954, (accessed: September 2017).. 
The insured person in Slovakia shall be entitled to the early retirement up to three years prior to the legal retirement age if the retirement age of the insured person is less than 63 years; or up to five years prior to the legal retirement age if the retirement age of the insured person is more than 63 years and the person is at least 60 . The claimant must be at least 60 and have an insurance period of at least 33 years. 165 The amount of the early permanently-reduced old-age pension (Section (\$) 36 of the Act on pension insurance) shall be lowered for every (commenced) 90day period of early retirement by: $0.9 \%$ of the calculation basis for the first 360 calendar days, $1.2 \%$ of the calculation basis for the period between $361^{\text {st }}$ and $720^{\text {th }}$ day, $1.5 \%$ of the calculation basis after the $721^{\text {st }}$ day. ${ }^{166}$ These reductions are permanent and therefore continue after the recipient reaches normal retirement age. The cumulation of early pension with earnings is not allowed.

It should be emphasised that Slovak legislation did not provide a minimum pension for a long period of time. In order to counteract poverty among people who had received low wages during their professional career, a minimum pension was introduced after July 2015, amounting to EUR 269.50 in the 2015-2016 period, calculated as a percentage of the minimum subsistence (it is 1.36 times this minimum). ${ }^{167}$ The minimum pension shall be paid to persons with a minimum insurance period of at least 30 years and provided if the insured person has received at least $24.1 \%$ of the average remuneration in a given year. ${ }^{168}$ It is noted that the solutions adopted exclude those who are particularly in need, at risk of poverty and social exclusion.

In Slovakia the system of social protection operates through instruments for assistance in material need (The Act on Assistance in Material Need ${ }^{169}$ ) and provides not only basic assistance in material need but also specific allowances for health care, housing, an allowance to promote the activation of citizens in material need and protective benefits. It also provides for life situations in which citizens in material need cannot secure income through their own work due to their age, incapacity for work or the need to provide twenty-four hour care for a citizen or child deemed to have a severe disability. ${ }^{170}$ Pensioners are also entitled to the minimum income guarantee from the above Act. On 1 January 2014, this minimum guarantee consisted of several parts: a monthly allowance, a housing allowance, and a monthly protective benefit.

165 MISSOC, Comparative Tables in Social Protection, Czech Republic: Old-age.

166 Ministry of Labour and Social Affairs, Old-age Pension.

167 M. Kahanec, M. Sedláková, Social and Employment..., p. 21.

168 For each additional year of insurance, the sum increases by 2 percentage points, and by 3 percentage points after 40 years of paid contributions. The minimum pension is not means tested. For more see: http://missoc.org/MISSOC/INFORMATIONBASE/ COMPARATIVETABLES/MISSOCDATABASE/comparativeTablesSearchResultTree.jsp, (accessed: September 2017).

169 Act No. 417/2013, effective on July 2014.

170 UNECE, National Report, The Situation of Older People in Slovakia. Combating Poverty, pp. 4-5. 
It is higher for retired couples. During the period under consideration, the benefit was granted to the amount of 180.47 EUR for a single pensioner and to the amount of 322.44 EUR for a couple. It should be stressed that the benefit was paid only to those pensioners without any other sources of income. However, the benefit in question is also paid to pensioners with low pension benefits. In such cases, however, it varies depending on the eligible contribution periods. ${ }^{171}$ As a result of the reforms of the years 2015-2016, the abovementioned Act was amended. These reforms were dictated by the need to combat long-term unemployment and the encouragement of professionally inactive persons to take up employment by providing inter alia concurrent receipt of income from employment and social benefits and payroll tax exemption for one year and a maximum of $67 \%$ of the average wage two years back. ${ }^{172}$ As part of the increased attention on active labour market policies, the Act on Assistance in Material Need, conditioned allowances in material need by participation in public activation works for at least 32 hours per month. In addition, Activation Centers were created in response to the Act on Assistance in Material Need in 2014. ${ }^{173}$

Combating poverty and social exclusion as part of the European Strategy 2020 resulted in a series of reform programmes in the Slovak Republic between 2010 and 2014. Due to the Madrid Action Plan of Action on Ageing Societies, a number of measures have been taken to implement the commitments made under the Madrid Declaration. As regards combating poverty and social exclusion, attention should be paid to the Law on Financial Benefits for Compensation of Disabled Persons (Zákon o peňažných príspevkoch na kompenzáciu tažkého zdravot, which provides for a range of benefits (including, inter alia, care services for dependent persons and other monetary aids for specific purposes) ${ }^{174}$ in order to enable persons with disabilities to lead an independent life and support their integration into society. ${ }^{175}$ Also worth mentioning is the Law on Social Services (Zákon o sociálnych službách), ${ }^{176}$ under which day care centres were established, including for people of retirement age. The draft amendment of the said Act, prepared by the Ministry of Labour, Family and Social Welfare, provides for the introduction of solutions in relation to the growing needs of the older person. This is especially true for their long-term care. ${ }^{177}$ It is worth highlighting that certain specific bonuses, such

171 OECD, "Pensions at a Glance 2015: Country Profiles - Slovak Republic”, p. 339.

172 Taking up a job will now result in the continued payment of the benefit (plus the salary) during the first months to the amount of EUR 126.44. Over the following six months, the amount of the allowance is reduced to EUR 63.07, see ibidem, p. 27.

173 M. Kahanec, M. Sedláková, Social and Employment..., p. 20.

174 It should be underlined that certain types of benefits are not available to older people. This includes benefits for dependent person care and benefits for car purchase. In respect of care benefits for a dependent person, their payment to persons over 65 years of age will be possible provided that this began prior to that age.

175 UNECE, National Report, The Situation of Older People in Slovakia. Combating Poverty, p. 3.

176 Act No 448/2008, as amended.

177 UNECE, National Report, The Situation of Older People in Slovakia. Combating Poverty, p. 4. 
as a Christmas bonus (Vianočný príspevok) are provided for those with pensions (old-age pension, early old-age pension, invalidity pension, social pension, widow pension, widower pension and orphan pension) below $60 \%$ of the average national wage. The maximum amount in 2016 was $€ 100.178$

The retirement pension system in the Netherlands according to the Law on Oldage pensions $\left(\mathrm{AOW}^{179}\right.$ ) provides basic pension entitlement for anyone living and insured in the Netherlands. ${ }^{180}$ The insurance period is indicated as 50 years. ${ }^{181}$ However, there is no requirement for continuous insurance. It is important that a person between the period from 15 years of age ${ }^{182}$ and retirement age was insured for at least one year. Persons born on or after April 1st, 1950 shall not be entitled to a pension if they have not been insured for at least one year. For each year of insurance, a person acquires $2 \%$ of benefits, therefore, after reaching retirement age and having an insurance period of 50 years, he/she will be entitled to $100 \%$ of the pension (full pension). Married couples are entitled to the so-called spousal pension. ${ }^{183}$ In Netherlands, reforms of 2012 led to changes in the retirement age resulting in its intended gradual increase from 65 years to 66 in 2019 and 67 in 2023. However, as a result of changes in 2015 , the age extension process was accelerated, extending the retirement age to 66 years in 2018 and 67 years in $2021 .{ }^{184}$ This may be further increased, taking into account the average life expectancy of the population. In 2022, the legal retirement age, being linked to life expectancy, will be 67 years and 3 months. ${ }^{185}$

The amount of the pension in the Netherlands depends on both the period of insurance and the family situation of the individual. The pension is paid regardless of any earnings of the person concerned. This means that such a person does not have to stop working to receive a pension. Interestingly, pensions are taxed. They are also subject to social security contributions (especially long-term care

178 MISSOC, Comparative Tables on Social Protection Results, Old-age pension, Slovakia.

179 General Old-Age Pensions Act (Algemene Ouderdomswet, AOW).

180 The database contains information on the lack of legal provisions for early retirement and so-called deferred pensions. These may, however, be provided for in sectoral or industrial collective agreements.

181 MISSOC, Comparative Tables on Social Protection - Results, Old - Age Pension, The Netherlands.

182 In connection with extending the retirement age, from 2016 - it is 15 years and 6 months, and from 2021 - from 17 years. See Social Security Administration, Research, Statistics, and Policy Analysis, Social Security Programs Through the World, Europe 2016 (released September 2016), Netherlands, p. 229. Available on: http://ssa.gov, (accessed: September 2017).

183 Ibidem. See also MISSOC, Comparative Tables on Social Protection - Results, Old - Age pension, The Netherlands.

184 The legal retirement age in 2017 is 65 year and 9 months. Ibidem.

185 See official website of the authority, The Sociale Verzekeringsbank, available at: https://www.svb.nl/int/en/aow/wat_is_de_aow/wanneer_aow/index.jsp, (accessed: September 2017). 
contributions and health insurance). The law establishes the minimum amount of benefit. In the case of persons married or living together (partnership) the pension is $50 \%$ of the minimum wage (net) for each of them. In the case of single people, the retirement benefit is $70 \%$ of the above mentioned minimum wage, and in the case of caring for a child under 18 years $-90 \%$ of this remuneration. ${ }^{186}$ Persons who have not acquired the right to a full pension or receive it at a very low amount are entitled to an additional benefit. This benefit is paid on the basis of the Participation Act. Benefit application may be submitted two months before entitlement to a basic pension is acquired. In addition, until recently, there was also a possibility to receive additional benefits if the person entitled to a pension had a partner who was under 65 years of age, provided that he or she had no income or it was meagre (AOW supplementary allowance). ${ }^{187}$ In order to receive the above benefits, the person entitled to a retirement pension had to reach retirement age before January $1^{\text {st }}, 2015$ and be living with a partner who had income not exceeding a certain threshold. The benefit, if taken before January $1^{\text {st }}, 2015$, is paid until the partner reaches retirement age (provided that the other income requirements are fulfilled). This benefit was waived as a result of the amendment of the AOW Act in 2015.

There are also some special supplements. From 1 January 2015, each person entitled to $A O W$ will receive $A O W$ support. The amount of the supplement depends on the number of years one has been a resident in the Netherlands. A holiday allowance (vakantie-uitkering) equal to $6.5 \%$ to $7.0 \%$ of the pension monthly amounts is also paid. 188

\subsection{Concluding remarks}

In Lithuania the discrimination based on age, health problems and the fear of change of older workers, are among the main reasons for their decreasing presence on the labour market. In view of the above, the need to increase the role of collective agreements in terms of shaping working conditions for older workers, as well as increasing the participation of the social partners in shaping policies and legal instruments for the activation of older persons is emphasized. It would also be appropriate to introduce an age management policy. ${ }^{189}$ For this purpose, it is necessary, in particular, to adapt the workplace and the job itself to the capabilities of older workers. This also includes taking the aforementioned changes into account during the process

186 F. Pennings, Social Security Law in the Netherlands, The Netherlands 2013, pp. 143-146.

187 Ibidem, p. 147.

188 MISSOC, Comparative Tables on Social Protection - results, Old - age pension, The Netherlands.

189 Author's opinion. 
of creating new jobs or the adaptation of existing ones. It is noted that the change in the social acceptance of older people and the opinion of them as mentors able to share their experience with younger workers will undoubtedly contribute to retaining older workers on the labour market. 190

The persons over the age of 50 are according to the Lithuanian legislation a group covered by specific support on the labour market to which active means of counteracting unemployment are applied. However, there are generally no legal remedies addressed exclusively to older persons (except for the Seniors Bank). The conditions for providing support for older people's occupational activation include the extension of the duration of benefits (for example: unemployment benefit). Extended subsidizing periods and the amount of subsidies often depends on the fulfillment of additional conditions (for example, having a certain degree of disability, longer unemployment or dismissal for reasons not attributable to the employee). Worthy of special mention is also the fact that the majority of the measures to promote employment are addressed at employers employing people with disabilities. Thus, older persons with a degree of disability have the possibility of additional support in their return to the labour market. There are no specific and distinct measures in Lithuania to encourage employers to hire older people. The framework of the main recommendations on increasing the professional activity of older people is to create conditions enabling a positive work/ life balance, taking account of health and psychophysical conditions. It advises against night work and shift work, recommending in this regard the introduction of: part-time work - this applies to persons of retirement age or pre-retirement age if they have additional income or if they receive a wage above the minimum, flexible working hours, including the right to more frequent, though shorter, breaks, flexible rules for the granting of annual leave, the possibility of dividing leave into smaller parts, transition to part-time work at the request of an employee. ${ }^{191}$ It should be emphasized that some of these solutions are as a result of the introduction of the new Lithuanian Labour Code. However, as noted earlier, most of them are applicable to all workers.

190 S. Lengvinienè, A. Rutkienè, I. Tandzegolskienè, Vyresnio amžiaus asmenų išlikimo darbo rinkoje teoriniai aspektami, Profesinis rengimas: tyrimai ir realijos 2014/25, p. 135 , www.ejournals.vdu.lt/index.php/vocationaltraining/.../250 (accessed: January 2016).

191 See the conclusions formulated in the framework of the project: Vyresnio amžiaus moterų ir vyrų lankstaus darbo metodai ir praktinis taikymas, vši "socializacijos ir darbinio mokymo centras" igyvendinamo projekto "socialinę riziką ir socialinę atskirtį patiriančių asmenų integracija į darbo rinką taikant lankstaus darbo modeli”, nr. vp1(1.3(sadm(02(k(01(020, Vilnius 2009, p. 15, http://www.sidmc.org/project_020/ wp-content/uploads/IV_vyresni_zmones_santrauka.pdf, (accessed: January 2016). Project financing: projektas finansuojamas iš ES 2007-2013 metų Žmogiškųjų išteklių pletros veiksmų programos 1 prioriteto "Kokybiškas užimtumas ir socialine apruptis" VP1(1.3(SADM(02 priemones "Socialines rizikos ir socialinę atskirtį patiriančių asmenų integracija į darbo rinką". 
There are also opinions in Lithuanian literature that the drop in the number of older persons on the register of unemployed is a consequence of the greater involvement of employment services, among others, as a result of the successful implementation of projects co-financed by the European Social Fund addressed to older people as a target group. However, research shows, that most of the people above 50 demonstrate a willingness to work and remain longer on the labour market in general for economic reasons only ( $78 \%$ of respondents). It is therefore more likely that the increase in employment of people at retirement age is more a result of low pensions and their own efforts to remain in work rather than any effective, active employment policies. In the same way, when it comes to the people at preretirement age they continue to work due to the unfavorable conditions of early retirement and its impact on their old age pension. ${ }^{192}$

When it comes to the Czech Republic, attention should be paid to studies highlighting the main obstacles to prolonging the working life of older people. ${ }^{193}$ It is noted that with the extension of the pensionable age, starting in 2013, pre-retirement people will also have other possibilities in addition to the so-called early retirement pension. This is a consequence of the pension scheme reform initiated by the trade unions, resulting in the agreement in the framework of the tripartite national organization. However, this is not a benefit paid by the state, but payments from private pension insurance. The amendment to the law on Supplementary Pension Insurance introduced the possibility of receiving pre-retirement benefits which, in contrast to early retirement, will not affect the basic pension. ${ }^{194}$ Moreover, the beneficiaries of pre-retirement benefits will not have to pay health insurance contributions and, unlike an early retirement pension, will have no restrictions on the possibility of combining pension rights and gainful employment. According to the Ministry of Finance of the Czech Republic, unemployment among pre-retirement aged persons is a serious problem for the entire Czech society and the pre-retirement benefits can contribute significantly to overcoming difficulties faced at this stage of life. ${ }^{195}$ Another challenge provide discrimination based on age. Research conducted by the Empirical Research Centre in 2011 shows that although $85 \%$ of citizens confirm the occurrence of age discrimination, the employment rate of older workers remains high.

In conclusion, it should be emphasized that changes to the Czech Labour Code which make work more flexible are a response to the objectives of the government's strategy. However, as mentioned above, there are no well-developed (expanded)

192 R. Zabarauskaitè, I. Blažienè, Institute of Labor and Social Research, published on 2.06.2013, http://www.eurofound.europa.eu/observatories/eurwork/comparative-information/national-contributions/lithuania-the-role-of-governments-and-social-partners-in-keeping-older-workers-in-the-labour-market, (accessed: January 2016).

193 J. Hála, Czech Republic: The Role of Governments..., (e-source).

194 Ibidem.

195 Ibidem. 
solutions for older people. As far as labour market instruments are concerned, legislative measures targeting the disadvantaged workforce as a whole dominate.

As concerning the comments made to the Slovak regulations, it should be stressed that the share of older people in employment has increased as a result of the extension of the retirement age. Nevertheless, surveys conducted in 2012 showed that the age at which older people leave the labour market was lower than other European Union countries. The changes in the pension system which have led, inter alia, to restrictions on early retirement have been positively assessed. It was underlined that changes in the unemployment benefit system did not affect the position of older people in the labour market. As regards active labour market policies, the lack of an adequate active ageing strategy was pointed out as a significant deficiency during the period considered. The participation of older people in education and vocational training was assessed negatively. It remained one of the lowest in the European Union throughout the period under examination. There is also a noticeable lack of specific policies applied by public employment services exclusively to older people, although people over 50 are included in disadvantaged groups. The lack of specific solutions in the Slovak Labour Code addressed exclusively to the older person even though there are provisions which could facilitate the employment of older persons, should also be pointed out. According to this code, the role of collective labour agreements in shaping working conditions, including, among others, minimum wages, severance pay, shortening of working hours, conditions of overtime work, as well as longer annual leave is highlighted. 196 This is obviously also true for older employees.

It was also noted that tax and insurance arrangements existing in Slovak Republic do not provide significant incentives for employers to hire older people. ${ }^{197}$ Longterm unemployment, work in the black economy and the risk of poverty are also important issues for a large part of Slovak society. ${ }^{198}$ According to the 2013 data, when it comes to identifying the main barriers to prolonging the professional activity of older people, it was emphasised that the pension system does not prevent pension recipients from taking up or continuing in employment. Despite the prolongation of the retirement age to 62 and restrictions on early retirement, the pension system allows pensioners to receive the full pension and, at the same time, to continue their employment. Due to the low level of pensions, as well as the possibility to increase the level of benefit through further work, it is suggested that this may contribute to prolonging the professional activity of pensioners. In 2010 more than $8 \%$ of pensioners benefited from this. Working pensioners, taking into account their months of service, can thus increase the amount of retirement benefits. However, the increase in the pension is lower than in the case of people who decide to suspend their right to these benefits on reaching retirement age. In addition,

196 Cf. H. Barancová, A. Olsovská, Labour Law in the Slovak..., pp. 192-193.

197 L. Vagač, EEO Review: Employment Policies..., p. 9.

198 M. Kahanec, M. Sedláková, Social and Employment..., pp. 12-14. 
tax arrangements are not favourable for those who combine work and retirement pension collection. Such workers are not eligible for the reduced tax base which is available to other employees. 199

It is important to note that some considerations have been given to the issue of the introduction of restrictions on combining the right to an old-age pension with work, motivated by the intention to reduce the employment of pensioners in order to increase employment among young people. However, this idea has not been implemented. The main reason for this was that increasing youth employment should not be achieved at the expense of older employees. ${ }^{200}$ In the Slovak Republic the situation is different with regard to people entitled to early retirement. Early retirees are not entitled to take up employment. It needs to be stressed that, as a result of the pension reforms and the reduction, since 2011, of working opportunities for persons on early retirement, the number of early retirement pensioners has significantly decreased. 201

Stereotyped perceptions of older workers and preference for the employment of young people were identified in Slovakia as an obstacle to prolonging the professional activity of older people. ${ }^{202}$ It is also noted that the employment of people after retirement age is most often based on civil law contracts, since work on this basis is, in general, the only form of employment offered to the older person. It was stressed that access to work for older people has become more feasible thanks to flexible forms of employment, as defined in the Slovak Labour Code ${ }^{203}$ : home-based work, work in reduced working hours, teleworking, flexible working time arrangements and the job-sharing institution introduced in 2011 (which enables the division of labour between two people who set the working hours and tasks to be performed by each person in a specific job position). Another problem which was mentioned with regard to prolonging the professional activity of older people, is the organisation and performance of work taking into account the age of the employed person. The necessity of adaptation to the age of different groups of working people has been observed. There is a lack of specific solutions for older employees in terms of work organisation and working conditions, but the labour code's flexible solutions make it possible to take account of the needs of older workers. Statistical data confirm the interest of people aged 55-64 in taking up part-time work (6.7\% of the total number of employed persons). ${ }^{204}$

It should be stressed that the Netherlands is one of the most effective countries in protecting against poverty and social exclusion. This level of protection is due not only to national regulations but also to collective agreements with the social partners. In the Netherlands as in contrary to the other of analysed countries the system

199 Ibidem.

200 L. Crizia, Slovakia: The Role of the Governments and Social Partners..., (e-source).

201 Ibidem.

202 Ibidem.

203 Act No. 311/2001, as amended.

204 L. Crizia, Slovakia: The Role of the Governments and Social Partners..., (e-source). 
of benefits and the assistance solutions addressed to people with a disadvantageous income and health situation is well developed.

Worth noting are the reforms carried out in 2015 in the Netherlands. These concerned not only both programs and policies on prolonging professional activity, but also changes in legal regulations aimed, among other things, at increasing permanent employment. Given the number of older people employed in parttime or fixed-term contracts, or in other flexible forms, this may also contribute to the growth and prolongation of their professional activity. It is noteworthy that the literature contains critical remarks on the activation measures in law. As, although the main objective is to increase labour market participation, instead of preventive and incentive measures, obligations, sanctions and liabilities prevail. 205

Particularly when comes to Dutch regulations noteworthy are the benefits paid for transfer to another job and protection against redundancies. Apart from a few exceptions (assistance for older unemployed and the unemployed with disabilities), there are no common legal regulations addressed to the older person. As regards the different treatment of older people, and the more favourable shaping of working conditions, collective labour agreements play a special role, with clauses for the automatic termination of employment contracts with persons reaching retirement age highlighted.

205 More details N. Gundt, The Protection of Unemployed..., pp. 41-42. 


\section{Conclusions}

The presented section provides a comparative legal analysis of legal measures aimed at increasing the professional activity of older people. The scope of research, in order to make the results of the comparative legal assessment objective, includes countries from different areas of Europe.

The conducted comparative legal studies show that the problem of ageing populations and demographic decline which affects all the countries in question, necessitates, in each of them, the intensification of activities aimed at prolonging the professional activity of the older person. However, the methods of counteracting the effects of ageing societies, as well as the scope of solutions implemented, despite common directions of action, differ due to the systemic solutions existing in individual countries, the role of social partners, the guaranteed level of social security, as well as cultural traditions. Despite these differences, both the methods used in the countries examined and the final evaluation of the measures applied are often similar.

The countries surveyed were evaluated in several areas. These concern, among others, statistical data on the economic activity of older people, programmes and policies aimed at activating older people, legal regulations to counteract discrimination, employment protection and supporting the ability of older people to perform work; as well as social assistance, pension protection and mitigating the effects of unemployment among older persons.

The subjects of the research are older people. The research was deliberately not narrowed down to a specific age range, nor was a minimum limit of 50+ introduced. This is justified not only by the differences in national legal measures addressed to different groups of people, but also by the range of retirement ages and the way it is being increased in the countries surveyed, as well as by the main research assumption and the related final conclusions of the study.

Neither the older person in employment nor the older unemployed are defined in any of the surveyed countries. The condition of not reaching retirement age (Lithuania, the Netherlands) or not receiving an old-age pension (Slovakia, Lithuania, Czech Republic) is used in the surveyed countries in accordance with the classification of an unemployed person. Such legislation raises a question of a general nature. Should retirement age be a prerequisite for excluding certain persons from being eligible for such measures? ${ }^{1}$ It seems that it is receiving an old-age pension and other income per se but not old age should be the basic conditions disqualifying older people from the group of beneficiaries of assistance solutions provided

1 Compare remarks based on the definition of an unemployed person, provided in Polish law: T. Wrocławska, The Analyses of the Legal Measures..., pp. 431-452. Z. Góral, Komentarz do artykułu 2 ustawy o promocji zatrudnienia i instytucjach rynku pracy [Comment to the article 2 of Law on Employment Promotion and Institutions of Labour Market], [in:] Z. Góral (ed.), Law on Employment Promotion and Institutions of Labour Market. Practical Commentary, Warszawa 2014, pp. 42-101. 
for the unemployed. ${ }^{2}$ Of course, the answer to this question should take into account the statutory retirement age limit and the conditions for acquiring pension rights. The higher the retirement age, which is (as a stand-alone premise) a prerequisite for acquiring the right to a pension, the more convincing is its inclusion in the category of negative premises contained in the definition of an unemployed person. In such cases, it would be worth considering the application of specific aid solutions addressed to job-seekers who do not meet the criteria to be classified as unemployed. ${ }^{3}$

However, it is quite typical to use the term of a (unemployed) person over 50 in normative acts (Slovakia, Lithuania, Czech Republic, Netherlands). Sometimes specific solutions are also applicable to people over 60 (the Netherlands). The above differentiation on the basis of older age implies a presumption that specific legal instruments should also be used for selected groups. ${ }^{4}$ In the absence of such instruments and in the presence of only partial legal regulations, it would be justified to focus not on age, but on other premises which would condition the application of legal solutions.

Specialised courses, education, including vocational training, are provided for people over 50 searching for a job. These people are often referred to as persons requiring additional support (Lithuania), sometimes as persons in a particularly disadvantaged position on the labour market (Slovakia, Czech Republic). Priority is sometimes given to access specific activation measures (Slovakia), and sometimes the mechanism is more comprehensive, including the mandatory establishment of individual activation programmes (Czech Republic), the organisation of specialised courses and vocational training (Czech Republic, Slovakia). Therefore, this particular qualification should determine the selection and application of individual aid solutions. However, more than age, it is the individual situation (dismissal, lack of appropriate qualifications) that should decide on the inclusion of a person in a specific programme. ${ }^{5}$ Any potential determination of an age limit for older people qualifying for separate aid mechanisms should take into account the legal regulations and socio-economic conditions existing in the individual countries. Often, support for the employment of people in a given age group is linked to subsidies for employers (especially Slovakia, Lithuania, Czech Republic). Studies show that high labour costs are one of the main disincentives to the employment of persons of older age. ${ }^{6}$

Certain age ranges of older people are also a prerequisite for the payment of targeted unemployment benefits (Netherlands) or for the payment of unemployment benefits for a longer period of time (Czech Republic, Lithuania). Sometimes periods

2 T. Wrocławska, The Right to Choose..., p. 947-968.

3 See remarks related to definition of unemployed person T. Wroctawska, The Analyses of the Legal..., pp. 433-439.

4 Compare ibidem, p. 444.

5 Ibidem, p. 447.

6 Ibidem. 
of insurance are also decisive for longer benefit payment (Lithuania until 1 June 2017, the Netherlands). Moreover, the assistance measures provided for in the normative acts are often linked to the fact that persons in a given age group fulfill an additional condition relating to the duration of unemployment. Long-term unemployment provides the basis for the implementation of specific programmes for job creation, retraining and career guidance (Lithuania, Czech Republic, Slovakia). In addition, a specific target group for implemented measures is often constituted by older people with disabilities. Additional aid is also sometimes provided to pensioners (Netherlands, Czech Republic). On the other hand, there are also solutions targeted at both pensioners and people over 50 , as exemplified by the institution of the Senior Bank (Lithuania). It is doubtful whether it is advisable to apply a longer period of unemployment benefit payment based on age rather than seniority, inability to work or long-term unemployment. Therefore, older age does not seem to be a suitable and objective measure for the differentiation of the entitlements of the unemployed in the discussed scope. On the other hand, the tendency towards a general shortening of the benefit payment period should be assessed positively, which is usually accompanied by a greater emphasis on active measures to counteract unemployment. Retraining and the acquisition of new qualifications could be considered an alternative to longer periods of payment of unemployment benefit for older people.

As regards legal measures to counteract unemployment among older people, there is a general trend towards moving away from old age as a criterion for the selection of supportive measures, inter alia, disability (often associated with the older person) or long-term unemployment (which also applies in most cases to older people due to their lower qualifications and adaptation difficulties). Thus, one can observe an attempt to equate the situation of older people with other unemployed persons, which consists, inter alia, in the elimination of differentiation of older people (Netherlands, Czech Republic, Lithuania) or the determination of assistance according to criteria that may apply to all the unemployed who have particular difficulties in finding a job. Increasingly, assistance is therefore directed towards people with lower professional qualifications or lower remuneration. Supplementary training and education programmes are becoming increasingly common in this area. Sometimes it is also reflected in a guaranteed minimum wage for people with lower professional qualifications and education (Lithuania). Each of the countries surveyed put particular emphasis on assistance and support for employers. Often the assistance provided takes the form of subsidising the remuneration and contributions of employees, and sometimes the arrangements include the simplification of dismissal procedures and the allocation of an allowance for retraining workers who lose their jobs (Netherlands). Taking into account the relatively frequent shortening of working hours for older people, it is also worth noting the solutions allowing for the payment of benefits to such persons (Netherlands, Lithuania - from 1 July 2017). At the level of regulations on the protection of the sustainability of the employment relationship and the working conditions of older people, 
none of the countries surveyed (apart from minor exceptions) have had any regulations aimed strictly at older employees. However, the lack of specific protection for the sustainability of the employment relationship of people in pre-retirement age should not be criticised. Research carried out so far shows that the prohibition on termination of contracts for people of pre-retirement age has the opposite effect, deterring the hiring of and early dismissal of older people. ${ }^{7}$ Greater efforts should therefore be aimed at monitoring the legitimacy of termination of employment contracts and preventing discrimination, rather than forceful retention of often completely unprofitable employment relationships. ${ }^{8}$

At the level of regulations on the protection of the sustainability of the employment relationship and specific working conditions of older people, none of the countries surveyed (apart from minor exceptions) have had any regulations aimed strictly at older employees. Provisions relating to the protection of health and safety at work of older people are also rare and usually of a general nature. However, research confirms that older age diseases (including cancer) impose a slightly different perspective on the problem of supporting older people's return to work and promoting their employment. In this respect, the increasing role of the social partners and their involvement in the implementation of age management policy at significantly earlier stages should be noted. ${ }^{9}$

On the other hand, privileging provisions apply to persons with family responsibilities, those with health problems (all of the examined countries), as well as persons with disabilities. There are also regulations providing for priority of the application for leave, longer annual leave or use of flexible forms of work (Lithuania). However, in each of the surveyed countries there is an increase in the flexibility of working conditions, as well as the development of atypical forms of employment - often used in the employment of older people. At the same time, measures are being adopted to increase protection in this area, inter alia, by means of guarantees for fixed-term employees and for the self-employed. The adopted direction should be assessed positively. Working outside of a typical employment relationship, (see Netherlands, Slovakia) may be an incentive to increase employment especially of the older person. However, only legal regulation, while preserving the basic elements of social security for the employed, seems to be a solution which deserves special attention as regards persons with difficulties in obtaining permanent employment. ${ }^{10}$ The role of fixed-term employment contracts should also be recognised. An attempt in all the countries surveyed to restrict the signing of these

7 For more see T. Wrocławska, Kodeksowa szczególna ochrona trwałości...; T. Wrocławska, Uwagi na tle wyroku SN..., pp. 229-238.

8 T. Wrocławska, Non-discrimination Principle..., pp. 105-110; T. Wrocławska, Uwagi na tle wyroku SN..., pp. 229-238.

9 T. Wrocławska, Protection and Guarantees for Older Employees with Chronic Diseases (Cancer) Through Labour Legislation in Poland - contribution sent to publishing house in August 2018.

Compare the remarks of T. Wroctawska, The Right to Choose..., pp. 960-968. 
contracts does not seem to be an appropriate solution when it comes to the possibility of providing older people with employment ${ }^{11}$ and reducing the gray economy (shadow/unregistered employment), which is largely created by those contracts.

It can also be noted that in the field of employment, the main differentiation of workers' rights is not the age of older workers, but longer seniority, or, as mentioned above, the family situation (childcare) and disability. This is reflected, among others, in longer notice periods (Slovakia, Czech Republic), higher severance pay (Czech Republic), protection of employment and granting some special rights (Lithuania). Seniority also increases the rights of the unemployed (Lithuania, Netherlands). There are generally no protective provisions in the examined countries with regard to the protection of the sustainability of employment relationships of older employees. Lithuania is an exception in this respect. The Lithuanian Labour Code provides for priority to remain in employment for persons of pre-retirement age during the three years preceding the acquisition of pension rights. Interestingly, until recently, workers with higher seniority in the Netherlands were also given preference during mass redundancies. Following the accusations of discrimination against young people, instead of the lifo rule (last-in-firstout), proportional dismissals across different age groups were introduced. In each of the countries surveyed, however, discrimination on the grounds of age is strictly prohibited, whether in terms of working conditions, recruitment, performance of work or termination of employment contracts. The retirement age in the examined countries may be perceived as invalidating the protection of the sustainability of employment relationship (Lithuania) or as the basis for automatic termination of the employment relationship (Netherlands). In this respect, it would be useful to emphasise the postulate of the exceptional nature of automatic dismissals upon reaching certain retirement age. ${ }^{12}$ The risk of restricting the right to work after a set age in certain occupations and professions could contribute to the loss of highly qualified and professionally experienced people from the labour market. 13

In each of the examined countries, studies have shown that age discrimination against the older person, especially in the recruitment procedure, has occurred, which is caused by the negative perception of older people as workers. Sometimes, however, this is a consequence of their higher earnings (Netherlands). However, with regard to the prohibition of discrimination, the legislation of the countries examined use a general criterion. The prohibition of discrimination does not

11 See remarks made by T. Wrocławska, Umowy na czas określony a zatrudnienie..., pp. 221-239.

12 T. Wrocławska, Non-discrimination Principle..., pp. 105-110; T. Wrocławska, Idea międzypokoleniowego podziału pracy jako kryterium obowiqzzowego przejścia na emeryturę w świetle stanowiska Trybunału Sprawiedliwości UE, [in:] T. Bińczycka-Majewska, M. Włodarczyk (eds.), Współczesne problemy prawa emerytalnego, Warszawa 2015, pp. 109-133.

13 T. Wrocławska, Idea międzypokoleniowego podziału..., pp. 109-133. 
therefore apply only to older people. The question arises as to whether it is appropriate to set out a separate criterion of older age and to introduce regulations related to it. ${ }^{14}$ It seems that in spite of many arguments against very detailed legal regulations, the benefits of such a measure, raising social awareness of this ban and increasing the efforts to counteract discrimination on the grounds of age, could be far more measurable.

The employer's obligations to organise vocational training (educational, retraining), which is especially important for older workers (Slovakia, Netherlands) is particularly positive. Worth highlighting here are Dutch solutions, in which the extremely high severance pay for people who are being dismissed is replaced by training benefits.

When it comes to working conditions, there are, in general, no specific regulations addressed to older people in any of the countries surveyed. Shorter working hours, longer annual leave and longer rest periods may be better shaped in collective agreements for older workers. A particular example is the Netherlands, although it is considered that such practices may be seen as discriminatory against other employed persons. Only the Slovak Labour Code contains provisions which mention the possibility of refusing to work night shifts or overtime work by a person over 50 .

As far as the active ageing index is concerned, the Netherlands in particular shows a high level (39.9 points), followed by the Czech Republic (34.8 points). Lithuania is ranked lower (31.7 points), while Slovakia is the lowest (28.5 points). Interestingly, all of the surveyed countries are ahead of Poland (28.2 points). ${ }^{15}$ Similarly, when it comes to the professional activity of people aged 55-64, a high level, above the EU average, is observed in the Netherlands, Lithuania and the Czech Republic, while worse indicators, below the average, are reported in Slovakia. In each of the countries surveyed, the professional activity rate of women is lower than that of men. In the Republic of Lithuania, the difference in employment between women and men is not significant (around 4 percentage points), although it is relatively high in the rest: in Slovakia by over 15 points, while in the Netherlands and in the Czech Republic it amounts to over 20 percentage points. ${ }^{16}$ It is noted that when it comes to countries where retirement benefits are low, an increase in the participation of the older person in work is more often a consequence of pensions being at an insufficient level than of the effectiveness of active labour market policies.

The reasons for the low participation of older people in employment in the countries surveyed include: early exit from the labour market due to the possibility of early retirement, unacceptable working conditions for older workers, transition

14 T. Wrocławska, Non-discrimination Principle..., pp. 105-110.

15 European Commission, Active Ageing Index for 28 European Union Countries, November 2014, http://www.unece.org/fileadmin/DAM/pau/age/WG7/Documents/Policy_Brief_ AAI_for_EG_V2.pdf (accessed: 1.02.2016). 
to self-employment or employment offers on the basis of fixed-term employment contracts. Therefore, it is worth emphasising the restrictions of recent years concerning the acquisition of early retirement pensions (Slovakia, Czech Republic, Lithuania), the combination of early retirement and work (Slovakia, Lithuania), or the setting of an income threshold at which early retirement may be combined with work (Czech Republic), as well as attempts to prohibit employment after the acquisition of basic pension rights (Slovakia). Also noteworthy are the regulations providing for the payment of a full pension depending on insurance periods (Lithuania, Netherlands). There are no restrictions in the countries surveyed on combining an old-age pension with work.

In almost all of the countries surveyed, incentives for longer working lives after the acquisition of universal pension rights were adopted. The suspension of pension collection results in their increase in Lithuania, the Czech Republic and Slovakia, while taking a partial pension while continuing professional activity leads to a lower increase in the said pension (Slovakia). Some of the countries surveyed have set limits on the suspending of old-age pensions by setting maximum (Lithuania) and minimum periods (Czech Republic). Others have introduced conditions for acquiring full pension rights (Netherlands, Lithuania).

It is important that each of the surveyed countries continues its efforts to extend the retirement age. In some of them, the age limit is set on the increase in the average life expectancy of the population (Slovakia, Netherlands). The minimum periods of insurance are identical in some countries (Czech Republic, Slovakia) and exist in general in all countries surveyed, except the Netherlands. Particularly noteworthy is the fact that in some of the countries women's retirement age varies according to the number of children raised (Slovakia, Czech Republic). However, the solution which makes the payment of the basic pension dependent on the current family status (Netherlands) is an isolated one. In some of the countries surveyed, pensions were taxed (Czech Republic, Netherlands) and in the Netherlands social insurance contributions are also deducted from pensions (e. g. for long-term care and health care).

To sum up, in each of the countries surveyed, efforts were intensified to implement policies aimed at prolonging the professional activity of the older person. It is also worth noting that most include solutions which increase the participation of older persons in training and education, reducing early retirement pensions (Slovakia, Lithuania, Czech Republic) and an increase in basic pensions due to longer professional activity (Lithuania, Slovakia, Czech Republic). There are also less common provisions; of reducing protection due to redundancies and replacing it with retraining and assistance in obtaining another job (Netherlands) and establishing an online database for senior citizens (Lithuania).

To conclude these considerations, it is worth emphasizing that solutions aimed at prolonging the professional activity of older people is connected with multidimensional issues, such as, among others, sustainability of the employment relationship, protection against discrimination, health care, measures supporting the return 
to work, as well as the possibility of combining work with family responsibilities, or adapting working conditions to the older person and require an answer related to the basis of the method of regulation (statutory regulations or collective agreement). The scope and level of detail of legal regulations constitutes another challenge, which is burdened with the risk of overregulation and, consequently, frequent changes. Choosing the statutory basis for regulations related to older people it is required to choose the manner of regulation: introducing further regulations or establishing exemptions from general rules. It seems, however, that since the pace of change affecting the situation of older people is extremely dynamic - dependent on social conditions, both economic and political - the most appropriate means should be to increase the participation of social partners. ${ }^{17}$ Finally, a conclusion can also be drawn on the need to distinguish between two groups of older people - preretirement individuals and those reaching retirement age. This may also be an essential criterion for the differentiation of older people's entitlements when it comes to their position in employment and their professional activity.

17 For more see T. Wrocławska, The Right to Choose..., pp. 947-968. 


\section{Part III}

\section{Mirostaw Włodarczyk}

\section{Structural elements of the model of counteracting unemployment among older people}

1. The characteristics of the theoretical model of counteracting unemployment among older people should begin with the definition of recipients and beneficiaries of the legal structures in question. In practice, within the countries surveyed, we do not generally encounter the definition of an older person, and the individual legal constructs usually have their own definition based on their own, individual, situation. Thus, depending on the objectives of a given institution and the current social climes, the number of persons classified as so may vary. The lowest stated age is 45 ; more rights are granted to those who are over 50 and even more are guaranteed to those who reach the age of 55; obviously, anyone over sixty years of age is included. However, the upper age limit for which workplace protection is guaranteed is almost always the general retirement age - with the exception that when this threshold varies between men and women (it is lower for women), the upper limit of the policy measures is the retirement age of men.

2. The construction of a detailed model of counteracting unemployment among the older people will be based on a scheme in which tasks will be distinguished that will, in each case, be the basis for searching for practical devices serving their implementation. Due to the adopted research assumptions, the search for these devices is limited to an examination of legal structures. The distinction of these tasks, as well as the legal devices used to fulfill them, is based on the results of research carried out within the project. The following remarks will avoid the need for explanations relating to the definition of the content of these tasks. The main assumption of the model is therefore 
to indicate what matters should be taken into account in the framework of the state's labour market policy in order to be able to say that it is a comprehensive policy from the point of view of the needs of this market.

\section{Task 1. Building social awareness towards a positive perception of the employment of older people by social partners and other market players}

The need to develop social awareness results from the fact that although it may seem that the need to extend the professional activity of each individual is unquestionable, in practice, taking detailed decisions and actions aimed at achieving such an objective often gives rise to significant resistance. Sometimes it results from the presentlyaccepted patterns of conduct and stereotypes. Such resistance can be justified when changes to policy in this area result in an increase in business or social costs - it is necessary, however, to consider the long-term benefits that are expected to outweigh any current losses, sometimes significantly.

Actions with this aim have been set in progress in a number of countries, with the model the National Program on Ageing Workers implemented in Finland in the years 1998-2002 serving as an ideal example. The main objective of this project was to promote activities aimed at sustaining the employability of people of working age, stimulating employment and building positive attitudes towards people at pre-retirement age (45-55) and older people (55-65). One of the programme's main specific objectives was to change attitudes towards the employment of older people. This was to be achieved through a large-scale media, workplace and general public information campaign on the status of, opportunities for and strengths of an ageing workforce. The campaign emphasized that older people's experience of is a national asset. The campaign resulted in a positive change of social attitude towards older people in the working environment on the part of all market participants. Training courses were an important tool in this respect, especially for employees of labour market institutions that provide services to this category of persons - e. g. health care institutions personnel, employment service staff or teachers conducting classes for adults. Other entities targeted by the information campaign were entrepreneurs, personnel managing employment in enterprises, and personnel responsible for the culture of human resources management.

\section{Task 2. Vocational education and training as a tool to keep older people in employment}

Retaining older people in employment is a complex task, inasmuch as it requires action across various spheres of social life. First and foremost, it is necessary to implement an appropriate vocational education and training policy. The need for lifelong learning is no longer in doubt. In practice, however, and especially with regard to older people, the measures taken in this area until now cannot be regarded as satisfactory. Older people are not trained because they tend to be excessively passive and employers have little interest in funding this process owing to the short duration 
of the benefits accruing from such investments. This means that this process cannot be considered universal (which is required by the idea of lifelong learning). Trainings are used when certain unfavourable phenomena become intensified on the labour market, so they are of an reactionary nature, often with the people chosen for education and training being randomly selected. It is also extremely difficult in such a situation to implement a coherent and consistent employment policy, both on a corporate and, broader, public basis.

Therefore, it does not appear possible to make any progress in this respect without the implementation of a nationwide policy of lifelong learning which promotes continuous improvement of professional qualifications and thus continuous further education throughout the whole working life. This seems to be the only way of eliminating two serious restrictions on older people today: their inadequate qualifications, which should be constantly updated through their working life, and their attitudes towards education, which should become a social norm, not associated with specific life situations (such as, in particular, the state of unemployment).

\section{Task 3. Older people's health - a key determinant of employability}

Good health is essential for the ability to take up and continue employment. The older age phase is a direct result of actions taken in previous stages of life. Therefore, state policy should be directed towards health protection at the earliest stages of a citizen's life. If health protection for young people is provided early enough, then the efficiency of older people will be its conclusion. It should therefore be taken into account that when building model solutions aimed at the employment of older workers, they will only be constructions that complement the general health policy. The legal instruments established should therefore aim at creating health conditions that will allow older people to maintain good health and wellbeing, thus enabling them to remain in employment for as long as possible.

The close link between ageing and incapacity to work is widely recognised. Therefore, it should be a part of the labour market policy to promote vocational rehabilitation for people who hope to return to employment (this is not only aimed at older people). At the same time, and particularly in relation to older people, the need is underlined to assess each case individually; only then should a decision be made on entitlement to incapacity benefits (due to continued poor health) or a return to work. The aim of these measures should be a state in which incapacity benefits do not act as early retirement pensions.

\section{Task 4. Development of age-appropriate working conditions to maintain older people in employment}

The health of older people is strongly affected by the provision of appropriate working conditions. This is about adapting working conditions to their abilities - the working conditions of older workers should take into account their current psychophysical condition (which often gradually deteriorates at this stage of life). Therefore, these employees should work shorter (or non-extended) working 
patterns, avoid night shifts, be exempt from work-related travel obligations, and be freed from arduous work. On the other hand, the advantages of employing such people should also be noted - their mentoring skills in particular should be used to a greater extent. At the same time, adapting the working conditions of older workers to their psycho-physical capabilities should not have a significant impact on their income levels, and it is therefore important to consider at what stage ways of subsidising their employment should be implemented. Of course, it is important to realize that the process of shaping the working conditions of older workers is primarily the responsibility of employers - but public entities can stimulate and supervise this process. Collective agreements establishing the working conditions for older workers, which at the same time build awareness among the social partners of the benefits of employing older workers, can play an important role in the implementation of this task.

The basic methods of shaping working conditions resulting from the conducted research are the flexible organization of working hours, extending the length of holiday leave, changing the type of work performed, and, in particular, limiting or exemption from arduous tasks or introducing part-time work (very often these are connected with subsidizing a part of the remuneration by the state or by covering the costs of certain ancillary costs: health benefits or early retirement).

\section{Task 5. Reducing the employment costs of older workers}

This is about reducing the costs that employers have to bear, which might well lead to an associated heavy burden on public funds. However, this process is considered to be socially beneficial if one considers that the alternative the exclusion of these people from the labour market (which will increase the burden on public funds even further).

Higher employment costs for older workers are caused by a range of circumstances, often due to employment policies adopted years ago, and it is difficult to change them in the short term. One of the main barriers in access to employment for older people is the mechanism of determining remuneration for work based on the criterion of professional experience - hence employers advocate the abolition of remuneration systems based on the length of company service. An example of a solution that reduces the employment costs of older workers is a shorter pay period during sickness.

\section{Task 6. Protection of the sustainability of the employment relationship of older workers}

Employment costs of older workers are usually generated by extended regulations protecting the sustainability of the employment relationship. On the other hand, specific measures aimed at older workers in this area are designed to discourage employers from dismissing older workers and to enable them to remain in employment until they have acquired pension rights. This will be achieved by prohibitions on termination of employment contracts at pre-retirement age, making the length 
of the notice period dependent on the employee's age or length of service, linking to severance pay exemptions - which in the case of older workers are usually higher. These devices certainly protect the employment of an individual worker, but they also discourage employers from employing people who benefit from such protection - thus generating long-term unemployment for older people.

\section{Task 7. Prohibition of discrimination as a means of promoting the return of older people to the labour market}

Anti-discrimination legislation can be an important element in supporting policies to promote the employment of older workers, but it cannot be a stand-alone device in this regard. In particular, positive discrimination may be effective in this respect, an example of which may be a shorter period of payment of guaranteed remuneration during sickness, as it is currently in Poland. The belief that measures are needed to counteract discrimination against older people is widespread - being the point of view of all countries surveyed. The banning discrimination will allow us to assess the effectiveness of those legal structures used for this remit. It is also noted that the effectiveness of anti-discrimination devices can be severely limited by low public awareness.

Lastly, older people who have already obtained universal pension rights should also be protected against discrimination in the workplace, although they no longer need devices to protect their income. In this context, legislative measures to reduce or suspend pensions when starting a career after reaching the normal retirement age should be examined.

\section{Task 8. Subsidized employment as a means of stimulating the return of older people to the labour market}

The loss of employment by an older person and his or her unemployment creates new challenges and needs. In practice, almost all the surveyed countries point to a significant risk of long-term unemployment among older unemployed people. It is therefore argued that this situation requires substantial support for the unemployed older people- even to such an extent that their employment status is protected. This would, in turn, require subsidized employment and the active cooperation of those at risk with public employment services. It should be stated here that in this context there should be no practice of exempting this group of people (after reaching a certain age) from particular obligations incumbent on the unemployed, such as registering at the labour office or actively seeking employment.

The most effective way to stimulate the employment among older members of the workforce is undoubtedly subsidised employment, examples of which, are numerous in the various countries surveyed. The use of subsidised employment is usually necessitated by the existence of negative economic phenomena which generate high unemployment. However, the conditions of employing such measures, which are usually determined by the social goals of the state, are significant. These include: the scope of eligibility for subsidies; the amount of subsidies 
(e. g. full amount of labour costs including taxes and social security contributions or an amount limited e. g. to the social security contributions alone); the duration of the subsidies; the type of employment; the situation on the labour market; the education of eligible persons; the duration of unemployment as a condition for obtaining support).

Subsidies are generally not an effective means of professional activation - their neutral or negative impact on employment growth, high costs, stigmatization of people using them (due to the necessity, because of costs, to limit the use of subsidies to narrow groups of people), high probability of substitution and idle gear effect are highlighted. In spite of this, they are difficult to overlook in the model of counteracting unemployment among older people .

When considering the use of such devices, it is necessary to take into account the significant circumstances which especially affect rich countries. In the examined age group, a significant factor causing long-term unemployment is the relatively low earning opportunities when compared to the high benefits. The reason for this phenomenon is the German doctrine of the so-called threshold wage concept, which indicates the level of remuneration acceptable to jobseekers in a given category - the minimum level of remuneration that older workers are willing to accept is usually much higher than that of younger workers. Therefore, the pressure for this group to be active in the labour market will be higher if the rules on the acquisition of benefits are more restrictive.

\section{Task 9. Use of flexible forms of employment and self-employment as a way to foster the reintegration of older people into to the labour market}

The widespread use of atypical or flexible forms of employment, in particular temporary employment, temporary contract and forms of part-time employment, have been recognized as effective measures to reduce long-term unemployment. However, their use depends on many factors. In rich countries in particular, the use of temporary employment is generally marginal, including for older workers; whereas in poorer countries, this form is more common. Solutions addressed specifically to the older are encountered less frequently. The use of such tools in employment policies for older people, especially those returning from unemployment, should always be carefully considered. They can also be used as a bridge employment method (until the acquisition of pension rights), which is generally not desirable.

Self-employment, on the other hand, as a form of professional activation of older people is mentioned in most of the surveyed countries. In particular, attention is drawn to the fact that this form of activation is not very popular with older unemployed people, and at the same time shows low efficiency in this age group. Hence public authorities often do not generally promote this form of counteracting unemployment among older people. It should also be noted that it is more rational to support the take-up of such activities in earlier stages of working life - since older people, although they can generally have the life and professional experience attributes necessary for such activities, and often also possess adequate capital, 
value leisure time more than the market risk and labour-intensive activities associated with the organization and running a self-employed activity. However, it seems justified to consider the possibility of initially supporting self-employed activities first undertaken at a younger age, which are often then continued into later life, due to their inherent difficulties, which could lead to the cessation of such activities and professional deactivation (in the state of unemployment).

\section{Task 10. Unemployment benefit as a way of both mitigating the effects of unemployment and stimulating the occupational activation of the older people}

The popularity and availability of passive resources (weakly motivating people to seek employment) has a significant impact on perpetuating long-term unemployment. The key issue in all the discussions in this case is the duration of receiving unemployment benefits - both the arrangements for a too limited period and the granting of entitlement to unemployment benefits for an unlimited period of time are criticised. In the case of older people, longer periods of benefits may be considered, but only in certain exceptional circumstances (e. g. the time remaining before pension rights or the situation on the local labour market). It should always be taken into account that the unemployment benefits paid to older people for a long period of time is often used as a bridging benefit to provide until retirement benefits. The employment policies for older people therefore need to determine whether to set up early retirement schemes or replace them with a benefit related to vocational activation.

\section{Task 11. Social assistance and limiting the negative effects of unemployment and promoting vocational activation}

The social assistance system should be harmonized with the unemployment benefit system - especially when it comes to the older people. These benefits very often act as a bridge between pay and employment-related benefits (unemployment benefits, disability benefits) and pension benefits. They almost always have only a passive nature, not motivating the search for employment. In various systems, legislators are trying to eliminate this shortcoming.

\section{Task 12. Principles for the acquisition of pension rights}

In the analysed countries, in various periods of crisis phenomena; and in post-communist countries in early periods of political transformation, the policy of early retirement was often pushed through as an important element of reducing unemployment, which led to early deactivation of the older people. At present, such solutions are seen as inappropriate, even damaging to the economy and especially to social systems. They are also detrimental to the employer and employee as well.

In almost all the countries surveyed, the directions of changes, which have been ongoing for about twenty years, are clear. These are: raising the retirement age, limiting the right to early retirement and increasing incentives to delay the decision to benefit from a pension. 


\section{Task 13. Organisational forms of assistance for older people on the labour market (employment services, participation of social partners, forms of self-organisation)}

The experiences of the surveyed countries indicate that decisions taken in relation to the public-sector labor market and their implementation obligations should be divided between different entities at three levels: national, regional and local. At the same time, however, the role of each individual level should be tailored to the current needs of meeting the objectives.

An appropriate number of officials is also mentioned as a very important condition for the effective operation of public employment services - too low a number is a deficiency of these services in poorer countries. The number of staff directly influences the possibility of maintaining contact between the unemployed and the employment office - only a frequent prospect of contacts with these institutions has a positive impact on the attitude towards seeking employment.

The process of profiling the unemployed is considered a very positive one in the practice of counteracting unemployment among older people.

In particular, three types of activities are used in the process of providing assistance to the unemployed (also to the older unemployed): vocational guidance and retraining, workplace training and subsidized employment. Employment services, due to their limited capabilities, almost always limit their assistance to the first form, while the greatest effects are achieved by the use of all trainings and the development of professional qualifications, especially in the workplace.

Studies show that the role of the social partners should be significant in the implementation of labour market policy (including in relation to older people), however the effectiveness of their actions depends, to a large extent, on unionisation, i.e. on the extent of trade union influence on employment relations. Where possible, arrangements for the implementation of various legislative structures and policies for older people should be adopted by the social partners at the level of the establishment, industry or country. 


\section{References}

\section{List of legal acts}

Belgian Collective Agreement No. 10 of 1973, Convention collective de travail n 10 du 8 mai 1973 relative aux licenciements collectifs, http://www.cnt-nar.be/CCT-COORD/cct-010.pdf, (accessed: 22.04.2016).

Belgian Collective Agreement No. 24 of 1975, Convention collective de travail n 24 du 2 octobre 1975 concernant la procédure d'information et de consultation des représentants des travailleurs en matière de licenciements collectifs, http://www.cnt-nar.be/CCT-COORD/cct-024.pdf, (accessed: 22.04.2016).

Belgian Collective Agreement No. 38 of 1983, Convention collective de travail n 38 du 6 décembre 1983 concernant le recrutement et la sélection de travailleurs, http://www.cnt-nar.be/CCT-COORD/cct-038.pdf, (accessed: 11.04.2016).

Belgian Collective Agreement No. 46 of 1990, Convention collective de travail nº 46 du 23 mars 1990 relative aux mesures d'encadrement du travail en équipes comportant des prestations de nuit ainsi que d'autres formes de travail comportant des prestations de nuit, http://www.cnt-nar. be/CCT-COORD/cct-046.pdf, (accessed: 25.04.2016).

Belgian Collective Agreement No. 77 of 2001, Convention collective de travail n 77 du 14 février 2001 Instaurant un système de crédit temps, de diminution de carrière et de réduction des prestations de travail à mi-temps, http://www.cnt-nar.be/CCT-COORD/cct-077-bis.pdf, (accessed: 25.04.2016).

Belgian Collective Agreement No. 95 of 2008, Convention collective de travail no 95 du 10 octobre 2008 concernant l'egalite de traitement Durant tutes les phases de la relation de travail, http:// www.cnt-nar.be/CCT-COORD/cct-095.pdf, (accessed: 11.04.2016).

Belgian Law of 3 July 1978 on the employment contract, Loi relative aux contrats de travail, Moniteur belge 1978.08.22, No.70303, http://www.ilo.org/dyn/natlex/natlex4.detail?p_lang=en\&p_isn=13103. 
Belgian Law of March 19, 2012 on combating some forms of discrimination, Moniteur belge, 201206-05, n 192, pp. 31670-31677 et modifié plusieurs fois, http://www.ilo.org/dyn/natlex/natlex4. detail?p_lang=en\&p_isn=90258\&p_country $=B E L \& p \_c o u n t=3102 \& p \_c l a s s i f i c a t i o n=05 \& p \_$ classcount $=171$, (accesed : 11.04.2016).

Constitution of the Republic of Poland of 2 April 1997, Journal of Laws 1997 No. 78, item. 483 as amended.

Convention No. 111 of the International Labour Organization of 25 June 1958 on discrimination in employment and occupation, Journal of Laws 1961, No. 42, item 218.

Convention No. 168 of the International Labour Organization of 1 June 1988 on promoting employment and protection against unemployment, http://www.mop.pl/doc/html/conventions/k168. html.

Czech Law on Basic Pension Insurance (Zákon o důchodovém pojištění) of 30 June 1995 (No. 155/1995), as amended.

Czech Law on Employment (Zákon o zaměstnanosti) of 13 May 2004 (No. 435/2004), as amended.

Czech Law on Labour Inspection of 3 May 2005 (No. 251/2005 Coll), as amended.

Czech Labour Code (Zákoník práce) of 21 April 2006 (No. 262/2006 Coll). http://www.mpsv.cz/files/ clanky/3221/Labour_Code_2012.pdf.

Czech Law on Anti-Discrimination of 23 April 2008 (No. 198/2009 Coll), as amended.

Czech Law on Basic Pension Insurance (Zákon o důchodovém pojištění) of 1 January 2010, (No. 155/1995 Coll) as amended.

Danish Law of May 24, 1996 on prohibition of labour market discrimination, Bekendtgørelse af lov om forbud mod forskelsbehandling på arbejdsmarkedet m.v., LBK nr 1349 af 16/12/2008, https:// www.lovtidende.dk/Forms/L0700.aspx?s31=10\&s21=lov+om+forbud+mod+forskelsbehandlin g+p\%c3\%a5+arbejdsmarkedet+m.v., (accessed: 28.06.2016).

Danish Consolidated Law of February 3, 2009 on the employment relationship, Bekendtgørelse af lov om retsforholdet mellem arbejdsgivere og funktionærer, LBK nr 81 af 03/02/2009, https:// www.lovtidende.dk/Forms/L0700.aspx?s31=10\&s21=Funktion\%c3\%a6rloven+, (accessed: 28.06.2016).

Dutch Law on Old-Age Pensions (Algemene Ouderdomswet, AOW).

Dutch Law on Unemployment Benefits (WW, Werkloosheidswet) of 6 November 1986.

Dutch Law on Work and Security (Wet Werk en Zekerheid) of 14 June 2014.

Dutch Law on Participation (Participatiewet) of 2 July 2014.

Framework Directive of the European Parliament and of the Council 2000/78/EC establishing a general framework for equal treatment in employment and occupation, O.J. L 303, 2.12.2000, pp. 16-22.

German Civil Code of 18 August 1896, Bürgerliches Gesetzbuch in der Fassung der Bekanntmachung vom 2. Januar 2002 (BGBl. I S. 42, 2909; 2003 I S.738), das durch Artikel 3 des Gesetzes vom 24. Mai 2016 (BGBl. I S. 1190) geändert worden ist, http://www.gesetze-im-internet.de/ bundesrecht/bgb/gesamt.pdf, (accessed: 10.07.2016).

German Law of 10 August 1951 on protection against unjustified termination of employment, Kündigungsschutzgesetz in der Fassung der Bekanntmachung vom 25. August 1969 (BGBl. I S. 1317), das zuletzt durch Artikel 3 Absatz 2 des Gesetzes vom 20. April 2013 (BGBl. I S. 868) geändert 
worden ist, http://www.gesetze-im-internet.de/bundesrecht/kschg/gesamt.pdf, (accessed: 10.07.2016).

German Law of 3 September 1953 on working time, Arbeitsgerichtsgesetz in der Fassung der Bekanntmachung vom 2. Juli 1979 (BGBl. I S. 853, 1036), das zuletzt durch Artikel 19 Absatz 6 des Gesetzes vom 23. Dezember 2016 (BGBl. I S. 3234) geändert worden ist.

German Law of 23 July 1996 on the system of gradual retirement, Altersteilzeitgesetz vom 23. Juli 1996 (BGBl. I S. 1078), das zuletzt durch Artikel 4 des Gesetzes vom 28. März 2009 (BGBl. I S. 634) geändert worden ist, http://www.gesetze-im-internet.de/bundesrecht/alttzg_1996/ gesamt.pdf, (accessed: 10.07.2016).

German Social Code Book III, Das Dritte Buch Sozialgesetzbuch - Arbeitsförderung - (Artikel 1 des Gesetzes vom 24. März 1997, BGBl. I S.594, 595), das zuletzt durch Artikel 2 des Gesetzes vom 17. Juli 2017 (BGBl. I S. 2581) geändert worden ist.

German General Law of Equal Treatment of 14 August 2006, Allgemeines Gleichbehandlungsgesetz, vom 14. August 2006 (BGBl. I S. 1897), das zuletzt durch Artikel 8 des Gesetzes vom 3. April 2013 (BGBl. I S. 610) geändert worden ist, http://www.gesetze-im-internet.de/bundesrecht/agg/ gesamt.pdf, (accessed: 10.07.2016).

German Social Code Book II, Das Zweite Buch Sozialgesetzbuch - Grundsicherung für Arbeitsuchende - in der Fassung der Bekanntmachung vom 13. Mai 2011 (BGBl. I S. 850, 2094), das durch Artikel 20 des Gesetzes vom 17. Juli 2017 (BGBl. I S. 2541) geändert worden ist.

Hungarian Law of 22 December 2003 on Equal Treatment and the Promotion of Equal Opportunities, 2003. évi CXXV. törvény az egyenlo bánásmódról és az esélyegyenloség elomozdításáról, Magyar Közlöny, 2003-12-28, No. 157, pp. 13044-13054.

Hungarian Labour Code of 13 December 2011, 2012. évi I. törvény a munka törvénykönyvéröl, Magyar Közlöny, 2012-01-6, vol. 2, pp. 257-316.

Hungarian Law of 1 October 2012 on the Workplace Protection Plan 2012. évi CXLVI. törvény a munkahelyvédelmi akciótervben foglaltak megvalósítása érdekében szükséges egyes törvények módosításáról, Magyar Közlöny, 2012-10-15, vol. 136, pp. 23365-23373.

Lithuanian Act on Education of Older (Lietuvos respublikos neformaliojo suaugusiujų švietimo istatymo) (No. VIII-822).

Lithuanian Labour Code (No. XII-2603). The text of the new code is available at: https://e-seimas.lrs. lt/portal/legalAct/en/TAD/TAIS.191770 (accessed: 1.07.2017).

Lithuanian Law on Social Insurance (Valstybinio socialinio draudimo įstatymas) of 21 May 1991 (No. I-1336).

Lithuanian Law on State Social Insurance Pensions (Valstybiniu socialinio draudimo pensiju istatymas), of 18 July 1994 (No. I-549).

Lithuanian Law on Earlier Retirement Pensions (Valstybiniu socialinio draudimo senatvés pensijy išankstinio mokejjimo įstatymas), of 16 October 2003 (No. IX-1828).

Lithuanian Act on Egual Rights (Lietuvos Respublikos lygiu galimybiu istatymas) of 18 November 2003 (No. IX-1826).

Lithuanian Law on Unemployment Insurance (Nedarbo socialinio draudimo įstatymas) of 16 December 2003 (No. IX-1904).

Lithuanian Law on Support for Employment (Lietuvos Respublikos užimtumo rémimo įstatymas) of 15 June 2006 (No. X-694). 
Lithuanian Law on Support for Employment (Užimtumo rémimo įstatymas) of 14 July 2009 (No. XI-334).

Lithuanian Government Decision (Lietuvos Respublikos Vyriausybès nutarymas) 13 July 2011, (No. 836), available on http://www.pensijusistema.lt/index.php?619557871, (accessed: January 2016).

Lithuanian Law on Employment (Užimtumo įstatymas) of 21 June 2016 (No. XII-2470), in force on 1 July 2017 and replaces the Law on Support for Employment.

Polish Labour Code of 26 June 1974, consolidated text Journal of Laws 2016, item 1666 as amended. Polish Employment Act of 29 December 1989, Journal of Laws No. 75, item 446.

Polish Act of October 16, 1991 on employment and unemployment, Journal of Laws No. 106, item 457.

Polish Act of 14 December 1994 on Employment and Counteracting Unemployment, Journal Journal of Laws 1995, No 1, item 1.

Polish Act of 27 June 1997 on occupational medicine service, consolidated text Journal of Laws 2014. item 1184 as amended.

Polish Act of 17 December 1998 on pensions from the Social Insurance Fund, consolidated text Journal of Laws 2016, item 887 as amended.

Polish Act of 25 June 1999 on cash benefits from social security in the case of sickness and maternity, consolidated text Journal of Laws 2016, item 372.

Polish Act of 10 October, 2002 on the minimum remuneration for work, consolidated text Journal of Laws 2017, item 847.

Polish Act of 20 December 2002 amending the Act on Employment and Counteracting Unemployment and the Act on the Education System, Journal of Laws 2003, No 6, item 65.

Polish Act of 13 March 2003 on special rules for terminating employment relationships for reasons not related to employees, consolidated text Journal of Laws 2016, item 1474.

Polish Act of 13 June 2003 on social employment, consolidated text Journal of Laws 2016, item 1828.

Polish Act of 12 March 2004 on social assistance, consolidated text Journal of Laws 2016, item 930.

Polish Act of 20 April 2004 on promotion of employment and labour market institutions, original text, Journal of Laws No. 99, item 1001, consolidated text. Journal of Laws 2017, item 1065.

Polish Act of 30 April 2004 on pre-retirement benefits, consolidated text Journal of Laws 2013, item 170 as amended.

Polish Law of 13 July 2006 on the protection of employees' claims in the event of the insolvency of the employer, consolidated text Journal of Laws 2016, item 1256 as amended.

Polish Law of 19 December 2008 on bridging pensions, consolidated text Journal of Laws 2017, item 664.

Polish Act of 3 December 2010 on the implementation of some provisions of the European Union related to equal treatment, consolidated text Journal of Laws 2016, item 1219.

Polish Act of 11 May 2012 on the amendment of the law on pensions from the Social Insurance Fund, Journal of Laws, item 637.

Polish Law of 11 October 2013 on special solutions related to the protection of jobs, consolidated text Journal of Laws 2017, item 842.

Polish Act of 14 March 2014 amending the Act on promotion of employment and labour market institutions and amending certain other Acts, Journal of Laws, item 598. 
Polish Act of July 24, 2015 on the Council for Social Dialogue and other institutions for social dialogue, Journal of Laws, item 1240 as amended.

Polish of 16 November 2016 on the amendment of the law on pensions from the Social Insurance Fund and some other acts, Journal of Laws 2017, item 38.

Polish Regulation of the Minister of Labor and Social Policy of 26 January 1990 on early retirement of employees dismissed from work for reasons related to the establishment, Journal of Laws No. 4, item 27.

Polish Regulation of the Minister of Health and Welfare of 30 May 1996 on medical examinations of employees, the scope of employee preventive health care, and medical diagnoses issued for the purposes stated in the Labour Code, consolidated text Journal of Laws 2016, item 2067.

Polish Regulation of the Council of Ministers of 25 March 1997 on the principles of early retirement of employees dismissed from work for reasons related to the employer, Journal of Laws No. 29, item 159.

Polish Regulation of the Minister of Labor and Social Policy of 14 May 2014 on the allocation of funds from the National Training Fund, Journal of Laws, item 639 as amended.

Polish Resolution of the Council of Ministers of 17 October 2008, http://www.mpips.gov.pl/bip/ akty-prawne/programy/program-solidarnosc-pokolen-dzialania-dla-zwiekszenia-aktywnoscizawodowej-osob-w-wieku-50/, (accessed: 27.06.2017).

Polish Resolution of the Council of Ministers No. 16 of February 5, 2013 on the adoption of the LongTerm National Development Strategy POLSKA 2030. Trzecia Fala Nowoczesności, Ministry of Labour, item 121.

Polish Resolution of the Council of Ministers No. 238 of 24 December 2013 on the adoption of the Long-term Senior Policy in Poland for the years 2014-2020, Ministry of Labour 2014, item 118.

Polish Resolution of the Council of Ministers No. 239 of 24 December 2013 on the setting up of the Solidarity of generations program. Działania na rzecz zwiększenia aktywności zawodowej osób w wieku 50+, Ministry of Labour 2014, item 115.

Polish Resolution of the Council of Ministers No. 239 of 24 December 2013 on the setting up of the Solidarity of generations program. Działania na rzecz zwiększenia aktywności zawodowej osób w wieku 50+, Ministry of Labour 2014, item 52.

Slovak Labour Code (Zákonník práce) of 2 July 2001 (No. 311/2000), as amended.Slovak Law on Employment Services (Zákon o službách zamestnanosti) of 4 December 2003 (No. 5/2004).

Slovak Law on Old-age Pension Savings (Zákon o starobnom dôchodkovom sporení) of 10 January 2004 (No. 43/2004).

Slovak Law on Equal Treatment in Certain Areas and Protection against Discrimination, and on amending and supplementing certain other laws as amended (Antidiscrimination Act) of 20 May 2004 (No. 365/2004), as amended.

Slovak Law on Social assistance and services (Zákon o sociálnych sluzbách) of 30 October 2008 (No 448/2008), as amended.

Slovak Law on Lifelong Learning of 1 December 2009 (No. 568/2009).

Slovak Law on Health Insurance (Zákon o zdravotnom poistení) of 1 November 2011 (No. 580/2004), valid since January 2017. 
Slovak Law on Assistance in Material Need (Zákon o pomoci v hmotnej núdzi a o zmene a doplnení niektorých zákonov) of 26 November 2013 (No. 417/2013), effective on July 2014.

\section{List of judgments}

Judgment of the Court of Justice of the European Union of 12 October 2010 in Case C499/08, Collection of Judgments 2010 I-09343.

Judgment of the Belgian Constitutional Court of 7 July 2011, Arrêt n ${ }^{\circ}$ 125/2011 du 7 juillet 2011, http://www.const-court.be/public/f/2011/2011-125f.pdf, (accessed: 29.04.2016).

\section{Bibliography}

Albanese A., Cockx B. (2015), Permanent Wage Cost Subsidies for Older Workers: An Effective Tool for Increase Working Time and Postponing Early Retirement?, "IZA Discussion Paper", April, no. 8988 .

Albert F. (2015), Public Works in Hungary: an Efficient Active Labour Market Tool?, European Social Policy Network - Flash report 35, European Commission, Brussels.

Andel R. (2014), Aging in the Czech Republic, "The Gerontologist”, vol. 54, no. 6, https://academic. oup.com/gerontologist/article/54/6/893/565685/Aging-in-the-Czech-Republic.

Andersen R. V., Petersen M. V., Fries-Tersch E. (2016), Safer and Healthier Work at Any age. Country Inventory: Denmark, Bilbao.

Andersen T. M. (2012), A Flexicurity Labour Market in the Great Recession: The Case of Denmark, "De Economist", no. 160.

Barancová H., Olšovská A. (2014), Labour Law in the Slovak Republic, 2 ed., The Netherlands.

Barslund M. (2013), National Report for Denmark. Mobilising the Potential of Active Ageing in Europe (MoPAct), Brussels.

Bernais J. (1996), Klasyfikacja metod i środków przeciwdziałania bezrobociu, "Rynek Pracy” no. 4.

Bisom-Rapp S. and Sergeant M. (2016), Lifetime Disadvantage, Discrimination and the Gendered Workforce, Cambridge.

Blackham A. (2016), Extending Working Life for Older Workers, Oxford-Portland, Oregon.

Błaszczyk B. (2016), Sytuacja osób starszych na rynku pracy w Polsce, "Gerontologia Polska”, no. 24, available at: http://gerontologia.org.pl/wp-content/uploads/2016/05/Gerontologia-Polska_1_2016.pdf, (accessed: September 2017).

Błędowski P., Szatur-Jaworska B., Szweda-Lewandowska Z., Kubicki P. (2012), Report on the situation of older in Poland, Warszawa, available at: http://senior.gov.pl/source/raport_osoby\%20starsze. pdf, (accessed: September 2017).

Błędowski P., Szweda-Lewandowska Z. (2016), Polityka wobec starości i starzenia się w Polsce w latach 2015-2035. Aspekty teoretyczne i praktyczne, Warszawa. 
Bodis L. (2012), The Quality of Policy Making, [in:] K. Fazekas, A Scharle. (eds.), From Pensions to Public Employment. Hungarian Employment Policy from 1990 to 2010, Budapest.

Bördös K. (2015), Public work programmes in Hungary, [in:] K. Fazekas, J. Varga (eds.), The Hungarian Labour Market 2015, Budapest.

Brazienė R., Mikutavičienė I., Dorelaitienė A., Žalkauskaitė U., Jurkevičienė J. (2014), Vyresnio amžiaus žmonių (socialinès ịtraukites) ị(si)traukimo ị darbo rinką galimybių atsakaita.

Büchring T. (2014), Denmark: New Reform Targets Unemployment, Dublin, http://www.eurofound. europa.eu/observatories/eurwork/articles/labour-market-social-policies/denmark-new-reformtargets-unemployment, (accessed: 14.09.2016).

Buiskool B.-J., Broek S. (2016), Dente for Policy Department A: Economy and Scientific Policy, The Social and Employment Situation in the Netherlands and Outlook on the Dutch EU Presidency 2016, European Parliament, PE 563.473, available at: http://www.europarl.europa.eu/RegData/etudes/ BRIE/2015/563473/IPOL_BRI(2015)563473_EN.pdf, (accessed: September 2017).

Bundesagentur für Arbeit (2012): Host Country PES Issues Paper, Peer Review 'PES and Older Workers', The European Commission Mutual Learning Programme for Public Employment Services, European Commission March, Brussels.

Burokaitė G. (2014), Pagyvene zmones Lietiuvoje, Gyventojai ir socialinè statistika, Socialinè apsauga. Gyventojai ir socialinè statistika. Socialinè apsauga, Lietuvos statistikos departamentas, Vilnius (December), http://ec.europa.eu/eurostat/web/ess/-/older-people-in-lithuania, (accessed: September 2017).

Clauwaert S. and Schömann I. (2013), The Crisis and National Labour Law Reforms: a Mapping Exercise, Country report: Czech Republic, Last update: January, https://www.etui.org/.../ Czech+Republic+january+2013+WTC.pdf, (accessed: September 2017).

Communication from the Commission (2010), An Agenda for New Skills and Jobs: A European Contribution towards Full Employment', Strasbourg 23.11.2010, COM (2010) 682 final, available at: http://eur-lex.europa.eu/LexUriServ/LexUriServ.do?uri= COM:2010:0682:FIN:EN:PDF, (accessed: September 2017).

Contreras N., Martelucci E., Thum A.-E. (2014), Active Ageing in Belgium, Mobilising the Potential of Active Ageing in Europe (MoPAct), Country Report.

Council of the European Union, Recommendation on the 2016 National Reform Programme of Poland and Delivering a Council Opinion on the 2016 Convergence Programme of Poland, available at: http://ec.europa.eu/europe2020/making-it-happen/country-specific-recommendations/index_pl.htm (accessed: 1.02.2017).

Crizia L. (Institute for Labour and Family Research) (2013), Governments Schemes Support Employment, available at: https://www.eurofound.europa.eu/observatories/eurwork/articles/government-schemes-support-employment (accessed: 7.04.2013).

Crizia L. (Institute for Labour and Family Research) (2013), Slovakia: The Role of the Governments and Social Partners in Keeping Older Workers in the Labour Market, available at: https://www. eurofound.europa.eu/observatories/eurwork/comparative-information/role-of-governmentsand-social-partners-in-keeping-older-workers-in-the-labour-market. (accessed: 2.06.2013).

Cseres-Gergely Z. (2012), Hungary, EEO Review, Employment Policies to Promote Active Ageing, European Employment Observatory, European Commission, Brussels. 
Cseres-Gergely Z., Varadovics K. (2014), Labour Market policy Interventions September 2012-January 2014, [in:] K. Fazekas, L. Neumann (eds.), The Hungarian Labour Market 2014, Budapest.

Czapiński J., Błędowski P. (2014), Aktywność społeczna osób starszych w kontekście percepcji Polaków. Diagnoza społeczna 2013, Warszawa, http://www.diagnoza.com/pliki/raporty_tematyczne/Aktywnosc_spoleczna_osob_starszych.pdf, (accessed: September 2017).

Czech Social Security Administration, Old-age pension, available at: http://www.cssz.cz/en/pensioninsurance/old-age-pension.htm, (accessed: September 2017).

Dejemeppe M., Smith C., Van der Linden B. (2015), Did the Intergenerational Solidarity Pact Increase the Employment Rate of Older Workers in Belgium? A Macro-Econometrics Evaluation, "IZA Discussion Paper", June, no. 9115.

Devisscher S. (2004), The Career Break (Time Credit) Scheme in Belgium and the Incentive Premiums by the Flemish Government, Peer Review 19-20 February, Mutual Learning Programme (MLP) under the European Employment Strategy, http://pdf.mutual-learning-employment.net/pdf/ belgium\%2004/Discussion\%20paperBEL04.pdf, (accessed: 28.04.2016).

EAEA (2011): Country report Slovakia (Helsinki), www.eaea.org/country/slovakia, available at: http://www.eaea.org/media/resources/ae-in-europe/slovakia_country-report-on-adult-education-in-slovakia.pdf. (accessed: 1.06.2017).

Ebbinghaus B., Eichhorst W. (2006), Employment Regulation and Labour Market Policy in Germany, 1991-2005, “IZA Discussion Paper”, December, no. 2502.

ENCC (2017), European Monitoring Centre on Change, Slovakia: Notice Period for Employees, available at: https://www.eurofound.europa.eu/observatories/emcc/erm/legislation/slovakia-noticeperiod-to-employees. (accessed:6.07.2017).

ETUI (2017), News, Netherlands: Marked Increase in Flexible Workers, 10 April, available at: https:// www.etui.org/News/Netherlands-marked-increase-in-flexible-workers, (accessed: September 2017).

EUROFOUND (2009), Protection against Dismissal: Germany, http://www.eurofound.europa.eu/ efemiredictionary/protection-against-dismissal-1, (accessed: 13.07.2016).

European Centre for the Development of Vocational Training (CEDEFOP) (2012), Vocational Education and Training in Denmark. Short Description, Luxembourg.

European Commission (2010), Communication from the Commission, Europe 2020, A Strategy for Smart, Sustainable and Inclusive Growth, Brussels, 3.3.2010 com(2010) 2020, available at: http:// ec.europa.eu/eu2020/pdf/complet\%20en\%20barroso\%20\%20\%20007\%20-\%20europe\%20 2020\%20-\%20en\%20version.pdf, (accessed: September 2017).

European Commission (2011), Age and Employment, as of July, available at https: //www.age_and_ employmen_en.pdf, (accessed: September 2017).

European Commission (2012), Belgium - Unemployment, Employment, Social Affairs \& Inclusion, http://ec.europa.eu/social/main.jsp?catId=1102\&langId=en\&intPageId=4425, (accessed: September 2017).

European Commission (2014), The 2015 Ageing Report, European Commission, European Economy, no. 8, UE 2014, http://ec.europa.eu/economy_finance/publications/european_economy/2014/ pdf/ee8_en.pdf.

European Commission (2015), Brussels, COM (217) 518 final, Recommendation for a Council Recommendation on the 2017 National Reform Programme of the Netherlands and Delivering a Council 
Opinion on the 2017 Stability Programme of the Netherlands, available at: https://ec.europa.eu/ info/sites/info/files/2017-european-semester-country-specific-recommendations-commissionrecommendations_-_netherlands.pdf, (accessed: September 2017).

European Commission (2015), Education and Training Monitor 2015: Slovakia, available at: http:// ec.europa.eu/dgs/education_culture/repository/education/tools/docs/2015/monitor2015-slovakia_en.pdf, (accessed: September 2017).

European Commission (2015), The 2015 Ageing Report, "European Economy", no. 3, Economic and Financial Affairs, Economic and budgetary projections for the 28 EU Member States, Luxembourg, available at: http://ec.europa.eu/economy_finance/publications/european_economy/2015/pdf/ee3_en.pdf, (accessed: September 2017).

European Commission (2016), Education and Training Monitor, Netherlands, as of 15 September 2016, available at: https://ec.europa.eu/education/sites/education/files/monitor2016-nl_en.pdf (accessed:15.09.2016).

European Commission (2017), Commission Staff Working Document, Country Report, The Netherlands 2017: Including an In-depth Review on the Prevention and Correction of Macroeconomic Imbalances, Brussels, 22.2.2017, SWD 84 final, p. 50, available at: https://ec.europa.eu/info/sites/ info/files/2017-european-semester-country-report-netherlands-en.pdf, (accessed: September 2017).

European Employment Observatory Review (2012), Employment Policies to Promote Active Ageing 2012, Luxemburg:, L. Vagač (Centre for Economic Development), Slovakia, available at: https:// www.ifa-fiv.org/wp-content/uploads/2015/03/6-EU-Active-Ageing-2012.pdf, (accessed: September 2017).

Eurostat News release (2015), Employment Rates for the Age Group 55-64, Europe 2020 Employment Indicators, no. 81 - 7 May, available at: http://ec.europa.eu/eurostat/documents/2995521/6823708/307052015-AP-EN.pdf/7e507ea0-43c7-452f-8e6a-b479c89d2bd6, (accessed: September 2017).

Fazekas K., Scharle A. (2012), Diagnosis and Lessons, [in:] K. Fazekas, A. Scharle (eds.), From Pensions to Public Works. Hungarian Employment Policy from 1990 to 2010, Budapest.

Filges T., Larsen M., Pedersen P. J. (2012), Retirement: Does Individual Unemployment Matter? Evidence from Danish Panel Data 1980-2009, “IZA Discussion Paper”, May, no. 6538, Bonn.

Frey M. (2010), The Legal and Institutional Environment of the Hungarian Labour market, [in:] K. Fazekas, A. Lovasz, A. Telegdy (eds.), The Hungarian Labour Market. Review and Analysis 2010, Budapest.

Galli C. da Bino and Blomsma M. (2017), Netherlands: Latest Working Life Developments - Q2 2017, https://www.eurofound.europa.eu/en/observatories/eurwork/articles/netherlands-latest-working-life-developments-q2-2017 (accessed: 2.08.2017).

Garlicki L., Zubik M. (2016), Komentarz do art. 20, [in:] Konstytucja Rzeczypospolitej Polskiej. Komentarz. vol I, ed. II, [online], Warszawa, https://sip.lex.pl/\#/komentarz/587734548/531988, (accessed: 27.07.2017).

German Federal Ministry of Labour and Social Affairs (2015), Social Security at a Glance 2015, Referat Information, Bonn.

Główny Urząd Statystyczny (2015), Związki zawodowe w Polsce w 2014 r. Notatka informacyjna, Warszawa.

Główny Urząd Statystyczny (2017), Persons over 50 on the Labor Market in 2015, Warszawa-Bydgoszcz. 
Góral Z. (2002), Dyferencjacja statusu prawnego bezrobotnych, [in:] M. Matey-Tyrowicz, L. Nawacki,

B. Wagner (eds.), Prawo pracy a wyzwania XXI-go wieku: księga jubileuszowa Profesora T. Zielińskiego, Warszawa.

Góral Z. (2004), Komentarz do art. 19 ustawy o zatrudnieniu i przeciwdziałaniu bezrobociu, [in:] Z. Salwa (ed.) Prawo pracy, Warszawa.

Góral Z. (ed.), (2011), Ustawa o promocji zatrudnienia i instytucjach rynku pracy. Praktyczny komentarz, ed. I, Warszawa.

Góral Z. (ed.), (2016), Ustawa o promocji zatrudnienia i instytucjach rynku pracy. Komentarz, ed. II, Warszawa.

Góral Z., Włodarczyk M. (1992), Komentarz do art. 21, [in:] Komentarz do ustawy z dnia 16 października 1991 r. o zatrudnieniu i bezrobociu, Łódź.

Góral Z., Włodarczyk M. (1997), Prawne problemy rynku pracy, [in:] H. Lewandowski (ed.), Polskie prawo w okresie transformacji w oświetleniu prawa wspólnotowego, Warszawa.

Goździewicz G. (1997), Wplyw działań zbiorowych na indywidualne stosunki pracy, [in:] H. Lewandowski (ed.), Polskie prawo pracy w okresie transformacji w oświetleniu prawa wspólnotowego, Warszawa.

Graversen B. K., van Ours J.C. (2006), How to Help Unemployed Find Jobs Quickly: Experimental Evidence from a Mandatory Activation Program, "IZA Discussion Paper", December, no. 2504.

Gundt N. (2016), The Protection of Unemployed Persons in the Netherlands, [in:] T. Bazzani, R. Singer (eds.), Security in the EU. An Overview of the Passive and Active Labour Market Policies in the Netherlands, Poland, Italy, Spain and Greece.

Haan P., Steiner V. (2006), Making Work Pay for the Elderly Unemployed: Evaluating Alternative Policy Reforms for Germany, “IZA Discussion Paper”, November, no. 2424.

Hála J. (2013), Czech Republic: The Role of Governments and Social Partners in Keeping Older Workers in the Labor Market, https://www.eurofound.europa.eu/observatories/eurwork/comparativeinformation/national-contributions/czech-republic/czech-republic-the-role-of-governmentsand-social-partners-in-keeping-older-workers-in-the-labour (accessed: 2.06.2013).

Halásková M., Halásková R., Slavata M. (2012), Concept of Flexicurity in the Conditions of Labour Market of the Czech Republic, [in:] K. Lordoğlu, D. Keskin Demirer, İ. Şiriner (eds.), Labour Markets and Employment, London, available at: https://books.google.pl/books?id=WN0nMB6_3_ gC\&pg=PA149\&lpg=PA149\&dq=disadvantaged +groups+in+CZech+labour+market\&source $=$ bl\&ots=7kSlJPK4bh\&sig=vgNGibQetpwrjD_d8jTBp26p_i8\&hl=pl\&sa=X\&ved=0ahUKEwjxr_ HwpszVAhUGKIAKHTG5DlEQ6AEIQDAD\#v=onepage\&q=disadvantaged\%20groups\%20 in\%20CZech\%20labour\%20market\&f=false, (accessed: September 2017).

Hermans V., Motmans R., Himpens A. (2010), The Professional Experience Fund - a Belgian Example for Support of the Quality of Work for Elderly Workers, Proceedings of the European Conference on Ergonomics, Brussels

Heywood J. S., Jirjahn U. (2015), The German Labor Market for Older Workers in Comparative Perspective, "Research Paper in Economics", no. 2.

Hochmeyer K. (2009), Effectiveness of One-Euro-Jobs. Do programme characteristics matter?, "IAB Discussion Paper" 2009, no. 20.

ILO, Decent Work and the 2030 Agenda for Sustainable Development, available at: http://www.ilo. org/global/topics/sdg-2030/lang--en/index.htm, (accessed: September 2017). 
Jaworska K. (2014), Standardy Międzynarodowej Organizacji Pracy i Rady Europy a polski system zabezpieczenia społecznego na wypadek bezrobocia, "Studia Prawnoustrojowe", no. 24.

Jensen P. H. (2005), Reversing the Trend from "Early" to "Late" Exit: Push, Pull, and Jump Revisited in a Danish Context, "The Geneva Papers on Risk and Insurance - Issues and Practice”, vol. 30. Jensen P. H. (2007), Employment and Labour Market Policies for an Ageing Workforce and Initiatives at the Workplace, National Overwiev Report: Denmark, Dublin.

Jensen V., Lundager B., Christensen A. L., Fonager K. (2014), Unemployment Under the Flex Job Scheme Increases the Risk of Permanent Social Security Benefits, "Danish Medical Journal”, April. Jørgensen C. (2009), Denmark: Collective Bargaining and Continuous Vocational Training, Dublin, http://www.eurofound.europa.eu/observatories/eurwork/comparative-information/nationalcontributions/denmark/denmark-collective-bargaining-and-continuous-vocational-training, (accessed: 29.09.2016).

Jørgensen C. (2013), Denmark: The Role of Governments and Social Partners in Keeping Older Workers in the Labour Market, Dublin, http://www.eurofound.europa.eu/observatories/eurwork/ comparative-information/national-contributions/denmark/denmark-the-role-of-governmentsand-social-partners-in-keeping-older-workers-in-the-labour-market, (accessed: 21.07.2016).

Kabaj M. (1997), Strategie i programy przeciwdziałania bezrobociu. Studium porównawcze, Warszawa.

Kahancová M., Sedláková M. (Central European Labor Studies Institute, Eurofund) (2015), New Forms of Employment. Job Sharing and Casual Work, Slovakia, Case study 41: Policy analysis, available at: https://www.eurofound.europa.eu/sites/default/files/page/field_ef_documents/41_-_ef1461_-_sk-job_sharing_and_casual_work_-_final.pdf, (accessed: September 2017).

Kahanec M., Sedláková M. (2016), Social and Employment Situation in Slovakia and Outlook of the Slovak EU Presidency 2016, May 2016, available at: http://www.europarl.europa.eu/RegData/etudes/STUD/2016/578982/IPOL_STU(2016)578982_EN.pdf, (accessed: September 2017).

Kemmerling A., Bruttel O. (2005), New Politics in German Market Policy? The Implications of the Recent Hartz Reforms for the German Welfare State, "Wissenschaftszentrum Berlin für Sozialforschung (WZB) Discussion Paper", February.

Keune M. (2011), Sector-level Bargaining and Possibilities for Deviations at Company Level: Belgium, Dublin, http://www.eurofound.europa.eu/publications/report/2011/belgium/industrial-relations/sector-level-bargaining-and-possibilities-for-deviations-at-company-level-belgium, (accessed: 8.04.2016).

Kisiel R., Nowińska S. (2010), Efektywność aktywnej polityki rynku pracy na tle doświadczeń międzynarodowych, "Polityka Społeczna", no. 5-6.

Kiss A. (2015), Hungary: Bleak Prospects for Public Sector Workers under Economic Programme, Dublin, https://www.eurofound.europa.eu/observatories/eurwork/articles/working-conditions/ hungary-bleak-prospects-for-public-sector-workers-under-economic-programme, (accessed: 19.06.2017).

Kiss A., Belyó P., Kunert A., Komiljovics M., György K. (2015), Hungary: Working Life Country Profile, Dublin, https://www.eurofound.europa.eu/observatories/eurwork/comparative-information/national-contributions/hungary/hungary-working-life-country-profile, (accessed: 9.06.2017). 
Kiss Z., Balogh K. (2007), Increasing Reliance on Older Workers in the Labour Market, Dublin, https://www.eurofound.europa.eu/ga/observatories/eurwork/articles/other/increasing-reliance-on-older-workers-in-the-labour-market, (accessed: 7.06.2017).

Knapińska M. (2010), Polityka rynku pracy w Polsce w latach 2000-2008, [in:] E. Kwiatkowski, L. Kucharski (eds.), Rynek pracyw Polsce - tendencje, uwarunkowania i polityka państwa, Łódź.

Kollo J. (2012), Minimum Wage Regulation, [in:] K. Fazekas, A. Scharle (eds.), From Pensions to Public Works. Hungarian Employment Policy from 1990 to 2010, Budapest.

Kollo J., Scharle A. (2012), The Impact of the Expansion of Public Work Programs on Long-term Unemployment, [in:] Fazekas K., Kezdi G. (eds.), The Hungarian Labour Market 2012. In Focus: the Evaluation of Active Labour Market Programs, Budapest.

Kołodziejczyk-Olczak I. (2014), Zarządzanie wiekiem a polityka wspierania starszych pracowników. Doświadczenia polskie na tle innych krajów, “Studia Demograficzne”, vol. 2 (166).

Kordošová M. (Institute for Labour and Family Research) (2014), Unfair Treatment of Older People in The Labour Market, available at: https://www.eurofound.europa.eu/observatories/eurwork/ articles/unfair-treatment-of-older-people-in-the-labour-market (accessed: 22.04.2014).

Kraemer B. (2015), Germany: Working Life Country Profile, Dublin, http://www.eurofound.europa. eu/observatories/eurwork/comparative-information/national-contributions/germany/germany-working-life-country-profile, (accessed: 18.06.2016).

Kryńska E. (ed.), (2013), Elastyczne formy zatrudnienia i organizacji pracy a aktywność zawodowa osób starszych. Raport syntetyczny w ramach projektu: Badanie wplywu elastycznych form zatrudnienia i organizacji pracy na aktywność zawodową zasobów pracy w wieku 45+, Warszawa.

Kryńska E., Krzyszkowski J., Urbaniak B. (2013), Wnioski generalne, [in:] E. Kryńska, J. Krzyszkowski, B. Urbaniak, J. Wiktorowicz (eds.), Diagnoza obecnej sytuacji kobiet i mężczyzn 50+ na runku pracy w Polsce. Raport końcowy, Łódź.

Kryńska E., Kukulak-Dolata I., Poliwczak I., Wojtaszczyk K. (2013), Perspektywa instytucji rynku pracy, [in:] E. Kryńska, J. Krzyszkowski, B. Urbaniak, J. Wiktorowicz (eds.), Diagnoza obecnej sytuacji kobiet i mężczyzn 50+ na rynku pracy w Polsce. Raport końcowy, Łódź.

Kryńska E., Kukulak-Dolata I., Poliwczak I., Wojtaszczyk K., (2013), Wsparcie oferowane przez instytucje rynku pracy, [in:] E. Kryńska, J. Krzyszkowski, B. Urbaniak, J. Wiktorowicz (eds.), Diagnoza obecnej sytuacji kobiet i mężczyzn 50+ na runku pracy w Polsce. Raport końcowy, Łódź.

Kryńska E., Szukalski P. (ed.), (2013), Rozwiązania sprzyjające aktywnemu starzeniu się w wybranych krajach Unii Europejskiej. Raport końcowy, Łódź.

Kwiatkowski E. (2010), Kluczowe wyzwania dla polskiego rynku pracy, [in:] E. Kwiatkowski, L. Kucharski (eds.), Rynek pracyw Polsce - tendencje, uwarunkowania i polityka państwa, Łódź. Kwiatkowski E. (2014), Bezrobocie. Podstawy teoretyczne, Warszawa.

Lauzadyte A. (2007), Unemployment. Employment and Inactivity in Denmark: An Analysis of event History Data, "Economics Working Papers", no. 18.

Lehoczky C. K. (2010), Legal Instruments Guaranteeing Equal Treatment in the Wake of Accession to the European Union, [in:] K. Fazekas, A. Lovasz, A. Telegdy (eds.), The Hungarian Labour Market 2010. Review and Analysis, Budapest.

Lengvinienė S., Rutkienė A., Tandzegolskienė I. (2014), Vyresnio amžiaus asmenų išlikimo darbo rinkoje teoriniai aspektami, Profesinis rengimas: tyrimai ir realijos no. 25, www.ejournals.vdu. lt/index.php/vocationaltraining/.../250, (accessed: January 2016). 
Leschke J., Schmid G., Griga D. (2006), On the Marriage of Flexibility and Security: Lessons from the Hartz-reforms in Germany, "Wissenschaftszentrum Berlin für Sozialforschung (WZB) Discussion Paper", April.

Lietuvos Darbo Birza, ESF projektas “Vyresnio amžiaus bedarbių rėmimas” https://www.ldb.lt/Informacija/ESParama/Puslapiai/vyresnio_amziaus_bed_remimas.aspx.

Lietuvos Darbo Birza, Projektas "Ilgalaikių bedarbių įdarbinimo remimas", https://www.ldb.lt/Informacija/ESParama/Puslapiai/esf_ilgalaik_bedarb_remimas.aspx, (retrieved on January 2016).

Lietuvos Darbo Birza, Projektas “Pagalba ịsidarbinant”, https://www.ldb.lt/Informacija/ESParama/ gyvendinti\%20ES\%20projektai/UserDispForm.aspx?ID=29, (accessed: January 2016).

Lietuvos Respublikos Socialinès Apsaugos ir Darbo Ministro įsakymas Dèl aktyvios darbo rinkos politikos priemoniu igyvendinimo sąlygų ir tvarkos aprašo patvirtinimo $2009 \mathrm{~m}$. rugpjūčio 13 d., Nr. A1-499, http://www3.lrs.lt/pls/inter3/dokpaieska.showdoc_l?p_id=350927\&p_ query=\&p_tr2, (accessed: January 2016).

Lipták K. (2013), Hungary: The Role of Governments and Social Partners in Keeping Older Workers in the Labour Market, Dublin, https://www.eurofound.europa.eu/observatories/eurwork/comparative-information/national-contributions/hungary/hungary-the-role-of-governments-andsocial-partners-in-keeping-older-workers-in-the-labour-market, (accessed: 7.06.2017);

Lovens P.-F. (2002), Agreement on Outplacement for Older Workers, Dublin, http://www.eurofound. europa.eu/observatories/eurwork/articles/agreement-on-outplacement-for-older-workers, (accessed: 8.04.2016).

Madsen P. K. (2012), EEO Review: Employment Policies to Promote Active Ageing: Denmark, European Employment Observatory, European Commission. Brussels

Madsen S. H. (2009), Denmark, [in:] N. ten Bokum, R. Sands, R. von Steinau-Steinrück (eds.), Age Discrimination Law in Europe, The Netherlands.

Mažionienė D., Valeckienè, I. Mažionytė, D. Beržinytė, T. Aleksandravičiutė, D. Bliudžiutė, R. Razmutè, K. Zakarauskaitè (2011), Ageing in Lithuania, Klaipeda, http://www.mep_activeageing.ipleiria.pt/files/2012/01/Klaipeda-State-College1.pdf, (accessed: January 2016).

Meyer T., Bridgen P., Riedmüller B. (eds.), (2007), Private Pensions Versus Social Inclusion? Non-state Provision for Citisiens in Europe, Cheltenham, UK-Northampton, Massachusetts, USA.

Ministerstwo Pracy i Polityki Społecznej (2008), Program 45/50 Plus, Program działań na rzecz promocji zatrudnienia, łagodzenia skutków bezrobocia i aktywizacji zawodowej osób w wieku niemobilnym, Warszawa, http://psz.praca.gov.pl/documents/10828/182467/Program\%2045-50\%20 PLUS.pdf/6a7ead58-71ca-46e5-bac7-49901c557cc9?t=1403859201000, (accessed: 28.06.2017).

Ministerstwo Rodziny, Pracy i Polityki Społecznej - Departament Rynku Pracy (2015), Warunki życia i pracy w krajach Europejskiego Obszaru Gospodarczego, Litwa, www.eures.praca.gov.pl/ zal/warunki_zycia/litwa/litwa.pdf, (accessed: January 2016).

Ministry of Labour and Social Affairs, Old-age Pension, available at: http://www.mpsv.cz/en/12954. MISSOC (2013), Your Social Security Rights in Hungary, European Commission. Brussels

MISSOC, Comparative Tables in Social Protection, Czech Republic: Old-age, http://www.missoc.org/ MISSOC/INFORMATIONBASE/COMPARATIVETABLES/MISSOCDATABASE/comparativeTablesSearchResultTree.jsp Massachusetts 
MISSOC, Comparative Tables on Social Protection - Results, Old-age Pension, The Netherlands, available at: http://www.missoc.org/MISSOC/INFORMATIONBASE/COMPARATIVETABLES/MISSOCDATABASE/comparativeTablesSearchResultTree.jsp. (accessed: 1.01.2017).

MISSOC, Comparative Tables on Social Protection Results, Old-age Pension, Slovakia, available at: http://www.missoc.org/MISSOC/INFORMATIONBASE/COMPARATIVETABLES/MISSOCDATABASE/comparativeTablesSearchResultTree.jsp, (accessed: September 2017).

MISSOC, Comparative Tables on Social Protection Results, Unemployment, Slovakia, available at: http://www.missoc.org/MISSOC/INFORMATIONBASE/COMPARATIVETABLES/MISSOCDATABASE/comparativeTablesSearchResultTree.jsp, (accessed: September 2017).

MISSOC, Comparative Tables on Social Protection, Unemployment, Lithuania, available at: http:// www.missoc.org/MISSOC/INFORMATIONBASE/COMPARATIVETABLES/MISSOCDATABASE/comparativeTablesSearchResultTree.jsp. (accessed: 1.01.2017).

MISSOC, Comparative Tables on Social Protection, Unemployment, Netherlands, available at http:// missoc.org/MISSOC/INFORMATIONBASE/COMPARATIVETABLES/MISSOCDATABASE/ comparativeTablesSearchResultTree.jsp, (accessed: September 2017).

MISSOC, Comparative Tables, Germany, http://www.missoc.org/MISSOC/INFORMATIONBASE/ COMPARATIVETABLES/MISSOCDATABASE/comparativeTablesSearchResultTree.jsp, (accessed: 1.07.2016)

MISSOC, Comparative Tables, Hungary, http://www.missoc.org/MISSOC/INFORMATIONBASE/COMPARATIVETABLES/MISSOCDATABASE/comparativeTableSearch.jsp, (accessed: 1.07.2016).

Nacsa B. (2008), Fixed-term Contracts in Law on Paper and in Practice. Remarks to the Flexicurity Debate, "Annales Universitatis Scientiarium Budapestinensis de Rolando Eötvös Nominatae Sectio Iuridica”, vol. XLIX, http://www.ajk.elte.hu/file/annales_2008_15_Nacsa.pdf, (accessed: 19.06.2017).

Navaitis G., Burneikienė A., Trinkūnienė R. (2008), Lygiu galimybiu pažeidimai (amžiaus aspektas), “Socialinis Darbas”, no. 7 (3), https://www.mruni.eu/upload/iblock/5b7 /5_navaitis_burneikiene_trinkuniene.pdf, (accessed: January 2016).

Nyklewicz K. (2010), Nowa strategia aktywizacji bezrobotnych w Niemczech, "Polityka Społeczna", no. 2.

OECD (2012), Thematic Follow-Up for Review of Policies to Improve Labour Market Prospects for Older Workers, Czech Republic (Situation mid-2012), available at: OECD, Ageing and Employment Policies. Working Better With Age, Paris 2015.

OECD (2012), Thematic Follow-up Review of Policies to Improve Prospects of Labour Market Situation of Older Workers, Denmark, Paris.

OECD (2012), Thematic Follow-Up, Review of Policies to Improve Labour Market Prospects for Older Workers, Germany (Situation mid-2012), Paris.

OECD (2013), Detailed Description of Employment Protection Legislation 2012-2013, Denmark, Employment Protection Database.

OECD (2013), Detailed Description of Employment Protection Legislation 2012-2013, Hungary, OECD EPL Database.

OECD (2014), Working Better with Age, Netherlands, Assessment and Main Recommendations, Directorate for Employment, Labour and Social Affairs, April 2014, p. 1, available at: https://www. 
oecd.org/els/emp/Older\%20Workers\%20NETHERLANDS_Assessment\%20and\%20main\%20 recommendations.pdf.

OECD (2015), Ageing and Employment Policies: Denmark 2015: Working Better With Age, Paris.

OECD (2015), Assessment and Key Recommendations - Working Better with Age in Denmark, Paris.

OECD (2015), Pensions at a Glance 2015: Country Profiles - Slovak Republic, Paris, DOI: http:// dx.doi.org/10.1787/pension_glance-2015-75-en, (accessed: September 2017).

OECD (2016), Economic Surveys: Hungary, Paris.

OECD (2017), Labour Force Statistics 2016, Czech Republic, Paris, http://www.keepeek.com/DigitalAsset-Management/oecd/employment/oecd-labour-force-statistics-2016/czech-republic_oecd_ lfs-2016-8-en\#.WWCg9Lgso7Q\#page1, (accessed: September 2017).

OECD insights (2015), Debate the Issue: Health Systems are Still Not Prepared for an Ageing Population, available at: http://oecdinsights.org/2015/04/29/health-systems-are-still-not-prepared-foran-ageing-population/ (accessed: 1.06.2017).

Organiściak-Krzykowska A. (2010), Współczesne problemy polskiego rynku pracy na tle krajów UE, [in:] E. Kwiatkowski, L. Kucharski (eds.), Rynek pracy w Polsce - tendencje, uwarunkowania ipolityka państwa, Łódź.

Pacud R. (2016), Utracona sprawiedliwość międzypokoleniowa w ubezpieczeniu emerytalnym?, "Praca i Zabezpieczenie Społeczne", no. 2.

Paluszkiewicz M. (2012), Wyrównywanie szans pracowników starszych w zatrudnieniu w świetle prawa międzynarodowego a prawo polskie, "Praca i Zabezpieczenie Społeczne", no. 12.

Paluszkiewicz M. (2014), Agencje zatrudnienia po nowelizacji ustawy o promocji zatrudnienia i instytucjach rynku pracy, "Praca i Zabezpieczenie Społeczne", no. 6.

Paluszkiewicz M. (2016), Komentarz do rozdziału 13a, [in:] Z. Góral (ed.), Ustawa o promocji zatrudnienia i instytucjach rynku pracy. Komentarz, Warszawa.

Paluszkiewicz M. (2016), Komentarz do rozdziału 13b, [in:] Z. Góral (ed.), Ustawa o promocji zatrudnienia i instytucjach rynku pracy. Komentarz, Warszawa.

Paluszkiewicz M. (2016), Wybrane środki prawne wspomagające powrót bezrobotnych osób starszych na rynek pracy w Belgii, “Gdańsko-Łódzkie Roczniki Prawa Pracy i Prawa Socjalnego”, vol. 6.

Paluszkiewicz M. (2016), Wybrane środki prawne wspomagające utrzymanie zatrudnienia przez pracowników starszych w Niemczech, "Studia Prawno-Ekonomiczne", vol. CI.

Paluszkiewicz M. (2016), Wybrane środki prawne wspomagajace utrzymanie zatrudnienia pracowników starszych w Belgii, "Praca i Zabezpieczenie Społeczne”, no. 10.

Paluszkiewicz M. (2017), Wybrane środki prawne wspierające bezrobotne osoby starsze w podjęciu zatrudnienia w Niemczech, "Polityka Społeczna", no. 2.

Paluszkiewicz M. (2017), Wybrane środki prawne wspierające zatrudnienie pracowników starszych w Danii, “Zeszyty Prawnicze UKSW”, vol. 17.3.

Paluszkiewicz M. (2017), Wybrane środki prawne wspomagające powrót bezrobotnych osób starszych na rynek pracy w Danii, "Studia z Zakresu Prawa Pracy i Polityki Społecznej”, vol. 24, no. 3.

Pennings F (2013), Social Security Law in the Netherlands, The Netherlands.

Petrylaite D. (2014), Four Years of Lithuanian Labour Reforms, Lithuanian National Report, International Society for Labor and Social Security, available at: http://islssl.org/wp-content/uploads/2014/08/Lithuanian-National-Report.pdf (accessed: 1.07.2017). 
Pichrt J., Stefko M. (2015), Labor Law in the Czech Republic, [in:] R. Blanpain, F. Hendrickx (eds.), International Encyclopaedia of Laws/Labour Law and Industrial Relations, 2 ed., The Netherlands.

Podgórniak-Krzykacz A., Przywojska J., Krajowe i regionalne programy rynku pracy wobec aktywizacji zawodowej osób w wieku 50+/45+, [in:] B. Urbaniak, J. Wiktorowicz (eds.), Raport z analizy programów skierowanych do osób 50+ zrealizowanych w Polsce w latach 2004-2009, Łódź.

Program of the Polish Council of Ministers (2008), Solidarność pokoleń. Działania dla zwiększenia aktywności zawodowej osób w wieku 50+, Warszawa.

Rigo M., Vandenberghe V., Waltenberg F. (2012), Ageing and Employability. Evidence from Belgian Firm-level Data, "Institut de Recherches Économiques et Sociales (IRES) Discussion Paper”, vol. 11.

Rosholm M., Svarer M., Hammer B. (2004) , A Danish Profiling System, "IZA Discussion Paper”, November, no. 1418.

Rosholm M., Svarer M., Pedersen J. M. (2012), Why is Unemployment so Low in Denmark?, Evidence from Four Social Experiments, Paper presented at the EEA-ESEM 2012 Conference, https:// www.empiwifo.uni-freiburg.de/lehre-teaching-1/winter-term-12-13/Mat-Microeco/Lecture/ rosholm_dp_12, (accessed: 26.07.2016).

Sanetra W. (1993), Komentarz do art. 21, [in:] Zatrudnienie i bezrobocie. Przepisy i komentarz, Warszawa.

Scharle A. (2012), Activation and wage adjustments, [in:] K. Fazekas, A. Scharle (eds.), From pensions to public works. Hungarian employment policy from 1990 to 2010, Budapest.

Scharle A. (2016), Labour Market Policy Tools (May 2015-March 2016), [in:] Z. Blazsko, K. Fazekas (eds.), The Hungarian Labour Market 2016, Budapest.

Shilling J. (2016), Who Retires and Why? A Comparative Study Analyses of Retirement Processes on the Case Study Denmark, Bamberg, available at: https://books.google.pl/books?id=H 18SDQAAQBAJ\&pg=PA80\&lpg=PA80\&dq=Dutch + Law + on ++ Old-Age + Pensions + (Alg emene+Ouderdomswet, + AOW $)+$ of \&source=bl\&ots=PF39s34XJe\&sig=WqDcExUpkKB LRewSy319A-Pq318\&hl=pl\&sa=X\&ved=0ahUKEwj6_fLX-43XAhWMZFAKHRKBDVIQ6AE IRjAF\# $\mathrm{v}=$ onepage \&q= Dutch\%20Law\%20on\%20\%20Old-Age\%20Pensions\%20(Algemene\%20 Ouderdomswet\%2C\%20AOW)\%20of\&f=false, (accessed: September 2017).

Singer Ch., Toomet O.-S. (2013), On Ggovernment-subsidized Training Programs for Older Workers, "IAB Discussion Paper", vol. 21.

Slovak Academic Association for International Cooperation (2014), Lifelong Guidance System in Slovakia, Bratislava Euroguidance, http://web.saaic.sk/nrcg_new/kniznica/2014/EG_CounselingSystem_Slovakia.pdf.

Sobocka-Szczapa H. (ed.), Poliwczak I. (2011), Diagnoza sytuacji osób w wieku 45+ na rynku pracy w Polsce i wybranych krajach Unii Europejskiej. Aspekt ekonomiczny, Łódź.

Social Security Administration (2016), Research, Statistics, and Policy Analysis, Social Security Programs Through the World, Europe 2016 (released September), Netherlands, available on: http:// ssa.gov, (accessed: September 2017).

Sociale Verzekeringsbank, AOW Pension, available at: https://www.svb.nl/int/en/aow/wat_is_de_ aow/wanneer_aow/index.jsp.

Sodra, Senatves pensija, http://www.sodra.lt/lt/situacijos/informacija-gyventojams/noriu-gautipensija/senatves-pensija, (accessed: January 2016). 
Staszewska E. (2005), Status prawny osób bezrobotnych z grup szczególnego ryzyka, "Polityka Społeczna”, no. 1.

Staszewska E. (2010), Pojęcie "osób będących w szczególnej sytuacji na rynku pracy" w świetle ustawy o promocji zatrudnienia i instytucjach rynku pracy, "Zeszyty Prawnicze UKSW”, vol. 10.1.

Staszewska E. (2011), Komentarz do art. 50, [in:] Z. Góral (ed.), Ustawa o promocji zatrudnienia i instytucjach rynku pracy. Praktyczny komentarz, ed. I, Warszawa.

Staszewska E. (2016), Komentarz do art. 38, 49, 53, 53a-53m, 57, 59, [in:] Z. Góral (ed.), Ustawa o promocji zatrudnienia i instytucjach rynku pracy. Praktyczny komentarz, ed. II, Warszawa.

Stettes O. (2013), Germany: The Role of Governments and Social Partners in Keeping Older Workers in the Labour Market, 2 June, http://www.eurofound.europa.eu/observatories/eurwork/ comparative-information/national-contributions/germany/germany-the-role-of-governmentsand-social-partners-in-keeping-older-workers-in-the-labour-market, (accessed: 12.05.2016).

Stox Y. (2009), Belgium, [in:] N. ten Bokum, T. Flanagan, R. Sands, R. von Steinau-Steinrück (eds.), Age Discrimination Law in Europe, The Netherlands.

Szikra D. (2014), Democracy and Welfare in Hard Times: The Social Policy of the Orbán Government in Hungary between 2010 and 2014, "Journal of European Social Policy", vol. 24(5).

Sztanderska U. (2008), Przyczyny wczesnej dezaktywizacji zawodowej i emerytalnej osób ubezpieczonych w ZUS, [in:] Dezaktywizacja osób w wieku okołoemerytalnym. Raport z badań, Warszawa.

Szubert W. (1987), Ubezpieczenie społeczne. Zarys systemu, Warszawa.

Szukalski P. (2009), Ageizm na polskim rynku pracy, [in:] R. Horodeński, C. Sadowska-Snarska (eds.), Gospodarowanie zasobami pracy na początku XXI wieku. Aspekty makroekonomiczne i regionalne, Instytut Pracy i Spraw Socjalnych, Warszawa-Białystok.

Szukalski P. (2014), Ludzie bardzo starzy - niewidoczna grupa docelowa polityki społecznej?, "Studia Demograficzne”, vol. 2 (166), available at: http://dspace.uni.lodz.pl/xmlui/bitstream/handle/11089/11159/SD\%202014-2_Szukalski.pdf?sequence=1\&isAllowed=y (accessed: 1.06.2017).

Szukalski P. (2014), Zagrożenia dla aktywności osób starszych na rynku pracy w Polsce, [in:] P.Szukalski, B. Szatur-Jaworska (eds.), Aktywne starzenie się - Przeciwdziałanie barierom, Łódź.

Szukalski P.(2012), Trzy kolory: srebrny. Co to takiego silver economy?, "Polityka Społeczna”, no. 5-6.

Szylko-Skoczny M. (2004), Polityka społeczna wobec bezrobocia w Trzeciej Rzeczypospolitej, Warszawa.

Tamutienö I., Klercq J., Joosten J. (2009), Vyresnio amžiaus moterų ir vyrų lankstaus darbo metodai ir praktinis taikymas, vši „,socializacijos ir darbinio mokymo centras“ igyvendinamo projekto „socialinę riziką ir socialinę atskirtị patiriančių asmenų integracija ị darbo rinką taikant lankstaus darbo modelị ${ }^{\prime \prime}, \mathrm{nr} . \operatorname{vpl}(1.3(\operatorname{sadm}(02$ (k(01(020, Vilnius, available at: http://www.sidmc.org/ project_020/wp-content/uploads/IV_vyresni_zmones_santrauka.pdf.

Taylor P. (ed.), (2008), Ageing Labour Forces. Promises and Prospects, Cheltenham, UK-Northampton, Massachusetts, USA.

UN Economic Commission for Europe (2014), European Commission, Active Ageing index for 28 European Countries, November, http://www.unece.org/fileadmin/DAM/pau/age/WG7/Documents/Policy_Brief_AAI_for_EG_v2.pdf, (accessed: January 2016).

UNECE (2012), National Report. The Situation of Older People in Slovakia. Combating Poverty, available at: https://www.unece.org/fileadmin/DAM/pau/age/country_rpts/SVK_report.pdf, (accessed: September 2017). 
UNECE (2014), AAI 2014, Active Ageing Index for 28 European Countries, November, http://www. unece.org/fileadmin/DAM/pau/age/WG7/Documents/Policy_Brief_AAI_for_EG_v2.pdf, (accessed: September 2017).

Urbaniak B. (2013), Podstawowe charakterystyki zatrudnienia kobiet i mężczyzn w wieku 45/50+, [in:] E. Kryńska, J. Krzyszkowski, B. Urbaniak, J. Wiktorowicz (eds.), Diagnoza obecnej sytuacji kobiet i mężczyzn 50+ na rynku pracy w Polsce. Raport końcowy, Łódź 2013.

Urbaniak B. (2013), Sytuacja zawodowa kobiet i mężczyzn w wieku 45/50+, [in:] E. Kryńska, J. Krzyszkowski, B. Urbaniak, J. Wiktorowicz (eds.),, Diagnoza obecnej sytuacji kobiet i mężczyzn 50+ na rynku pracy w Polsce. Raport końcowy, Łódź.

Uścińska G. (2005), Europejskie standardy zabezpieczenia społecznego a wspótczesne rozwiązania polskie, Warszawa.

Vagač L. (2012), European Employment Observatory, EEO Review: Employment Policies to Promote Active Ageing, Slovakia, February, available at: www.ec.europa.eu/social/BlobServlet?docId=12 258\&langId=en, (accessed: September 2017).

Van Bael \& Bellis (eds.) (2003), Business Law Guide to Belgium. The Hague

van het Kaar R., Tros F. (2013), The Netherlands: The Role of Governments and Social Partners in Keeping Older Workers in the Labour Market, available at: https://www.eurofound.europa. eu/observatories/eurwork/comparative-information/role-of-governments-and-social-partnersin-keeping-older-workers-in-the-labour-market (accessed: 2.06.2013).

Van Looy B., Kovalenko M., Mortelmans D., de Preter H. (2014), Working Hour-reduction in the Move to Full Retirement: How Does this Affect Retirement Preferences of 50+ Individuals in Flanders?, Leuven-Antwerpen.

Vidovićová L. (2013), Extending Working Life and Active Impact in the Czech Republic, http://mopact. group.shef.ac.uk/wp-content/uploads/2013/10/Country-report-Czech-Republic.pdf, (accessed: September 2017).

Vidovićová L. (2014), Conceptual Framework of the Active Ageing Policies in Employment in Czech Republic, “CASE Research Paper”, no. 469, https://papers.ssrn.com/sol3/papers.cfm?abstract_ id=2406880, (accessed: September 2017).

Vogel S. (2008), Agreement on Retirement in Metal and Electrical Industry, Dublin, http://www.eurofound.europa.eu/printpdf/observatories/eurwork/articles/agreement-on-partial-retirementin-metal-and-electrical-industry, (accessed: 12.05.2016).

Vogel S. (2009), Young Workers to Substitute for Older Employees, http://www.eurofound.europa.eu/ observatories/eurwork/articles/young-workers-to-substitute-for-older-employees, (accessed: 12.05.2016).

Vogel S. (2012), Germany: Social Partners Involvment in Unemployment Benefit Regimes, Dublin, http://www.eurofound.europa.eu/observatories/eurwork/comparative-information/nationalcontributions/germany/germany-social-partners-involvement-in-unemployment-benefit-regimes, (accessed: 13.07.2016).

Von Steinau-Steinrück R., Vernuft C. (2009), Germany, [in:] N. ten Bokum, T. Flanagan, R.Sands, R. von Steinau-Steinrück (eds.), Age Discrimination Law in Europe, The Netherlands.

Waas B. (2010), Labour Policy and Fixed-Term Employment Contracts in Germany, [in:] Labour Policy on Fixed-term Employment Contracts, Comparative Labour Law Seminar, Tokyo. 
Wasilewska A., Rogala H. (2012), Programy specjalne - szansa, która czeka na wykorzystanie, "Służba Pracownicza", no. 3.

Węgierski portal prac publicznych (Közfoglalkoztatasi Portal), Information on the current status of Public Work Scheme (PWS) in Hungary, http://kozfoglalkoztatas.kormany.hu/ download/8/3a/51000/Information\%20on\%20the\%20current\%20status\%20of\%20Public\%20 Work\%20Scheme\%20(PWS)\%20in\%20Hungary.pdf, (accessed: 14.06.2017).

WHO (2015), World Report on Ageing and Health, Luxemburg: WHO, available at: http://apps.who. int/iris/bitstream/10665/186463/1/9789240694811_eng.pdf?ua=1 (accessed:1.06.2017).

WHO (2016), The Global Strategy and Action Plan on Ageing and Health Considered and Adopted by the WHA, Multisectoral Action for a Life Course Approach to Healthy Ageing: Draft Global Strategy and Plan of Action on Ageing and Health, Document A69/17, available at: http://apps. who.int/gb/ebwha/pdf_files/WHA69/A69_17-en.pdf.

Wiktorowicz J. (2013), Streszczenie, [in:] E. Kryńska, J. Krzyszkowski, B. Urbaniak, J. Wiktorowicz (eds.),, Diagnoza obecnej sytuacji kobiet i mężczyzn 50+ na rynku pracy w Polsce. Raport końcowy, Łódź.

Wiśniewski Z. (1999), Kierunki i skutki deregulacji rynku pracy w krajach Unii Europejskiej, Toruń.

Włodarczyk M. (2016), Komentarz do art. 36-36a, [in:] Z. Góral (ed.), Ustawa o promocji zatrudnienia i instytucjach rynku pracy. Komentarz, ed. II, Warszawa.

Włodarczyk M., Paluszkiewicz M. (2011), Formy prawne wyrównywania szans osób 50+/45+na rynku pracy w Polsce, [in:] B. Urbaniak, J. Wiktorowicz (eds.), Raport z analizy programów skierowanych do osób 50+ zrealizowanych $w$ Polsce w latach 2004-2009, Łódź.

Wojewódzki Urząd Pracy w Łodzi (2014), Informacja z realizacji Regionalnego Planu Działań na rzecz Zatrudnienia w województwie łódzkim w 2013 r., Łódź.

Wolff J., Stephan G. (2013), Subsidized Work before and after the German Hartz Reforms: Design of Major Schemes, Evaluation Results and Lessons Learnt, "IZA Journal of Labor Policy", vol. 2:16.

Wratny J. (2016), Rada Dialogu Społecznego. Czy jeszcze instytucja zbiorowego prawa pracy?, "Praca i Zabezpieczenie Społeczne", no. 10.

Wrocławska T. (2015), Idea międzypokoleniowego podziału pracy jako kryterium obowiązkowego przejścia na emeryturę w świetle stanowiska Trybunału Sprawiedliwości UE, [in:] T. BińczyckaMajewska, M. Włodarczyk (eds.), Wspótczesne problem prawa emerytalnego, Warszawa.

Wrocławska T. (2015), Kodeksowa szczególna ochrona trwałości stosunku pracy pracowników w wieku przedemerytalnym, [in:] Z. Góral, M. Mielczarek (eds.), 40 lat Kodeksu pracy, Warszawa.

Wrocławska T. (2015), Non-discrimination Principle and the Need for Special Treatment of Older Employees (Considerations Based on Polish Statutory Regulations), Wei International Academic Conference Proceedings, available at: https://www.westeastinstitute.com/wp-content/uploads/2016/05/Tatiana-Wrocławska-1.pdf, (accessed: September 2017).

Wrocławska T. (2016), Komentarz do rozdziału 11, art. 104b, [in:] Z. Góral (ed.), Ustawa o promocji zatrudnienia i instytucjach rynku pracy. Komentarz, ed. II, Warszawa.

Wrocławska T. (2016), Uwagi na tle wyroku SN z dnia 18 grudnia 2014 r., II PK 50/145, "GdańskoŁódzkie Roczniki Prawa Pracy i Prawa Socjalnego", vol. 6.

Wrocławska T. (2017), Glosa do wyroku Sądu Najwyższego z dnia 16 lutego 2017 r., II PK 375/15, “Orzecznictwo Sądów Polskich”, no. 11. 
Wrocławska T. (2017), The Analyses of the Legal Measures Taken to Combat Unemployment (to Boost Employability) among Older People According to the Last Amendments of the Polish Law on Employment Promotion and Labour Market Institutions, [in:] T. Davulis, P. Lang (eds.), Labour Law Reforms in Eastern and Western Europe, Brussels.

Wrocławska T. (2017), Umowy na czas określony a zatrudnienie osób starszych, [in:] M. Mędrala (ed.), Terminowe umowy o prace, Warszawa.

Wrocławska T., (2015) Employment Permanence (Stability) of Employment Relationship of Older Employees - Analysis of Changes, [in:] Developments in Labour Law from a Comparative Perspective, Łódź.

Wrocławska T., Protection and Guarantees for Older Employees with Chronic Diseases (Cancer) through Labour Legislation in Poland - an article was sent to publisher.

Wrocławska T., The Right to Choose or Having no Choice: Retirement or Employment. Dilemmas Related to Old Age (Remarks Based on Polish Legal Regulations), "Economic and Environmental Studies" - an article was sent to publisher.

Zabarauskaitė R., Blažienė I. (2014), Lithuania: Role of social dialogue in industrial policies, https:// www.eurofound.europa.eu/observatories/eurwork/comparative-information/national-contributions/lithuania/lithuania-role-of-social-dialogue-in-industrial-policie, (accessed: January 2016).

Zbyszewska A., Sustainability, Active Aging through Employment and the Question of Care in Poland. A Social Reproduction Perspective, 9-11, draft paper, available at: https://ecpr.eu/Filestore/PaperProposal/a31ae2ac-bedd-4590-85c8-897bce0b5e01.pdf (accessed: 1.06.2017).

Zgliczyński W. S. (2013), Wynagrodzenia w Polsce, “Infos”, no. 22 (159).

Zwick T. (2008), The Employment Consequences of Seniority Wages, “ZEW Discussion Paper”, no. 08-039. 